\title{
EA
}

DOE/EIA-0478(96)

Energy Information Administration

\section{Uranium Industry Annual 1996}

April 1997 \section{RECEIVED
MAY 05 S \\ 0.851}
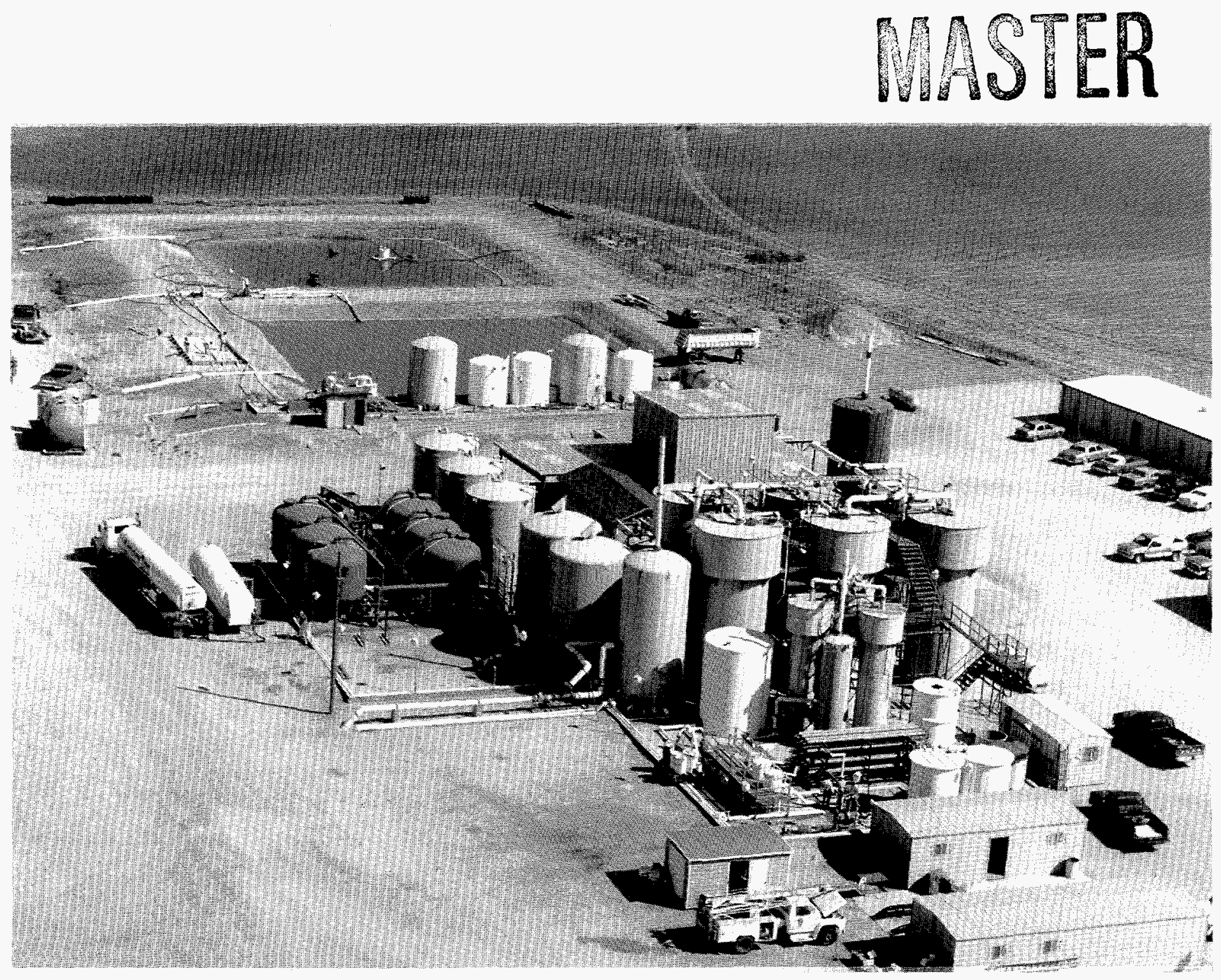

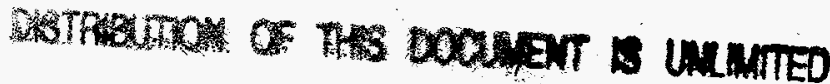




\section{HOW TO OBTAIN EIA PRODUCTS AND SERVICES}

For further information on any of the following services, or for answers to energy information questions, please contact EIA's National Energy Information Center:

\author{
National Energy Information Center (NEIC) \\ Energy Information Administration \\ Forrestal Building, Room 1F-048 \\ Washington, DC 20585
}

(202) $586-8800$

(202) 586-0727 (fax)

TTY: (202) 586-1181

E-mail: infoctr@eia.doe.gov

\section{Electronic Products and Services}

EIA's Internet Site Services offer nearly all EIA publications. Users can view and download selected pages or entire reports, search for information, download EIA data and analysis applications, and find out about new EIA information products and services.

World Wide Web: http://www.eia.doe.gov

Gopher: gopher://gopher.eia.doe.gov

FTP: ftp://ftp.eia.doe.gov

EIA also offers a listserve service for EIA press releases and other short documents. Sign up on the EIA World Wide Web site.

EIA's CD-ROM, Energy InfoDisc, contains most EIA publications, several databases, and an energy forecasting model. The Energy InfoDisc, produced quarterly, is available for a fee from STAT-USA, Department of Commerce, 1-800-STAT-USA.

The Comprehensive Oil and Gas Information Source (COGIS), a bulletin board service, contains data files from most of EIA's oil- and gas-related reports. It is available for a fee from STAT-USA, on 1-800-STAT-USA.

EIA's Electronic Publishing System (EPUB) bulletin board contains data files, directories, and forecasts from most EIA reports. It can be accessed free of charge by dialing (202) 586-2557.

Many of EIA's data files and modeling programs are available for sale on diskette, tape, or cartridge, through either the National Technical Information Service or the Office of Scientific and Technical Information, Department of Energy. Contact NEIC for information on specific products, sources, and media, and ordering instructions.

\section{Printed Publications}

EIA directories are available free of charge from NEIC. Recent EIA periodicals and other publications are available from the Government Printing Office. Older reports are available from the National Technical Information Service:

\section{Superintendent of Documents}

U.S. Government Printing Office

P.O. Box 371954

Pittsburgh, PA 15250-7954

(202) 512-1800; (202)-512-2250 (fax)
National Technical Information Service

U.S. Department of Commerce

5285 Port Royal Road

Springfield, VA 22161

(703) 487-4650; (703) 321-8547 (fax)

Cover Photo: $\quad$ Uranium Resource's Kingsville Dome ISL plant located in Kleberg County, Texas, which shows the plant complex in the lower area of the photo, and the evaporation ponds in the upper portion of the photograph. (credit: Uranium Resources, Inc.)

Released for Printing: April 22, 1997

GPO Stock No:: 061-003-00994-8 
DOE/EIA-0478(96)

Distribution Category UC-950

\title{
Uranium Industry Annual 1996
}

\author{
April 1997
}

Energy Information Administration

Office of Coal, Nuclear, Electric and Alternate Fuels

U.S. Department of Energy

Washington, DC 20585

This report was prepared by the Energy Information Administration, the independent statistical and analytical agency within the Department of Energy. The information contained herein should not be construed as advocating or reflecting any policy position of the Department of Energy or any other organization. 


\section{Contacts}

This report was prepared by the Energy Information Administration (EIA), Office of Coal, Nuclear, Electric and Alternate Fuels. General information about this document may be obtained from the National Energy Information Center (202/586-8800), or John C. Geidl (202/426-1200), Director of the Office of Coal, Nuclear, Electric and Alternate Fuels, and Robert M. Schnapp (202/426-1211), Director of the Analysis and Systems Division. Technical information about this report may be obtained from $\mathrm{Dr}$. $\mathrm{Z}$. D. Nikodem (202/426-1179), Chief of the Nuclear Fuel Cycle Branch.

Specific questions regarding the various sections of the report should be addressed to the following staff personnel and/or section authors:
Exploration, production, employment, and marketing activities:

Douglas Bonnar on (202) 426-1249; or email address: dbonnar@eia.doe.gov

Feature article, reserves and resources:

Taesin Chung on (202) 426-1128;

or email address: tchung @eia.doe.gov

Survey methodology and operations:

Charles Johnson on (202) 426-1178;

or email address: cjohnson@eia.doe.gov. 


\section{DISCLAMMER}

Portions of this document may be illegible in electronic image products. Images are produced from the best available original document. 


\section{DISCLAIMER}

This report was prepared as an account of work sponsored by an agency of the United States Government. Neither the United States Government nor any agency thereof, nor any of their employees, make any warranty, express or implied, or assumes any legal liability or responsibility for the accuracy, completeness, or usefulness of any information, apparatus, product, or process disclosed, or represents that its use would not infringe privately owned rights. Reference herein to any specific commercial product, process, or service by trade name, trademark, manufacturer, or otherwise does not necessarily constitute or imply its endorsement, recommendation, or favoring by the United States Government or any agency thereof. The views and opinions of authors expressed herein do not necessarily state or reflect those of the United States Government or any agency thereof. 


\section{Preface}

The Uranium Industry Annual 1996 (UIA 1996) provides current statistical data on the U.S. uranium industry's activities relating to uranium raw materials and uranium marketing. The UIA 1996 is prepared for use by the Congress, Federal and State agencies, the uranium and nuclear electric utility industries, and the public. It contains data for the period 1987 through 2006 as collected on the Form EIA-858, "Uranium Industry Annual Survey."

Data collected on the "Uranium Industry Annual Survey" provide a comprehensive statistical characterization of the industry's activities for the survey year and also include some information about industry's plans and commitments for the near-term future. Where aggregate data are presented in the UIA 1996, care has been taken to protect the confidentiality of company-specific information while still conveying accurate and complete statistical data.

The legal authority for Form EIA-858, "Uranium Industry Annual Survey," comes from Section $13 \mathrm{~b}$ of the Federal Energy Administration Act of 1974 (15 U.S.C. 2210b).

On October 24, 1992, the Congress enacted the Energy Policy Act of 1992 (EPACT 1992), Public Law 102-486. This law provides under Subtitle B, 42 USC $\$ 2296 \mathrm{~b}-4$, Sec. 1015, that:

". . the owner or operator of any civilian nuclear power reactor shall report to the Secretary (of Energy), acting through the Administrator of the Energy Information Administration, for activities of the previous fiscal year-
(1) the country of origin and the seller of any uranium or enriched uranium purchased or imported into the United States either directly or indirectly by such owner or operator; and

(2) the country of origin and the seller of any enrichment services purchased by such owner or operator."

The information is required to be made available to the Congress annually. In previous years, this information was provided in a separate issue entitled Uranium Purchases Report, that is no longer being produced. The data is now contained in Chapter 2 (Tables 12, 22, 23, and 25) of this report.

Data on uranium raw materials activities for 1987 through 1996 including exploration activities and expenditures, EIA-estimated reserves, mine production of uranium, production of uranium concentrate, and industry employment are presented in Chapter 1. Data on uranium marketing activities for 1994 through 2006, including purchases of uranium and enrichment services, enrichment feed deliveries, uranium fuel assemblies, filled and unfilled market requirements, uranium imports and exports, and uranium inventories are shown in Chapter 2.

The methodology used in the 1996 survey, including data edit and analysis, is described in Appendix A. The methodologies for estimation of resources and reserves are described in Appendix B. A list of respondents to the "Uranium Industry Annual Survey" is provided in Appendix C. For the readers convenience, metric versions of selected tables from Chapters 1 and 2 are presented in Appendix D along with the standard conversion factors used. A glossary of technical terms is at the end of the report. 



\section{Contents}

\section{Page}

Feature Article: The Role of Thorium in Nuclear Energy

ix

Highlights xix

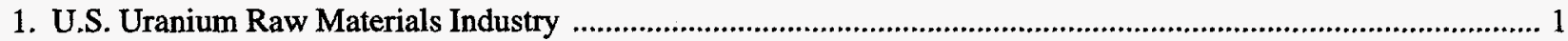

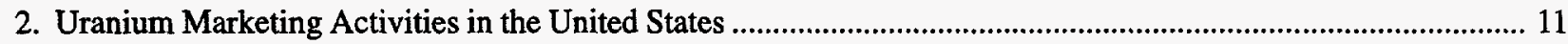

\section{Appendices}

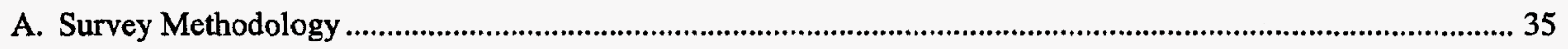

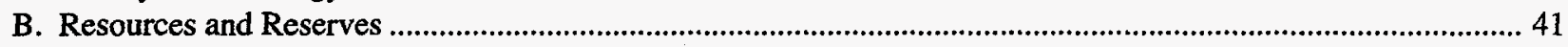

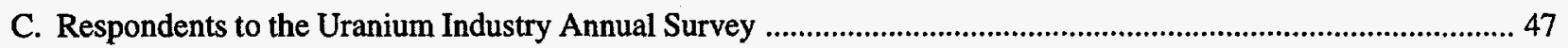

D. U.S. Customary Units of Measurement, International System of Units (SI), and

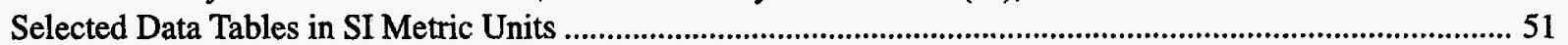

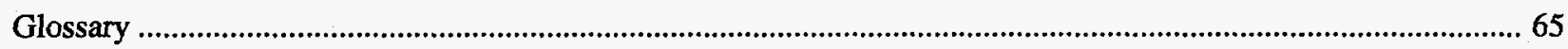


Table 1. U.S. Uranium Land and Surface Drilling Activities, 1987-1996

Table 2. Expenditures for Exploration and Development of Uranium in the United States, 1987-1996

Table 3. Forward-Cost Uranium Reserves by Mining Method, 1996 ............................................................. 7

Table 4. U.S. Uranium Mine Production and Number of Mines and Sources, 1987-1996 ................................. 7

Table 5. U.S. Uranium Concentrate Processing Operations, 1987-1996 …...................................................... 8

Table 6. Operating Status of Conventional Uranium Mills, End of the Year, 1993-1996 _................................. 9

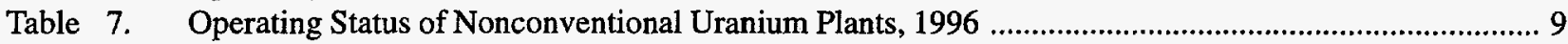

Table 8. Employment in the U.S. Uranium Industry by Category, 1987-1996 ................................................... 10

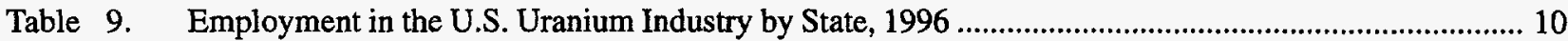

Table 10. U.S. Utilities Contracted Uranium by Supplier, Transaction Type, and Delivery

Year, 1994-1996

Table 11. U.S. Utilities Contracted Uranium by Transaction Type and Delivery Year, 1994-1996

Table 12. U.S. Utilities Purchases of Uranium by Origin Country and Delivery Year, 1994-1996

Table 13. U.S. Utilities Contracted Uranium by Transaction Type, Material Type, and

Delivery Year, 1996

Table 14. Average Price and Quantity for Purchases of Uranium by U.S. Utilities by Pricing Mechanisms and Delivery Year, 1994-1996.

Table 15. Price Distributions of Uranium Purchases by U.S. Utilities by Delivery Year, 1994-1996

Table 16. U.S. Utility Uranium Purchases by Contract Type and Material Type, 1996

Table 17. Contracts Signed by U.S. Utilities in 1996 by Contract Type and Delivery Year 1996

Table 18.

U.S. Utilities Contracted Purchases of Uranium, Signed in 1996, by Delivery Year, 1997-2006 ......... 24

Table 19. U.S. Utilities Contracted Purchases of Uranium from Suppliers, in Effect at the

End of 1996, by Delivery Year, 1997-2006

Table 20.

Unfilled Uranium Requirements of U.S. Utilities, 1997-2006.

Table 21

Anticipated Uranium Market Requirements of U.S. Utilities, 1997-2006, as of

December 31, 1996

Table 22. U.S. Utilities Deliveries of Uranium Feed by Enrichment Country and Delivery

Year, 1994-1996

Table 23. U.S. Utilities Deliveries of Uranium Feed for Enrichment by Origin Country and Delivery Year, 1994-1996

Table 24. Shipments of Uranium by U.S. Utilities to Domestic and Foreign Enrichment Suppliers, 1997-2006

Table 25. U.S. Utilities Purchases of Enrichment Services by Country and Delivery Year, 1994-1996

Table 26. U.S. Utilities Purchases of Enrichment Services by Contract Type in

Delivery Year 1996

Table 27. Uranium in Fuel Assemblies Loaded into U.S. Commercial Nuclear Reactors by

Year, 1994-1996

Table 28.

Imports of Uranium by U.S. Suppliers, U.S. Utilities and Delivery Year, 1994-1996

Table 29.

U.S. Brokers and Traders Purchases of Uranium by Material Origin, Supplier, and Delivery Year, 1994-1996

Table 30. Uranium Exports to Foreign Suppliers and Utilities by Origin and Delivery Year, 1994-1996.

Table 31.

Table 32.

Table 33.

Table A1.

Inventories of Natural and Enriched Uranium as of End of Year, 1994-1996

Commercial Uranium Inventories by Type and Location at End of Year, 1994-1996 ........................... 31

Commercial Uranium Inventories by Type and Owner at End of Year, 1994-1996 ............................... 31

Table B1. U.S. Potential Uranium Resources by Forward-Cost Category and Resource Class, 1987-1996 
Table B2. U.S. Potential Uranium Resources by Forward-Cost Category and

Resource Region, 1996

Table B3. U.S. Uranium Reserves by Forward-Cost Category, 1987-1996 ..................................................... 44

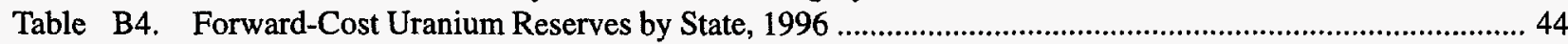

Table C1. Respondents to the 1996 Uranium Industry Annual Survey ...............................................................4 47

Table D1. Conversion Factors for U.S. Customary Units and SI Metric Units of Measurement ..........................51

Table D2. U.S. Uranium Land and Surface Drilling Activities, 1987-1996 .................................................5 53

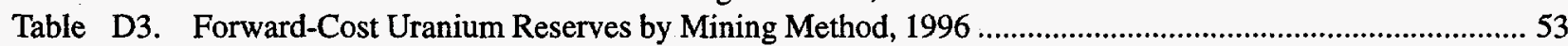

Table D4. U.S. Uranium Mine Production and Number of Mines and Sources, 1987-1996 _.............................. 54

Table D5. U.S. Uranium Concentrate Processing Operations, 1987-1996 ........................................................... 55

Table D6. U.S. Utilities Contracted Uranium by Supplier, Transaction Type, and Delivery Year, 1994-1996

Table D7. U.S. Utilities Contracted Uranium by Transaction Type and Delivery Year, 1994-1996

Table D8. U.S. Utilities Purchases of Uranium by Origin Country and Delivery Year, 1994-1996

Table D9. Average Price and Quantity for Purchases of Uranium by U.S. Utilities by

Pricing Mechanisms and Delivery Year, 1994-1996.

Table D10. U.S. Utilities Contracted Purchases of Uranium from Suppliers, in Effect at the End of 1996, by Delivery Year, 1997-2006

Table D11. Anticipated Uranium Market Requirements of U.S. Utilities, 1997-2006, as of December 31, 1996

Table D12. U.S. Utilities Deliveries of Uranium Feed by Enrichment Country and Delivery Year, 1994-1996

Table D13. Uranium in Fuel Assemblies Loaded into U.S. Commercial Nuclear Reactors by Year, 1994-1996

Table D14. Imports of Uranium by U.S. Suppliers, U.S. Utilities and Delivery Year, 1994-1996

Table D15. U.S. Brokers and Traders Purchases of Uranium by Material Origin, Supplier, and Delivery Year, 1994-1996

Table D16. Uranium Exports to Foreign Suppliers and Utilities by Origin and

Delivery Year, 1994-1996

Table D17. Inventories of Natural and Enriched Uranium as of End of Year, 1994-1996

Figures

Figure 1. Exploration and Development Expenditures, 1986-1996 ................................................................... 3

Figure 2. U.S. Uranium Mine Production, 1987-1996 ................................................................................. 3

Figure 3. Uranium Concentrate Production, 1987-1996 ........................................................................................ 3

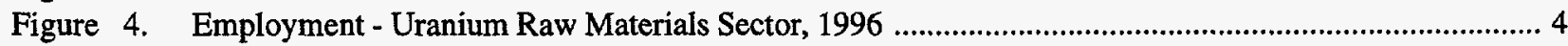

Figure 5. U.S. Uranium Exploration and Development Surface Drilling Cost, 1987-1996 ............................... 4

Figure 6. U.S. Uranium Concentrate Production and Shipments, 1987-1996 ...................................................... 4

Figure 7. Major U.S. Uranium Reserve Areas and Status of Mills and Plants, 1996 ......................................... 5

Figure 8. Uranium Marketing Activity During 1996 .................................................................................. 14

Figure 9. Quantity of U.S. Utilities Purchases of Uranium by Supplier and Delivery Year, 1994-1996 .............. 15

Figure 10. Weighted-Average Price of U.S. Utilities Purchases of Uranium by Supplier and Delivery Year,

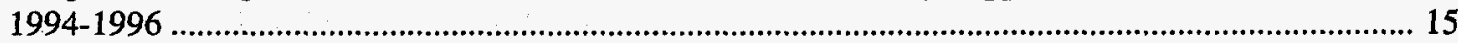

Figure 11. Quantity of U.S. Utilities Purchases of Uranium by Origin and Delivery Year, 1994-1996 .................. 15

Figure 12. U.S. Utilities Purchases of Uranium by Selected Country Origin and Delivery Year, 1994-1996 ........ 16

Figure 13. U.S. Utilities Purchases of Uranium by Material Type and Delivery Year, 1994-1996 ........................ 16

Figure 14. U.S. Utilities Purchases of Uranium by Contract Type and Material Type, 1996 Deliveries ................ 16 
Figure 15. U.S. Utilities Contracted Purchases of Uranium by Supplier, Firm Deliveries, and Delivery Year, 1997-2006

Figure 16. U.S. Utilities Annual Unfilled Requirements, 1997-2005

Figure 17. Anticipated Uranium Market Requirements of U.S. Utilities, 1997-2006 ......................................... 17

Figure 18. Uranium in Fuel Assemblies Loaded into U.S. Commercial Nuclear Reactors by Year, 1994-1996.

Figure 19. U.S. Brokers and Traders Purchases of Uranium by Quantity, Weighted-Average Price, and Delivery Year, 1994-1996

Figure 20. Foreign Sales (Exports) of Uranium by Quantity, Weighted-Average Price, and Delivery Year, 1994-1996

Figure 21. Commercial Uranium Inventories at End of the Year, 1994-1996.

Figure 22. U.S. Utilities Uranium Inventories at End of the Year, 1994-1996

Figure B1. Comparison of Historical and Current U.S. and NEA/IAEA Classification

Nomenclature for Uranium Resources

Figure B2. Uranium Resource Regions of the United States 


\title{
The Role of Thorium in Nuclear Energy
}

\author{
by \\ Taesin Chung
}

Thorium, like uranium, is a nuclear fuel, but the use of thorium fuel, unlike the use of uranium, has nearly been forgotten. While uranium technology in Light Water Reactors (LWR) has been demonstrated to be dependable for over 30 years and is well understood today, the use of thorium technology has lagged behind uranium's ever since the demise of the Fort St. Vrain commercial High Temperature GasCooled Reactor (HTGR) and the U.S. Government cancellation of the Clinch River Breeder Reactor research program.

The sustained lack of interest in thorium as a nuclear fuel has resulted in limited research efforts; very few data have been compiled in the United States on the subject and even fewer have been published in recent years. This article presents an historical overview of thorium activities in nuclear energy development and discusses the following related issues: (1) thorium mineral deposits, (2) reserves, (3) production, (4) commercial development of the thorium fueled reactor, (5) thorium fuel cycle, (6) government procurement, and (7) the environmental remediation of thorium sites.

\section{Thorium Raw Materials}

\section{Deposits}

Thorium is widely distributed in nature and is usually associated with uranium and rare-earth ${ }^{1}$ elements. Concentration of thorium ore occurs in the following three principal types of deposits: (1) vein deposits, (2) beach or stream placer deposits, ${ }^{2}$ and (3) carbonatites in igneous or metamorphic rocks (Figure 1).

The vein deposits of thorite $\left(\mathrm{ThSiO}_{4}\right)$, such as occur in the area of Lemhi Pass, Idaho, are the highest grade thorium mineral, containing about 25 to 63 percent thorium oxide $\left(\mathrm{ThO}_{2}\right)^{3}$ Although few vein type deposits have been developed thus far in the United States, high grade thorite is likely to be exploited in the event a large demand arises for domestic thorium. Most of the vein deposits are associated with quartzfeldspar iron-oxide. Other vein-type thorium minerals include thorianite and bastnaesite.

A substantial quantity of thorium also co-exists with uranium in Precambrian conglomerates, such as in the Elliot Lake area of Ontario, Canada. ${ }^{4}$ The conglomerate deposit in this region is also a potentially important source for the long-term supply of thorium in North America.

Monazite ((Ce,La,Y,Th) $\left.\mathrm{PO}_{4}\right)$, the most commercially exploited thorium mineral, contains up to about 12 percent thorium oxide. It is found mostly in the stream placer deposits in northern Idaho, the Carolinas, and the Pleistocene beach sands in Florida. Monazite generally forms along with heavy minerals like ilmenite, rutile, zircon, and sillimenite and is essentially an orthophosphate of thorium and rare-earths. Stream placer deposits of monazite-bearing crystalline rocks occurring in the Carolina Piedmont of the Southeastern Monazite Belt were the earliest domestic source of thorium but are smaller in size.

Bastnaesite ore is located in the Mountain Pass District of California. Rare-earth fluorocarbonate mineral and other carbonatite concentrate deposits can be found in the South Platte District of Colorado and the Barringer Hill District of Texas. This type of deposit consists of mostly low grade ores.

In an effort to assess up-to-date information on the extent of U.S. thorium supply capability, the Department of Energy (DOE) contracted with the U.S. Geological Survey (USGS) in 1977 to conduct a new evaluation of domestic thorium

\footnotetext{
1 Any of the abundant metallic elements of atomic number 57 through 71 .

2 A glacial or alluvial deposits of gravel or sand containing minerals.

3 Battelle Pacific Northwest Laboratory, "An Assessment of U.S. Domestic Capacity for Producing Reactor-Grade Thorium Oxide and Controlling Associated Wastes and Effluents," PNL-2593 (February 1978), p. 9.

4 Energy Information Administration, Comparison of Uranium Mill Tailings Reclamation in the United States and Canada (Washington, DC, July 1995).
} 


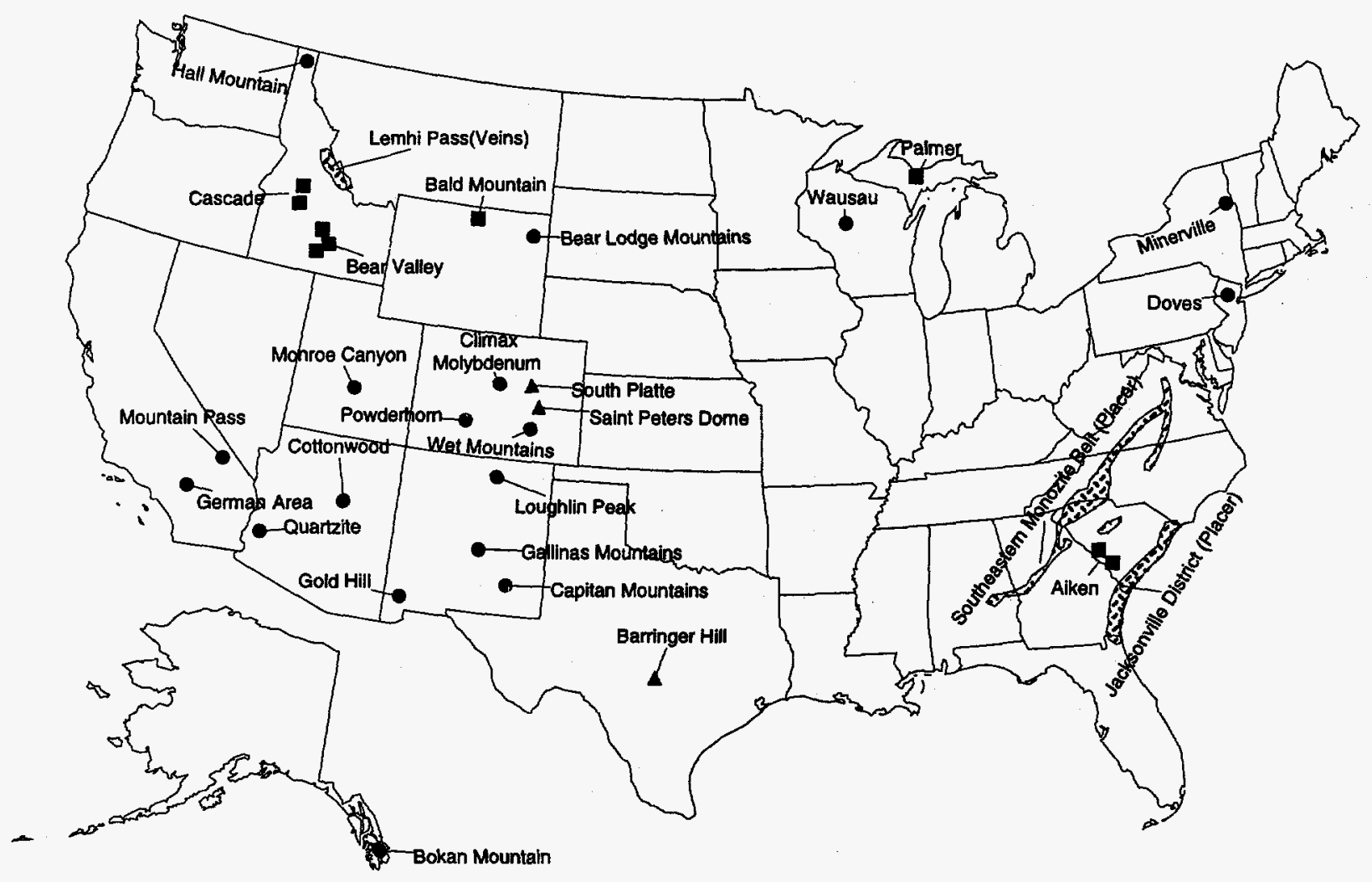

Source: A file document, Grand Junction Project Office, U.S. Department of Energy, Grand Junction, Colorado, 1979.

resources as part of the DOE's National Uranium Resource Evaluation (NURE) program that lasted from 1974 through 1983. In the early 1980s, the USGS estimated domestic thorium reserves at about 150,000 short tons and probable potential resources of over 300,000 short tons of thorium oxide $\left(\mathrm{ThO}_{2}\right.$ ) equivalent (Table 1) in the three principal types of deposits (Figure 1) that can be recovered at less than $\$ 15$ per pound ${ }^{5}$ of $\mathrm{ThO}_{2}$.

Subsequent to the USGS study, however, there has been little or no Government evaluation of thorium resources, development, or procurement, nor are any such programs being anticipated for the future in the United States.

\section{Production}

With the exception of some production in 1958 and 1959 from the vein deposit in the Wet Mountain District in Colorado, ${ }^{6}$ nearly all domestic thorium has been extracted from monazite or produced as a byproduct from the processing of monazite for rare-earths. However, because of low demand since the mid-1970s, the extractable thorium contained in monazite has remained mostly in the tailings sludge left from the recovery of rare-earth oxides. Monazite contains an average of 3 to 10 percent thorium oxide and 50 to 60 percent rare-earth oxides. ${ }^{7}$

5 The $\$ 15$ per pound figure is based on the "current dollar" at the time of estimation.

6 Vranesh and Raisch, Attorneys at Law, Boulder, Colorado, letters of June 21, 1983, June 25, 1986, and December 4, 1986, to the Division of Uranium Mill Tailings Project, U.S. Department of Energy.

7 National Lead Company of Ohio, Thorium Production Technology, prepared under contract with the U.S. Atomic Energy Commission (1958), pp. 15-16 and 53. 
Table 1. U.S. Thorium Reserves and Resources, by Type of Deposit (Short Tons at $\$ 15$ per Pound $\left.\mathrm{ThO}_{2}\right)^{\mathrm{a}}$

\begin{tabular}{cr|r}
\hline Type of Deposit & Reserves & Resources \\
\hline Veins ${ }^{b} \ldots \ldots \ldots \ldots \ldots \ldots$ & 129,100 & 312,890 \\
Placers & & \\
Stream $\ldots \ldots \ldots \ldots \ldots \ldots$ & 4,640 & 6,560 \\
Beach $\ldots \ldots \ldots \ldots \ldots \ldots$ & 15,800 & ${ }^{c} 5,120$ \\
Carbonatite $\ldots \ldots \ldots \ldots \ldots$ & 300 & 1,920 \\
& & \\
Total . . . . . . $\ldots \ldots \ldots$. & 149,870 & 326,490 \\
\hline
\end{tabular}

aThe $\$ 15$ per pound figure is based on "current dollars" at the time of estimation.

Includes Bokan Mountain, Alaska, resources.

'Like uranlum, thorium reserves and resources are estimated as forward cost basis and the reserves may be larger than the resources in the same cost category.

Note: Incremental totals are summarized from USGS Circulars 805 and 824.

Source: U.S. Department of Energy, Grand Junction Project Office, Grand Junction, Colorado, file document (May 1981).

Mining of monazite in placer deposits is usually carried out by bulldozers and front-end loaders, or suction dredging. Separation of monazite from other minerals is effected by a combination of magnetic, electrostatic, and gravity separation techniques. Hydrometallurgical processing of monazite is carried out either by sulfuric acid or caustic treatment, followed by separation of the rare earths and thorium by partial precipitation or leaching.

In 1994 , one thorium-bearing monazite mine was active in Green Cove Springs, Florida. ${ }^{8}$ It recovered the rare earth content as a byproduct during processing for titanium and zirconium minerals, but the mine ceased operation in $1995 .{ }^{\circ}$ The estimated world monazite concentrate production in 1994 was 17,610 short tons, a decrease of 38 percent from the 1993 level. Australia, followed by India, again were the leading countries in monazite concentrate production in 1994 (Table 2).

The 1994 domestic consumption of thorium oxide equivalent was 19 short tons. Non-nuclear uses accounted for essentially all of the total domestic consumption. All of the domestic uses (non-nuclear) of thorium compound were derived from either imports, company stocks, or Government stockpiles. As of January 1, 1994, the DOE inventory was 1,120 short tons of thorium oxide equivalent contained in ore concentrate, metal, and various compounds. The stocks of thorium nitrate in the National Defense Stockpile were 3,550 short tons. There were no stocks of thorium nitrate sold or shipped in 1994, although the National Defense Authorization Act (Public Law 103-160) authorized for disposal of the National Defense stocks classified as excess to the goal ( 300 short tons) ${ }^{10}$

\section{Non-Nuclear Use}

Thorium fluoride is used in the manufacture of carbon arc lamps for movie projectors and searchlights to provide a highintensity light. Thorium metal has a high melting point $(3,100$ degrees $F),{ }^{11}$ a property which contributes to its being used in high-strength alloys and refractory applications like ceramic parts and crucibles. Thorium nitrate had long been used in the manufacture of mantles for incandescent lanterns, including natural gas lamps and oil lamps. Thoriated mantles, however, are not being produced currently in the United States due to the development of a suitable thorium-free substitute. Thorium nitrate also is used to produce thoriated tungsten welding electrodes. Thorium is used in various types of electron emitting-tubes, high-refractivity glass, and metallurgical applications, such as magnesium or nickel alloys.

\section{Thorium as a Nuclear Fuel}

\section{Commercial Development}

Although natural thorium cannot be used to produce a nuclear chain reaction by itself, it can, under irradiation, be converted into the fissile fuel, uranium $\left({ }^{233} \mathrm{U}\right)$. Therefore, thorium $\left({ }^{232} \mathrm{Th}\right)$ is consequently of potential use in nuclear reactors. Use of thorium in addition to uranium would expand the nuclear fuel supply base. Further, advanced converter reactors using thorium would not generate plutonium. Plutonium produced during nuclear power generation and its recycling raises nuclear proliferation concerns.

For these reasons, there were many studies in the 1960s and 1970 s to determine the feasibility of using thorium in nuclear power reactors. Studies were focused toward potential applications on HTGR, Light Water Breeder Reactor (LWBR), and Gas-Cooled Fast Breeder Reactor (GCFR). Also, the U.S. Government considered a modified Canadian Deuterium Uranium (CANDU) reactor capable of consuming thorium. In the United States, the best known reactor designs using thorium

8 The 1994 production quantity for this mine is withheld to avoid disclosing company proprietary data.

9 Society of Mining Engineers, American Institute of Mining, Metallurgical and Petroleum Engineers, Mining Engineering (Littleton, Colorado, June 1996), p. 35.

${ }^{10}$ U.S. Bureau of Mines, Thorium - Annual Review (Washington, DC, July 1995), pp. 1-3. The U.S. Bureau of Mines was abolished in January 1996.

${ }^{11}$ National Lead Company of Ohio, Thorium Production Technology, prepared under contract with the U.S. Atomic Energy Commission (1958), pp. 15-16. 
Table 2. World Monazite Concentrate Production, by Country (Short Tons, Gross Weight)

\begin{tabular}{|c|c|c|c|c|c|}
\hline Country ${ }^{a}$ & 1990 & 1991 & 1992 & 1993 & $1994^{b}$ \\
\hline Australia $^{b}$ & 12,130 & 7,720 & 6,610 & 17,640 & 6,610 \\
\hline Brazil .... & 1,830 & 1,440 & 1,540 & 1,540 & 1,540 \\
\hline China ........ & 2,620 & 1,310 & $b_{1,980}$ & ${ }^{b} 1,980$ & 1,980 \\
\hline India ${ }^{b} \ldots \ldots$ & 4,960 & 4,410 & 4,410 & 5,070 & 5,070 \\
\hline Malaysia ....... & 3,660 & 2,280 & 860 & 450 & 470 \\
\hline South Africa & 1,460 & ${ }^{c} 1,430$ & 1,430 & 1,430 & 1,430 \\
\hline Sri Lanka ${ }^{b} . .$. . & 220 & 220 & 220 & 220 & 220 \\
\hline Thailand ... & 420 & ${ }^{b} 440$ & 100 & 240 & 220 \\
\hline United States & $w$ & $w$ & $w$ & $w$ & $w$ \\
\hline Zaire $^{b}$ & 140 & 130 & 60 & 60 & 70 \\
\hline Total $^{d} \ldots \ldots \ldots \ldots \ldots \ldots \ldots \ldots \ldots$ & 27,440 & 19,380 & 17,210 & 28,630 & 17,610 \\
\hline
\end{tabular}

an addition to the countries listed, Indonesia, North Korea, Republic of Korea, Nigeria, and the former USSR may produce monazite, but output, if any, is not reported quantitatively, and available general information is inadequate for formulation of reliable estimates of output levels.

Estimated.

Reported figure.

"The "Total" does not include the U.S. production.

$W=$ Withheld to avoid disclosure of company-specific data.

Notes: All data cells are rounded to the nearest ten short tons.

Source: U.S. Bureau of Mines, Thorium - Annual Review 1994 (Washington, DC, July 1995), p. 4. (The U.S. Bureau of Mines was abolished in January 1996).

in the reactor core were the LWBR, designed by the Bettis Atomic Power Laboratory at Shippingport, Pennsylvania, and the HTGR, developed by the General Atomic Corporation in San Diego, California.

The only U.S. commercial thorium/uranium fueled HTGR was the Fort St. Vrain reactor near Platteville, Colorado. The reactor, with a capacity of $330 \mathrm{MWe}$, owned by the Public Service Company of Colorado (PSC), began full operation in early 1979. The operation of the Fort St. Vrain reactor, the full-scale commercial HTGR, however, became unsuccessful due to a combination of economic factors and lingering mechanical problems that resulted in over two years of delays in starting, followed by intermittent operations with a persistently low capacity factor.

With the development of large uranium reserves in North America in the 1970s and 1980s, followed by ample supplies of low-cost uranium, utilities were reluctant to invest in a new thorium-fueled reactor (HTGR), especially one that had not been operated under industrial conditions. Subsequently, all new HTGR orders previously placed were canceled. Eventually, the Fort St. Vrain power plant itself was permanently shutdown in 1989 , after a mere 10 years of operation.

In 1983, the U.S. Government canceled the Clinch River Breeder Reactor (375 MWe) program that would have required reprocessing plutonium. Since then, there have been few Government research efforts on the thorium fuel cycle technology and no commercial development of thorium-fueled reactors.

\section{Thorium Fuel Cycle}

The most common thorium nucleus, ${ }^{232} \mathrm{Th}$, consists of 90 protons and 142 neutrons. By absorbing a neutron, the ${ }^{232} \mathrm{Th}$ becomes ${ }^{233} \mathrm{Th}$, making it much less stable than it was before. Half the ${ }^{233} \mathrm{Th}$ will decay within 23 minutes by emitting one negative charge each (a beta particle). The loss of each negative charge in this fashion transforms one of the neutrons inside the affected nucleus into an additional proton. However, as soon as the number of protons in a nucleus changes, the atom is transformed into a completely different element called protactinium $\left({ }^{233} \mathrm{~Pa}\right)$. The ${ }^{233} \mathrm{~Pa}$ is only slightly more stable, having a half-life of 27 days. It goes through a second decay process, losing another electron and resulting in an atom containing 92 protons and only 141 neutrons called uranium-233 $\left({ }^{233} \mathrm{U}\right)$.

The ${ }^{233} \mathrm{U}$, which has a half-life of 163,000 years, can fission when struck by a neutron, and part of its mass is transformed directly into energy (Figure 2). In other words, it can support a chain reaction in a nuclear reactor. From the standpoint of nuclear energy, therefore, the thorium role could be significant. 


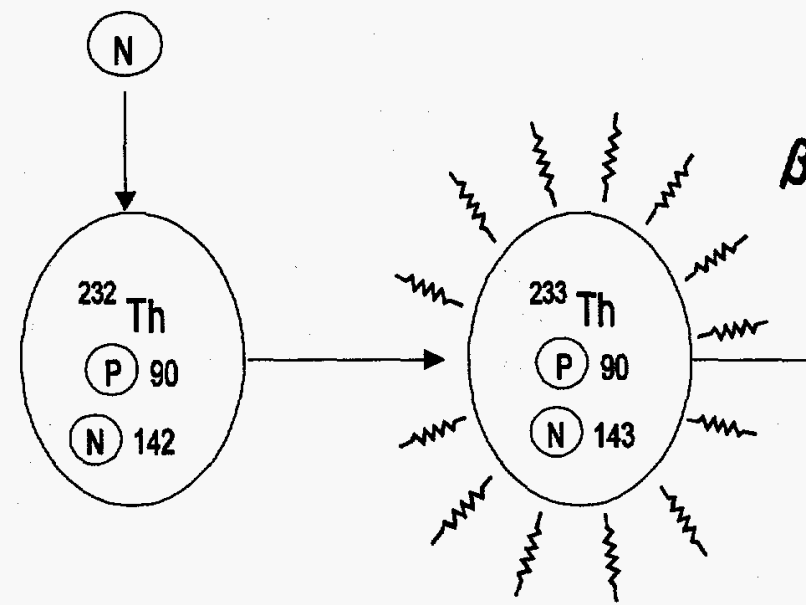

(P) = Proton.

$(\mathbb{N})=$ Neutron

$\beta^{-}=$Beta particle.

Note: Time given is the half-life of the decaying element. ${ }^{233} U$ has a half-life of 163,000 years.

Source: Energy Information Administration, Office of Coal, Nuclear, Electric, and Alternate Fuels.
This process is similar to the formation of plutonium $\left({ }^{239} \mathrm{Pu}\right)$ in the absorption of a neutron by the ${ }^{238} \mathrm{U}$ atom and subsequent decay, as in:

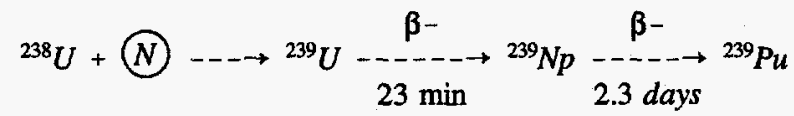

where time given is the half-life of the decaying element. ${ }^{12}$

Natural uranium contains its own source of neutrons in the isotope ${ }^{235} \mathrm{U}$, a naturally fissionable uranium isotope, while thorium, having no neutron-emitting isotope, requires an outside source of neutrons to form ${ }^{233} \mathrm{Th}$. For this reason, thorium is usually used in conjunction with ${ }^{235} \mathrm{U}$ or ${ }^{239} \mathrm{Pu}$. When this nucleus undergoes fission, two or three neutrons are emitted, and the chain reaction is maintained if only one of the neutrons strikes another fissionable nucleus. The other neutrons are generally lost by leakage or by parasitic capture. Thus, when ${ }^{233} \mathrm{U}$ undergoes fission and produces more neutrons than are required for maintaining a chain reaction, the excess neutrons can be used for producing ${ }^{233} \mathrm{U}$ from ${ }^{232} \mathrm{Th}$. This breeding makes the use of thorium in the atomic field especially attractive.

\section{Thorium Fueled Reactor}

The helium gas-cooled HTGR uses pyrocarbon-coated uranium and thorium carbide particles contained in graphite blocks. The graphite also serves as a moderator. ${ }^{13}$ The heat generated in the fuel block is removed by helium gas which transfers the heat from a steam generator to a turbine to produce electricity. In the HTGR, which is designed to burn uranium/thorium fuel, the fully enriched uranium functions as fissile fuel in the initial reactor core and as makeup in a reload segment.

The HTGR fuel is unique because it is an all ceramic fuel and does not contain any metal, making it possible to obtain much higher temperatures than with metal clad fuel elements used in other reactors. This ability to obtain high fuel temperatures leads to high thermal efficiency in the overall system. Furthermore, ${ }^{223} \mathrm{U}$ which is produced when ${ }^{232} \mathrm{Th}$ is used instead of, or in addition to ${ }^{238} \mathrm{U}$, as "fertile material" ${ }^{14}$ in nuclear reactors, has a relatively high "cross section" (the likelihood of an atom's being hit by a neutron) for thermal neutrons. Thus, in theory, it is even more effective than ${ }^{235} \mathrm{U}$ in "accepting" a thermal neutron, to fission and release energy immediately.

\footnotetext{
${ }^{12}$ National Lead Company of Ohio, The Thorium Production Technology, prepared under contract with U.S. Atomic Energy Commission (1958), p. 7

${ }^{13}$ A material, such as ordinary water, heavy water, or graphite used in a reactor to slow down high-velocity neutrons, thus controlling the fission in the reactor core.

${ }^{14}$ Material that is not fissionable by itself but can be converted to fissile material under irradiation.
} 


\section{Problem Areas}

There are, however, many problems with thorium applications in nuclear energy. First of all, thorium does not exactly compete with uranium; it may supplement ${ }^{238} \mathrm{U}$ as a "fertile material," but cannot replace it completely. It must be used in conjunction with one of the fissionable materials $-{ }^{235} \mathrm{U}$, or ${ }^{239} \mathrm{Pu}$. The use of excessive fully enriched ${ }^{235} \mathrm{U}$ as the fissile fuel to activate ${ }^{232} \mathrm{Th}$ until it reaches equilibrium to sustain ${ }^{232} \mathrm{Th} /{ }^{233} \mathrm{U}$ cycle, is not economic. Further, the use of recycled fissile ${ }^{239} \mathrm{Pu}$ is not practical in the United States mainly due to both proliferation and economic concerns as well as lack of reprocessing infrastructure. Breeder reactors are generally characterized by high capital costs.

There are also unresolved fundamental problems as real life is seldom as simple as the theoretical formula. The usual course of events that occurs when a neutron is absorbed by ${ }^{232} \mathrm{Th}$ is shown in Figure 2. But occasionally the unstable ${ }^{233} \mathrm{Th}$ starts its decay process by giving off a couple of neutrons instead of a beta particle, like:

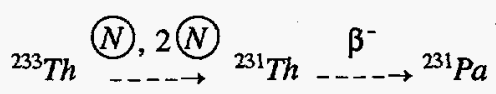

The symbols above the arrows mean that first one neutron $(\mathrm{N})$ was absorbed by the thorium and then two neutrons ( $2 \mathrm{~N}$ ) were emitted. Without any further bombardment, the thorium next lost a beta particle $(\beta)$ and turned into an isotope of protactinium $\left({ }^{231} \mathrm{~Pa}\right)$ with an atomic weight of 231 . This represents the beginning of several possible nuclear reactions which would eventually produce ${ }^{232} \mathrm{U}$ instead of ${ }^{233} \mathrm{U}$. The ${ }^{232} \mathrm{U}$ causes no particular trouble immediately, but its subsequent radioactive decay produces gamma $(\gamma)$ activities from ${ }^{232} \mathrm{U}$ daughters, particularly the tallium isotope $\left({ }^{208} \mathrm{Tl}\right)$, complicating fuel refabrication and recycling of thorium. ${ }^{15}$

The ${ }^{232} U$ concentration builds up gradually throughout the fuel exposure lifetime. Therefore, the thorium spent fuel would require handling methods and safeguards similar to those used for plutonium and would not provide any significant environmental or safety advantage over the use of the uranium/plutonium fuel cycle already demonstrated for decades with thermal and fast neutron reactors.

\section{Research Efforts}

To rejuvenate interest in the thorium-fueled power reactor, there must be either a drastic uranium resource shortage or a significant research and development effort on the thorium fuel cycle. If the latter should occur, the main thrust of the research program would be directed to: (1) the examination of various fuel cycles for the optimal way to introduce thorium into the current generation of reactors without upsetting the ongoing power program; (2) an economic fabrication technique for the thorium base $\left(\mathrm{ThO}_{2} / \mathrm{PuO}_{2}\right)$ mixed oxide fuel (MOX) similar to the fabrication of the uranium base MOX $\left(\mathrm{UO}_{2} / \mathrm{PuO}_{2}\right)$, which is currently being used in the LWR by some utilities in Europe (Belgium, France, Germany, and Switzerland) and Japan.

Present technology allows plutonium from spent fuel to mix with natural uranium, enrichment tails, or depleted uranium to form a mixed oxide fuel through reprocessing, an oxide fuel that is then recycled back into an LWR. The recent trend of interest in LWR MOX is increasing in Europe and Japan mainly because of its uranium enrichment savings as well as its being a partial solution to the actinide containing waste disposal. Unlike the Americans, the Europeans and the Japanese also have been actively pursuing reprocessing and recycling of fuel products in connection with FBR and LMFBR, such as SuperPhoenix (France) and SNR-300 (Germany) programs. Japan and India continue to be active in research on the development of thorium-fueled breeder reactors.

Thorium can be used in almost any sort of reactor in forms of metal slugs, molten salt, oxide compounds, or carbide compounds. Another type reactor suitable for thorium fuel cycle, other than the HTGR and the LWBR, would be the rather exotic Molten-Salt Breeder Reactor (MSBR). The MSBR is an advanced breeder concept which is suited for utilizing thorium for nuclear power generation. Unlike conventional reactors, the MSBR has no external coolant in the reactor core and the fuel salt itself is circulated through a heat exchanger, which transfers the heat produced from fission to a secondary salt for steam generation. This on-line processing scheme makes the MSBR achieve the highest breeding ratio among all thermal breeder reactors.

Recently in the world nuclear community, a new philosophy based on the following three principles has been proposed: (1) thorium utilization, (2) molten-salt fuel concept, and (3) separation of fissile-breeder and power-generating function. Such a philosophy is known as "Thorium Molten-Salt Nuclear Energy Synergetic" (THRIMS-NES) and is observed in the typical 155 MWe Small Molten-Salt Power Station (FUJI-II) in Japan. ${ }^{16}$ According to the proposal, the THRIMS-NES can effectively provide the essential improvement in issues of resources, safety, power-size flexibility, anti-nuclear

\footnotetext{
${ }^{15}$ Oak Ridge National Laboratory, Intra-Laboratory Correspondence, Effect of Thorium Source on Activity Levels of ${ }^{233} \mathrm{U}$ and Recycle Thorium, (May 9, 1977).

${ }^{16}$ India Nuclear Society, Proceedings of the Indo-Japan Seminar on Thorium Utilization (Bombay, India, 1991) p. 21-28.
} 
proliferation, and economy while also securing the simple operation, maintenance, and rational breeding fuel cycle. If its commercialization should become successful, the improved thorium cycle would provide energy to the Third World nations (e.g., Brazil and India) that would be cleaner, concentrated, and reduce proliferation risk.

\section{Environmental Restoration of Thorium Facilities}

\section{Regulations}

Thorium $\left({ }^{232} \mathrm{Th}\right.$ ), like uranium $\left({ }^{238} \mathrm{U}\right)$, was classified as a "source material" by the Atomic Energy Commission (AEC) pursuant to the provisions of Section 61 of the Atomic Energy Act of 1954 (P.L. 83-703, as amended). Section 11e(2) of the Act defines "byproduct material" as tailings or waste produced by extraction of uranium or thorium from any ore processed primarily for its "source material" content. Consequently, the regulatory responsibility for thorium site remediation remains with the Nuclear Regulatory Commission (NRC) or the appropriate "agreement states"17 and subject to Domestic Licensing of Source Material (10 CFR Part 40).

The Uranium Mill Tailings Radiation Control Act (UMTRCA) of 1978 (P.L. 95-604) is the basis for present-day control of both uranium and thorium sites. ${ }^{18}$ In addition to the UMTRCA requirement, the licensee must comply with other supplemental standards, such as Health and Environmental Protection Standards for Uranium and Thorium Mill Tailings, Environmental Protection Agency, 1994 (40 CFR Part 192). The environmental management of both uranium and thorium sites share common objectives of reducing gamma radiation to the background level and limiting the radon $\left({ }^{222} \mathrm{Rn}\right)$ emanation to about twice the rate of surrounding environs.

Recently, Title X of the Energy Policy Act of 1992 (Public Law 102-486) established a new responsibility for the DOE, requiring it to reimburse licensees of active uranium or thorium processing sites for remedial action costs attributable to byproduct material (mill tailings) generated as an incidence of uranium or thorium sales to the United States. For thorium, Kerr-McGee Chemical Corporation's (KMCC) West Chicago, Illinois, thorium processing facility is the sole thorium site eligible for the remedial cost reimbursement of up to $\$ 65$ million, under the current Public Law 104-259.

Most of the other earlier production sites which supplied thorium to the Manhattan Project have been restored under the DOE's "Formerly Utilized Sites Remedial Action Program" (FUSRAP). Some sites which produced thorium as a byproduct and not as the primary "source material" would not fall under either Title $X$ or UMTRCA program.

\section{Government Procurement}

The earliest documents available concerning the Government contracts to purchase thorium nitrate processed at the West Chicago facility date from late 1945 . These documents ${ }^{19}$ refer to thorium nitrate under the secret code name "Penbarnite." From 1946 to 1963, Lindsay Light and Chemical Company (LLCC) and its successor, American Potash \& Chemical Corporation, sold approximately 11.7 million pounds of thorium nitrate (Table 3 ) to the U.S. Government. The arrangement was made through "barter contracts" between LLCC's agent, Continental Ore Corporation, as suppliers, and the Commodity Credit Corporation, the purchasing agent of the U.S. Department of Agriculture for a Government stockpile. The stockpile was administered by the General Services Administration for use by the AEC. All aspects of the barter contracts, including the production, exchange, storage, handling, and sales of thorium nitrate, were under the auspices and control of the AEC. ${ }^{20}$

Aside from KMCC's West Chicago site, ${ }^{21}$ there were four other domestic companies (Heavy Minerals, Inc.; W.R. Grace and Company; Wolfe Alpot; and Lanette Bleachery) which had sold a combined total of 194 short tons thorium oxide equivalent to the Government during $1940 \mathrm{~s}$ and $1950 \mathrm{~s} .{ }^{22}$ In addition, the Government acquired a total of 854 short tons (including 26 short tons captured during World War II) of thorium oxide equivalent through imports from Brazil, France, and India prior to 1960.

\section{Site Remediation}

The West Chicago facility extracted thorium and other compounds from monazite ore beginning in 1934 for use in the production of mantles for gas lamps. Kerr-McGee acquired

\footnotetext{
${ }_{17}$ A State that is or has been a party to a discontinuance agreement with NRC under Section 274 of the Atomic Energy Act (42 U.S.C. 2021) and that agrees on issues pursuant to a counterpart in its State laws to Section 62 or 81 of the Atomic Energy Act.

${ }^{18}$ Energy Information Administration, Decommissioning of U.S. Uranium Production Facilities (Washington, DC, February 1995), p. 3-4.

19 Documents for contracts with the Manhattan Engineer District in 1945 and the Atomic Energy Commission in 1946.

${ }^{20}$ Kerr-McGee Corporation, "Report of Kerr-McGee Chemical Corporation on the Federal Reimbursement Ratio Applicable to the West Chicago Facility" (Oklahoma City, Oklahoma, December 1993), p. 5.

${ }^{21}$ Kerr-McGee's West Chicago site is the largest thorium supplier (5,850 short tons of thorium nitrate) to the Government.

${ }^{22}$ U.S. Department of Energy, Grand Junction Project Office, Various fragmentary documents compiled in the early 1970 s.
} 
Table 3. U.S. Government Procurement of Thorium Nitrate from the West Chicago Facility, 1946-1963 (Pounds Th $\left(\mathrm{NO}_{3}\right)_{4} 4 \mathrm{H}_{2} \mathrm{O}$ )

\begin{tabular}{|c|c|c|}
\hline $1946 \ldots \ldots \ldots \ldots \ldots$ & W-17-028-ENG-33 & 9,000 \\
\hline 1946-1953 . & W-17-028-ENG-35 & $1,603,248$ \\
\hline $1953-1956$ & AT(30-1)-1392 & $3,000,000$ \\
\hline 1957 & AT(40-1)-S-1182 & $1,000,000$ \\
\hline $1957-1960 \ldots$ & BSD-AE-57-47 & $4,085,957$ \\
\hline Total $\ldots \ldots \ldots \ldots \ldots \ldots \ldots \ldots \ldots \ldots \ldots \ldots$ & & $11,737,605$ \\
\hline
\end{tabular}

Source: Kerr-McGee Chemical Corporation, Report of the Kerr-McGee Chemical Corporation on the Federal Reimbursement Ratio Applicable to the West Chicago Facility (Oklahoma City, OK, December 1993), p. 23.

ownership of the facility through a merger with American Potash in 1967. The final Government contract to produce thorium ended in 1963, and KMCC terminated all commercial milling operations from West Chicago facility in 1973.

This facility had generated total mill tailings of 57,900 short tons, of which 32,400 tons were accountable for "Federalrelated" tailings. ${ }^{23}$ Contrasting with the remoteness of most uranium sites in the Western United States, this thorium facility is located in the City of West Chicago, lllinois, and requires an off-site disposal. The mill tailings residues in form of sands and sludge must be relocated to a licensed offsite disposal site. Kerr-McGee is now in the process of removing the mill tailings and associated waste material to a NRC licensed disposal site owned by Envirocare of Utah, Inc. near Clive, Utah, in compliance with rules governed by the Illinois (an "agreement state") Department of Nuclear Safety in concert with the U.S. NRC. Current and anticipated future costs in the remediation of this facility are substantial due to the need for tailings relocation. Kerr-McGee estimates the total costs to complete the closure of the West Chicago thorium facility at approximately $\$ 178$ million. ${ }^{24}$

The Fort St. Vrain HTGR, which has been permanently shut down since 1989, is now decommissioned. The graphite fuel segments from the HTGR are currently stored in PSC's Independent Spent Fuel Storage Installation (ISFSI) sites which uses a dry storage system. The spent fuel will be shipped to DOE's Idaho National Engineering Laboratory only if the fuel requires special treatment before it can be placed in interim storage or a permanent repository. Following years of reconstruction for conversion efforts, the "new" Fort St. Vrain plant began operation as a natural gas-fired power plant on April 30, 1996. ${ }^{25}$

Thorium waste generated by various Government laboratories has been stored at the Department of Energy's Fernald operations site in Ohio since the 1970s. Under the Fernald Environmental Management Project, almost 6,000 gallons of thorium nitrate (a contaminated acid waste) have been treated and solidified safely in 55-gallon drums for safe shipment to an off-site disposal facility. In all, 369 drums of solidified thorium cement were generated. ${ }^{26}$

\section{Conclusion}

Although it is known that thermal nuclear reactors can convert ${ }^{232} \mathrm{Th}$ to the fissile ${ }^{233} \mathrm{U}$ more efficiently and with a higher conversion rate than they can convert ${ }^{238} \mathrm{U}$ to fissile ${ }^{239} \mathrm{Pu}$, the commercial application with good neutron economy that could attain self-sufficiency on thorium alone has not yet been developed. In addition, there is presently available an abundant supply of low-price uranium.

There is also a surplus inventory of highly enriched uranium (HEU) in various forms of uranium equivalent from the post cold war weapons disarmament program which is directly marketable or can be blended-down and reprocessed for use in commercial reactors. Therefore, under these circumstances,

\footnotetext{
${ }^{23}$ Science Applications International Corporation, "Title X Mill Tailings Quantity Evaluation," Prepared for the Energy Information Administration (McLean, Virginia, February 1994), p. 7.

${ }^{24}$ Kerr-McGee Corporation, "Report of Kerr-McGee Chemical Corporation on the Federal Reimbursement Ratio Applicable to the West Chicago Facility" (Oklahoma City, Oklahoma, December 1993), p. 5.

${ }^{25}$ California Energy Market, "Public Service Company of Colorado's Converted Nuke Plant Reborn with Natural Gas" (www.newspage.com, May 8, 1996).

${ }^{26}$ U.S. Department of Energy, DOE This Month (Washington, DC, January 1996) p. 15.
} 
the natural tendency is to use uranium, which is cheaply available, already on hand and uses proven technology, even though thorium might theoretically offer equal or greater benefits.

For countries like India and Brazil with vast reserves of thorium and comparatively low known uranium reserves, thorium utilization with self sufficiency, ensuring long-range nuclear fuel options, is of great significance for their future nuclear power program. In the United States, however, converting from the use of uranium to thorium is unlikely for quite some time unless there happens to be a substantial shortage of cheap uranium or a significant breakthrough in the thorium fuel cycle technology that is commercially viable to justify the economic and/or environmental advantages of using thorium rather than uranium. 



\section{Highlights}

The U.S. uranium industry continued in 1996 its turnaround that began in 1995. Domestic uranium mine and concentrate production were at their highest levels in five years, and the employment in the mining sector of the industry increased by 47 percent compared with 1995 . The following are highlights of the year.

\section{Uranium Raw Material Activities}

Uranium production (in the form of uranium concentrate) in 1996 totaled 6.3 million pounds $\mathrm{U}_{3} \mathrm{O}_{8}$, an increase of 5 percent from the 1995 level, and the highest level since 1991 (Table H1). Seven uranium concentrate production facilities were commercially operating at the end of 1996 : five in situ leach plants and two byproduct recovery plants. Conventional mills accounted for 14 percent of the total production, and nonconventional plants accounted for 86 percent. One conventional mill processed uranium concentrate from stockpiled ores. Uranium concentrate shipments from U.S. producers were 6.0 million pounds in 1996, an increase of 9 percent compared with the 1995 shipments.

During 1996, a total of 4.7 million pounds $\mathrm{U}_{3} \mathrm{O}_{8}$ of uranium were produced by U.S. mines, the highest level of production since 1991. Most of that amount was by in situ leach methods. Compared with 1995, 1996 production represents an increase of 33 percent. For the first year since 1992, ore was mined from an underground mine. However, it was the fourth consecutive year in which no ore was mined from openpit mines.

Total exploration and development expenditures in 1996 were $\$ 10.1$ million, a 67 -percent increase from 1995 , due to a significant increase in development drilling activities. Foreign participation in U.S. uranium exploration and development activities was $\$ 4.4$ million, more than a twofold increase compared with 1995, and represented 44 percent of the total expenditures.

Employment in the raw materials sector of the uranium industry increased during 1996 by 1 percent to 1,118 person years. This is the fourth consecutive year of increasing employment.

\section{Uranium Marketing Activities}

\section{Purchases}

Domestic and foreign suppliers delivered a total of 47.3 million pounds $\mathrm{U}_{3} \mathrm{O}_{8} \mathrm{e}$ (equivalent) to U.S. utilities in 1996 (Table H2). Utilities were delivered 9 percent more uranium, compared with the 1995 level. The average price paid by the utilities was $\$ 14.12$ per pound $\mathrm{U}_{3} \mathrm{O}_{8} \mathrm{e}$, an increase of 26 percent compared with the 1995 price.

U.S. brokers and traders purchased a total of 25.3 million pounds $\mathrm{U}_{3} \mathrm{O}_{8} \mathrm{e}$ in 1996 . The average price for these purchases was $\$ 12.61$ per pound, an increase of 32 percent compared with the 1995 price.

\section{Imports and Exports}

In 1996, purchases from foreign suppliers by U.S. suppliers and utilities totaled 45.4 million pounds $\mathrm{U}_{3} \mathrm{O}_{8} \mathrm{e}$, at an average price of $\$ 13.15$ per pound (Table $\mathrm{H} 2$ ). This represents an increase of 29 percent compared with the 1995 price.

Uranium export sales to foreign suppliers and utilities was 11.5 million pounds, at an average price of $\$ 14.20$ per pound. Compared with 1995 , the price was 5 percent higher.

\section{Uranium in Fuel Assemblies}

Utilities loaded fuel assemblies that contained 45.5 million pounds $\mathrm{U}_{3} \mathrm{O}_{8} \mathrm{e}$ into U.S. commercial nuclear reactors during 1996, 5.7 million pounds less than in 1995 (Table H3).

\section{Inventories}

Uranium inventories held by U.S. utilities rose in 1996 reaching 67.5 million pounds $\mathrm{U}_{3} \mathrm{O}_{8} \mathrm{e}$ at the end of the year (Table H3). This represented a 15 percent increase from the level of inventories at the end of 1995, but was 58 percent below the record-high level of inventories held by utilities at the end of 1984 (160.2 million pounds). 
Table H1. Raw Materials Summary Statistics of the U.S. Uranium Industry, 1987-1996

\begin{tabular}{|c|c|c|c|c|c|c|c|c|c|c|}
\hline Items & 1987 & 1988 & 1989 & 1990 & 1991 & 1992 & 1993 & 1994 & 1995 & 1996 \\
\hline \multicolumn{11}{|l|}{ Exploration and Development } \\
\hline Surface Drilling (million feet) ...... & 2.0 & 3.0 & 2.2 & 1.7 & 1.8 & 1.1 & 1.1 & 0.7 & 1.3 & 3.0 \\
\hline (million meters) & 0.6 & 0.9 & 0.7 & 0.5 & 0.6 & 0.3 & 0.3 & 0.2 & 0.4 & 0.9 \\
\hline Expenditures $^{a}$ (million dollars). & 19.7 & 20.1 & 14.8 & 17.1 & 17.8 & 14.5 & 11.3 & 3.7 & 6.0 & 10.1 \\
\hline \multicolumn{11}{|l|}{$\begin{array}{l}\text { Reserves at End of Year } \\
\text { (million pounds } \mathrm{U}_{3} \mathrm{O}_{8}\end{array}$} \\
\hline $\begin{array}{l}\text { \$US30 per pound) ........... } \\
\text { (thousand metric tons } U \text {, }\end{array}$ & 304 & 289 & 277 & 265 & 304 & 295 & 292 & 294 & 290 & 285 \\
\hline$\$$ US80 per kilogram) ................. & 117 & 111 & 107 & 102 & 117 & 114 & 112 & 113 & 112 & 110 \\
\hline \multicolumn{11}{|l|}{ Mine Production of Uranium } \\
\hline 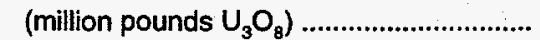 & 6.0 & 9.5 & 9.7 & 5.9 & 5.2 & 1.0 & 2.1 & 2.5 & 3.5 & 4.7 \\
\hline 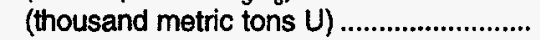 & 2.3 & 3.7 & 3.7 & 2.3 & 2.0 & 0.4 & 0.8 & 1.0 & 1.4 & 1.8 \\
\hline \multicolumn{11}{|l|}{ Uranium Concentrate Production } \\
\hline (million pounds $\mathrm{U}_{3} \mathrm{O}_{8}$ ) & 13.0 & 13.1 & 13.8 & 8.9 & 8.0 & 5.6 & 3.1 & 3.4 & 6.0 & 6.3 \\
\hline 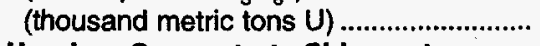 & 5.0 & 5.1 & 5.3 & 3.4 & 3.1 & 2.2 & 1.2 & 1.3 & 2.3 & 2.4 \\
\hline \multicolumn{11}{|l|}{ Uranium Concentrate Shipments } \\
\hline 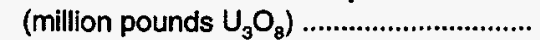 & 11.6 & 12.8 & 14.8 & 13.0 & 8.4 & 6.9 & 3.4 & 6.3 & 5.5 & 6.0 \\
\hline 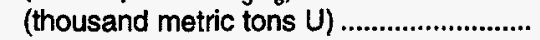 & 4.4 & 4.9 & 5.7 & 5.0 & 3.2 & 2.6 & 1.3 & 2.4 & 2.1 & 2.3 \\
\hline Employment (person-years expended) ... & 2,002 & 2,141 & 1,583 & 1,335 & 1,016 & 682 & 871 & 980 & 1,107 & 1,118 \\
\hline
\end{tabular}

Expenditures are in nominal U.S. dollars.

Note: Specitic references for each category of data and year are provided in various detailed text or tables included in the main body of this report. For 1993 through 1996, total employment includes reclamation employment.

Sources: Energy Information Administration: 1987-1995-Uranium Industry Annnual 1995 (May 1996); 1996-Form EIA-858, "Uranium Industry Annual Survey" (1996).

Table H2. Transaction Summary Statistics of the U.S. Uranium Industry, 1994-1996

\begin{tabular}{|c|c|c|c|c|c|c|}
\hline \multirow[b]{2}{*}{ Actual Deliveries } & \multicolumn{2}{|r|}{1994} & \multicolumn{2}{|r|}{1995} & \multicolumn{2}{|r|}{1996} \\
\hline & Quantity & $\begin{array}{c}\text { Weighted- } \\
\text { Average Price }\end{array}$ & Quantity & $\begin{array}{c}\text { Weighted- } \\
\text { Average Price }\end{array}$ & Quantity & $\begin{array}{c}\text { Weighted- } \\
\text { Average Price }\end{array}$ \\
\hline $\begin{array}{l}\text { Purchases by U.S. Brokers and Traders } \\
\text { (million pounds } \mathrm{U}_{3} \mathrm{O}_{8} \mathrm{e} \text {; dollars per pound } \mathrm{U}_{3} \mathrm{O}_{8} \theta \text { ) ..... } \\
\text { (thousand metric tons U; dollars per kilogram U) ..... } \\
\text { Purchases by U.S. Utilities }\end{array}$ & $\begin{array}{l}30.8 \\
11.8\end{array}$ & $\begin{array}{r}8.29 \\
21.56\end{array}$ & $\begin{array}{r}22.9 \\
8.8\end{array}$ & $\begin{array}{r}9.53 \\
24.79\end{array}$ & $\begin{array}{r}25.3 \\
9.7\end{array}$ & $\begin{array}{l}12.61 \\
32.79\end{array}$ \\
\hline $\begin{array}{l}\text { (million pounds } \mathrm{U}_{3} \mathrm{O}_{8} \mathrm{e} \text {; dollars per pound } \mathrm{U}_{3} \mathrm{O}_{8} \mathrm{e} \text { ) ..... } \\
\text { (thousand metric tons } \mathrm{U} \text {; dollars per kilogram } \mathrm{U} \text { ) .... } \\
\text { Imports by U.S. Suppliers and Utilities }\end{array}$ & $\begin{array}{l}38.3 \\
14.7\end{array}$ & $\begin{array}{l}10.40 \\
27.03\end{array}$ & $\begin{array}{l}43.4 \\
16.7\end{array}$ & $\begin{array}{l}11.25 \\
29.24\end{array}$ & $\begin{array}{l}47.3 \\
18.2\end{array}$ & $\begin{array}{l}14.12 \\
36.71\end{array}$ \\
\hline $\begin{array}{l}\text { (million pounds } \mathrm{U}_{3} \mathrm{O}_{8} \mathrm{e} \text {; dollars per pound } \mathrm{U}_{3} \mathrm{O}_{8} \mathrm{e} \text { )..... } \\
\text { (thousand metric tons } \mathrm{U} \text {; dollars per kilogram } \mathrm{U} \text { ) .... }\end{array}$ & $\begin{array}{l}36.6 \\
14.1\end{array}$ & $\begin{array}{r}8.95 \\
23.27\end{array}$ & $\begin{array}{l}41.3 \\
15.9\end{array}$ & $\begin{array}{l}10.20 \\
26.52\end{array}$ & $\begin{array}{l}45.4 \\
17.5\end{array}$ & $\begin{array}{l}13.15 \\
34.19\end{array}$ \\
\hline $\begin{array}{l}\text { Exports by U.S. Suppliers and Utilities } \\
\text { (million pounds } \mathrm{U}_{3} \mathrm{O}_{8} \mathrm{e} \text {; dollars per pound } \mathrm{U}_{3} \mathrm{O}_{8} \mathrm{e} \text { )..... } \\
\text { (thousand metric tons } \mathrm{U} \text {; dollars per kilogram } \mathrm{U} \text { ).... }\end{array}$ & $\begin{array}{r}17.7 \\
6.8\end{array}$ & $\begin{array}{l}11.34 \\
29.49\end{array}$ & $\begin{array}{l}9.8 \\
3.8\end{array}$ & $\begin{array}{l}13.48 \\
35.06\end{array}$ & $\begin{array}{r}11.5 \\
4.4\end{array}$ & $\begin{array}{l}14.20 \\
36.92\end{array}$ \\
\hline
\end{tabular}

$\mathrm{U}_{3} \mathrm{O}_{8} \mathrm{e}=\mathrm{U}_{3} \mathrm{O}_{8}$ equivalent.

Source: Energy Information Administration, Form EIA-858, "Uranium Industry Annual Survey" (1994-1996).

Table H3. Summary Statistics of Uranium Fuel and Commercial Inventories, 1994-1996

\begin{tabular}{|c|c|c|c|}
\hline Items & 1994 & 1995 & $1996^{P}$ \\
\hline 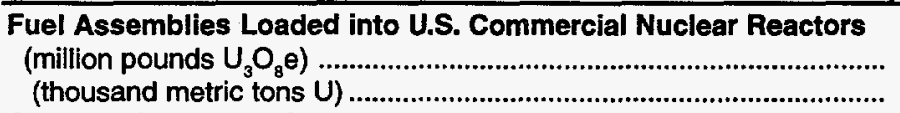 & $\begin{array}{l}40.4 \\
15.5\end{array}$ & $\begin{array}{l}51.1 \\
19.7\end{array}$ & $\begin{array}{l}45.5 \\
17.5\end{array}$ \\
\hline 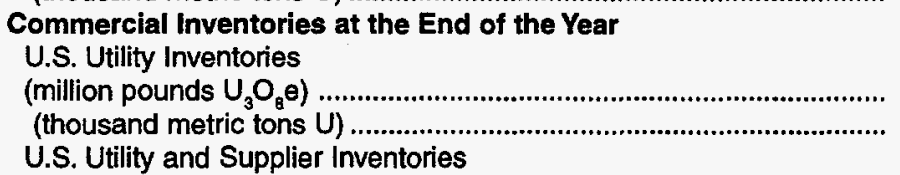 & $\begin{array}{l}65.4 \\
25.2\end{array}$ & $\begin{array}{l}\text { R58.7 } \\
\text { R22.6 }\end{array}$ & $\begin{array}{l}67.5 \\
26.0\end{array}$ \\
\hline $\begin{array}{l}\left.\text { (million pounds } \mathrm{U}_{3} \mathrm{O}_{8} \mathrm{e}\right) \\
\text { (thousand metric tons } \mathrm{U} \text { ) }\end{array}$ & $\begin{array}{l}86.9 \\
33.4\end{array}$ & $\begin{array}{l}R 72.5 \\
R 27.9\end{array}$ & $\begin{array}{l}81.2 \\
31.2\end{array}$ \\
\hline
\end{tabular}

$\mathrm{U}_{3} \mathrm{O}_{8} \mathrm{e}=\mathrm{U}_{3} \mathrm{O}_{8}$ equivalent.

$P=$ Preliminary data. $R=$ Revised data. Final 1995 data reported in the 1996 survey.

Source: Energy Information Administration, Form ElA-858, "Uranium Industry Annual Survey" (1995-1996). 


\section{U.S. Uranium Raw Materials Industry}

\section{Introduction}

The levels of activity in the U.S. uranium raw materials industry were higher at the end of 1996, compared with 1995. Expenditures for exploration, drilling, and related activities reported for 1996 were more than in 1995 (Figure 1). Mine production of uranium increased (Figure 2) and a first underground mine in four years restarted its operation in 1996. Uranium concentrate production also increased in 1996 (Figure 3). Total employment for uranium exploration, mining, milling, and processing increased in 1996 compared with 1995 (Figure 4), with mining claiming a 47 percent increase. Employment for reclamation activities declined for the first time since 1993.

Uranium concentrate was produced in 1996 from conventional milling, in situ leach methods, and as a byproduct of wet-process phosphoric acid manufacture. One conventional uranium mill was in commercial operation during the early part of 1996, but it was inactive at the end of 1996. Also, a small amount of uranium was recovered from the processing of mine water and other materials.

\section{Exploration and Development Activities}

\section{Land Holdings and Acquisitions}

U.S. uranium exploration companies held 288 thousand acres for all exploration purposes at the end of 1996 (Table 1). This represents a small increase of land held for exploration at year end, but reverses the trend of declining exploration land held by companies in the United States. About 36,000 acres were acquired for exploration at a total cost of $\$ 403,000$ (Table 2). The types of land acquired and held include fee land, mineral fee leases, patented and unpatented mining claims, and options to purchase mineral fee land.

\section{Surface Drilling}

Surface drilling (exploration and development) in the United States was 3.0 million feet in 4,695 holes (Table 1). Development drilling costs in 1996 was 5.5 million dollars, a 208 percent increase compared with 1995, while exploration drilling costs increased 103 percent (Figure 5).

\section{Expenditures for Uranium Exploration and Development}

Total U.S. uranium exploration and development expenditures in 1996 were $\$ 10.1$ million, consisting of (in millions) $\$ 0.4$ for land, $\$ 7.2$ for surface drilling, and $\$ 2.5$ for other exploration activities (Table 2) This represents a 67 percent increase over the 1995 level, but less than the 1993 level. Participation from foreign sources to U.S. exploration expenditures in 1996 were $\$ 4.4$ million, which represents 44 percent of the total U.S. expenditures in 1996, more than a two-fold increase compared with 1995 , but about one half of the 1993 level.

\section{Estimates of U.S. Uranium Reserves}

As of the end of 1996, the EIA's estimates of uranium reserves in the $\$ 30$ - and $\$ 50$-per-pound categories were 285 and 939 million pounds, respectively. Underground mining reserves accounted for about one-half of the total reserves in each cost category (Table 3). Three States, New Mexico, Texas and Wyoming, contained about 73 percent of $\$ 30$-per-pound $\mathrm{U}_{3} \mathrm{O}_{8}$ reserves (Appendix B, Table B4). Reserve estimates represent the quantities of uranium (as $\mathrm{U}_{3} \mathrm{O}_{8}$ ) that occur in known deposits such that portions of the mineralized deposits can be recovered at specific costs under current regulations using state-of-theart mining and milling methods.

\section{Mine Production of Uranium}

During 1996, a total of 4.7 million pounds $\mathrm{U}_{3} \mathrm{O}_{8}$ of uranium were produced by U.S. mines, the highest level of production since 1991 (Table 4). Production occurred at an underground mine for the first year since 1992, but openpit mines remain inactive. Uranium was also recovered from waste mine-water and from reclamation activities at closed in situ mine sites. Compared with 1995, in situ leach mine production increased 30 percent in 1996. 
There were seven uranium mines that commercially operated during part or all of 1996, two more than in 1995 (Table 4). Six mines operated at the end of 1996. One mine (Holiday El-Mesquite in Texas) shutdown and two (Schwartzwalder in Colorado and Kingsville Dome in Texas) began production in 1996.

\section{Concentrate Production and Shipments}

U.S. uranium concentrate production in 1996 was $6.3 \mathrm{mil}-$ lion pounds $\mathrm{U}_{3} \mathrm{O}_{8}$, an increase of 5 percent above the 1995 level (Table 5). Concentrate production from conventional mills was 0.9 million pounds. This was the second year that uranium concentrate was produced commercially at conventional mills since 1992, but the processing ended in early part of 1996.

Concentrate production in the "Other Processing" category includes production from in situ leaching and as a byproduct of phosphate processing. Compared with 1995 , this category increased 23 percent and totaled 5.5 million pounds $\mathrm{U}_{3} \mathrm{O}_{8}$ in 1996 (Table 5).

Shipments of uranium concentrate from domestic production facilities (mills, in situ and phosphate byproduct plants) totaled 6.0 million pounds in 1996 (Table 5). The total annual production of 6.3 million pounds exceeded annual shipments for the second straight year, the first time since 1988 (Figure 6), which resulted in a twc-year increase of 0.9 million pounds in concentrate inventories held at production facilities at the end of 1996.

\section{Status of Uranium Processing Facilities}

At the end of 1996, 7 conventional mills were inactive, with a milling capacity of 14,400 tones of ore per day
(Table 6). From September, 1995 to February, 1996, one conventional mill (White Mesa in Utah) was commercially producing uranium concentrate from stockpiled ores mined prior to 1993. An additional, small amount of uranium concentrate was recovered (at other mills) from processing of mine water and materials recovered from water treatment plants.

Seven nonconventional uranium producing plants, consisting of five in situ leach plants and two phosphate byproduct plants, were in commercial operation in the United States at the end of 1996. These plants had a combined rated capacity of 7.1 million pounds $\mathrm{U}_{3} \mathrm{O}_{8}$ per year (Table 7). Eight nonconventional plants were inactive at the end of 1996. Five of the six inactive in situ leach plants had produced a small amount of uranium concentrate in 1996 from reclamation activities. The two inactive byproduct plants in Florida were closed indefinitely, and no restart is planned for 1997.

The locations of active (commercially operating) and inactive U.S. uranium concentrate production facilities, along with the locations of major uranium reserve areas, are shown in Figure 7.

\section{Employment}

Employment in the U.S. uranium raw materials industry in 1996 was reported as 1,118 person years expended (Table 8). Compared with 1995, 1996 employment overall rose by only 1 percent. However, employment levels in individual categories changed significantly: mining rose by 47 percent, milling by 28 percent, and processing by 9 percent, while, reclamation employment declined by 25 percent, and exploration employment remained the same. For the first year, reclamation employment was less than the combined employment in uranium exploration, mining, milling and processing. Three States, Colorado, Texas and Wyoming, accounted for 68 percent of the total employment in 1996 (Table 9). 
Figure 1. Exploration and Development Expenditures, 1987-1996

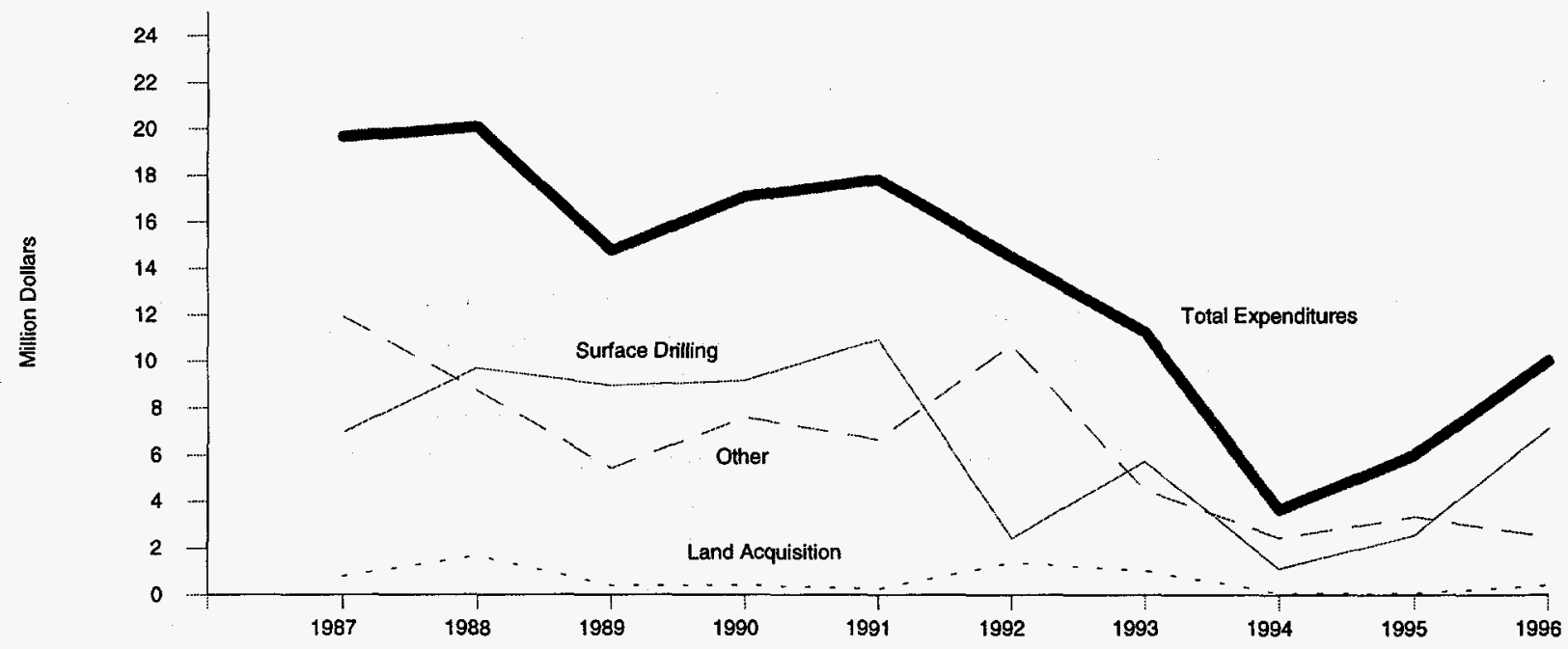

Figure 2. U.S. Uranium Mine Production, 1987-1996

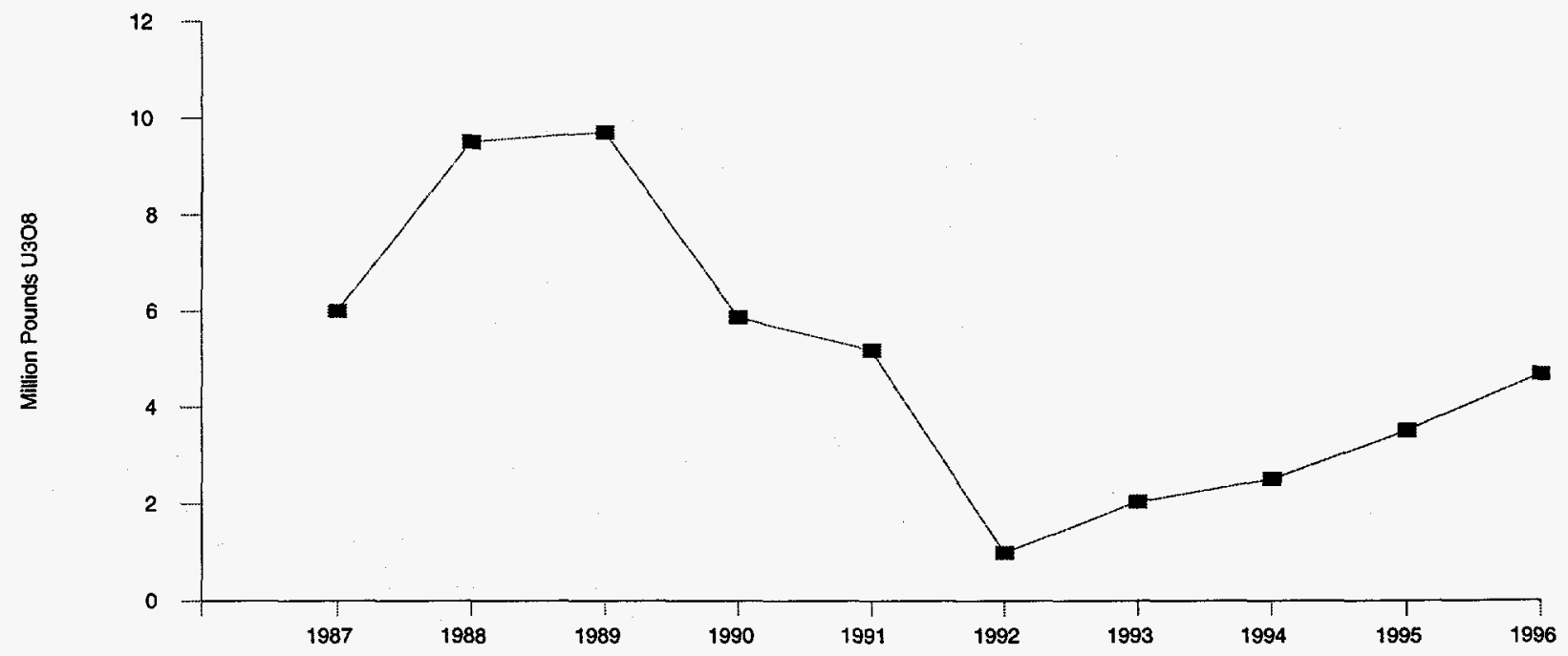

Figure 3. Uranium Concentrate Production, 1987-1996

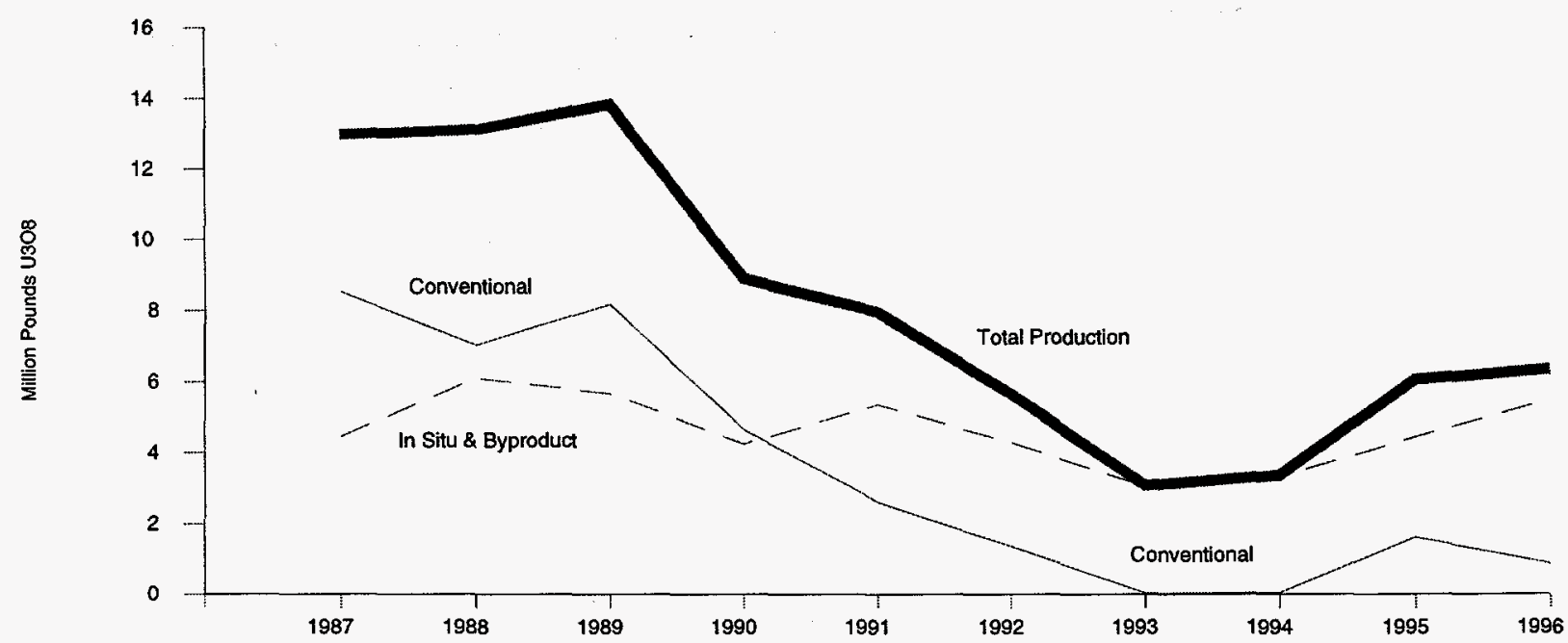

Sources: Energy Information Administration: 1987-1995-Uranium Industry Annual 1995 (May 1996). 1996-Form ElA-858, "Uranium Industry Annua Survey" (1996). 
Figure 4. Employment - Uranium Raw Materials Sector, 1987-1996

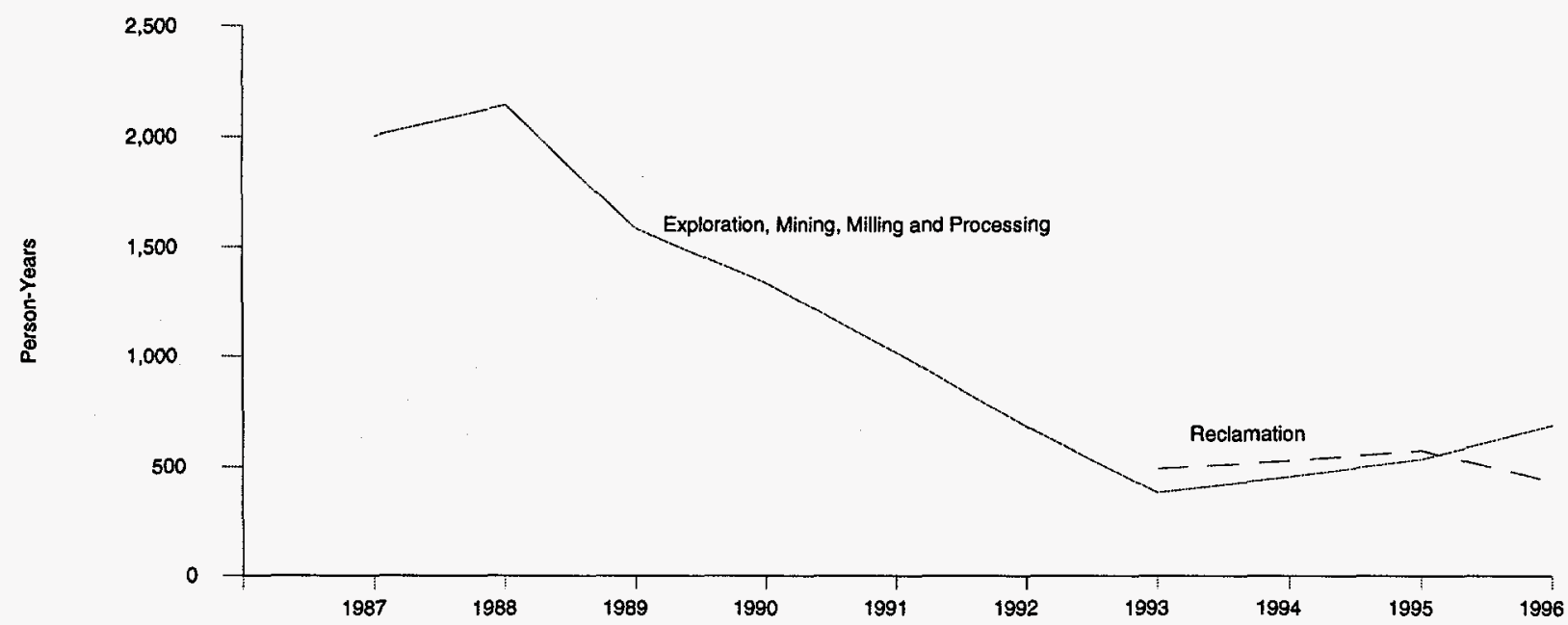

Figure 5. U.S. Uranium Exploration and Development Surface Drilling Cost, 1987-1996

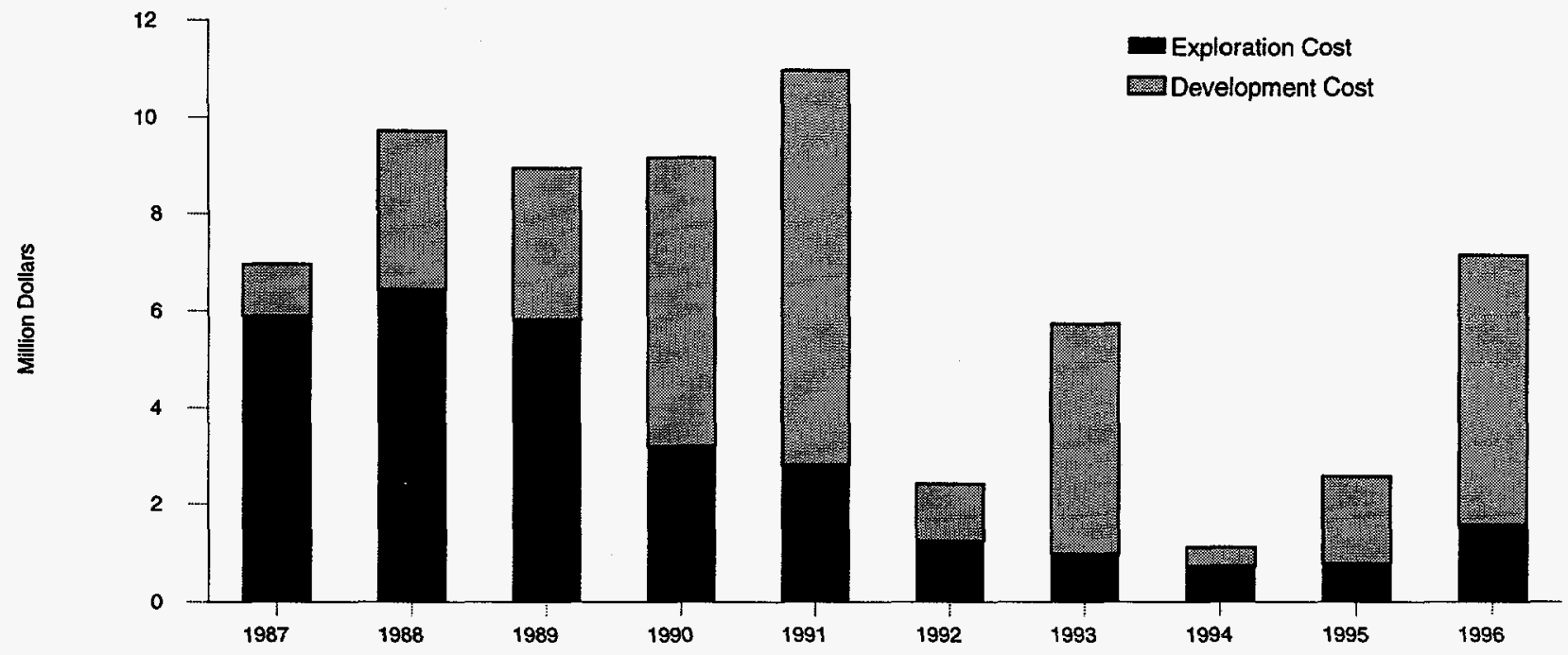

Figure 6. U.S. Uranium Concentrate Production and Shipments, 1987-1996

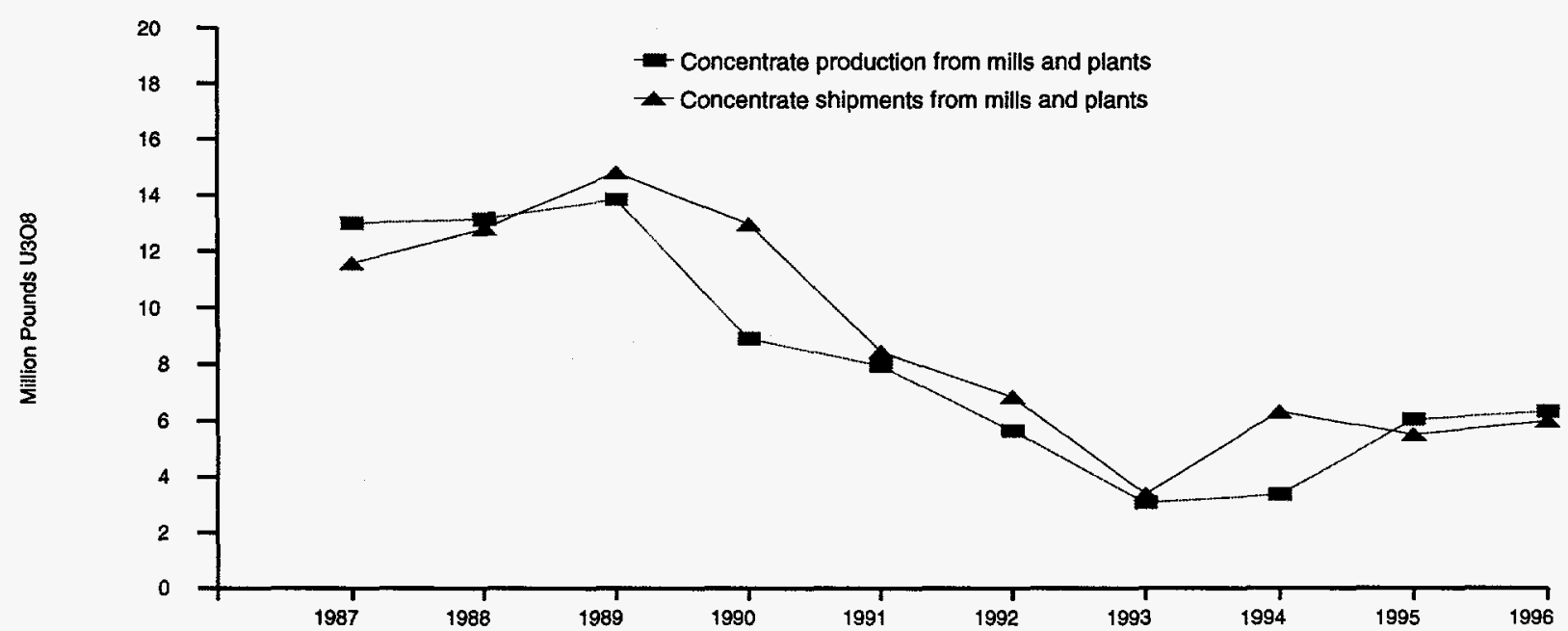

Sources: Energy Information Administration: 1987-1995-Uranium Industry Annual 1995 (May 1996). 1996-Form ElA-858, "Uranium Industry Annual Survey" (1996). 
Figure 7. Major U.S. Uranium Reserve Areas and Status of Mills and Plants, 1996

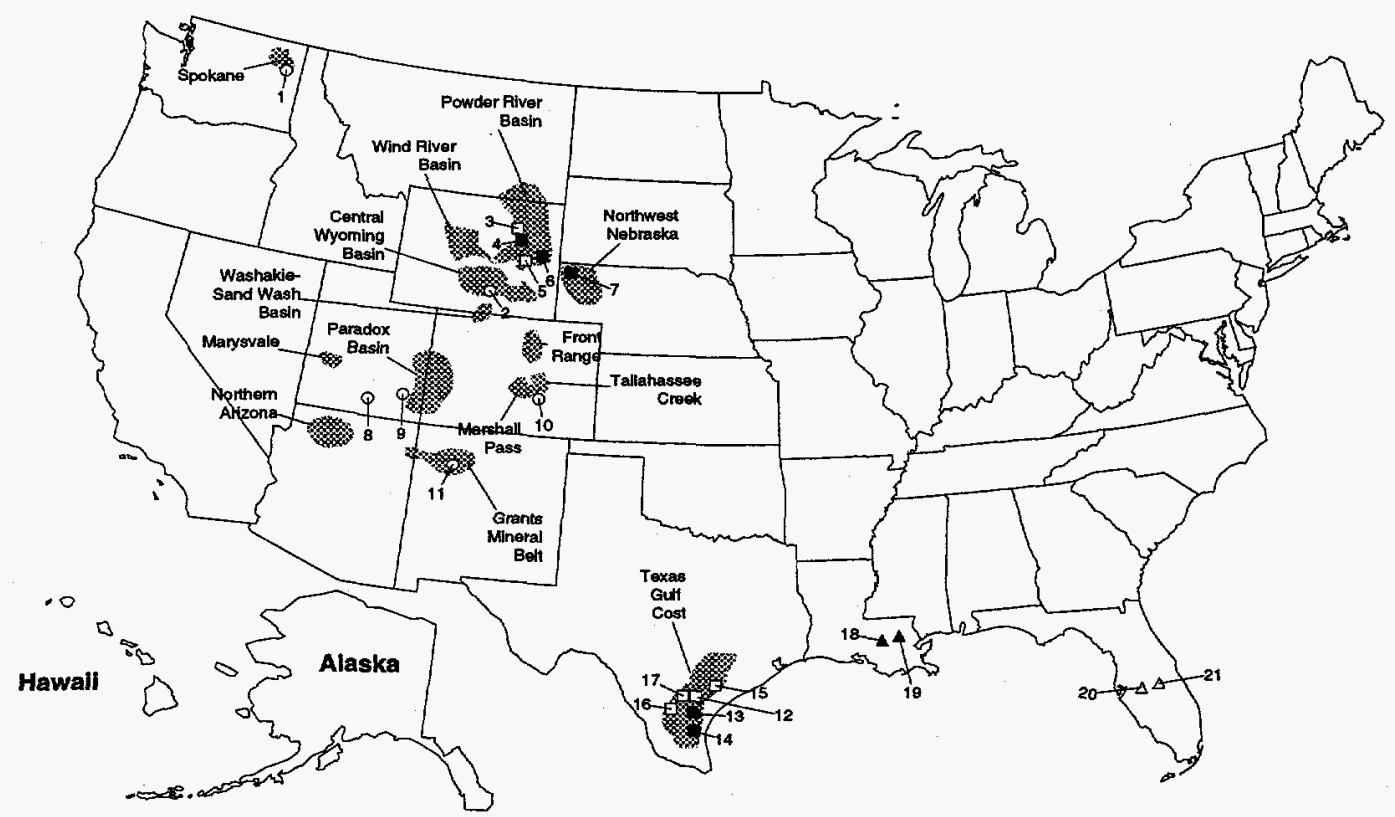

Active at the End of 1996

4. Malapai Resources, Christensen Ranch
6. Converse County Mining Venture, Highland
7. Crow Butte Resources, Crow Butte
13. Uranium Resources, Rosita
14. Uranium Fesources, Kingsville Dome
18. IMC-Agrico, Sunshine Bridge
19. IMC-Agrico, Uncle Sam

\begin{tabular}{|ccl|}
\hline Active & $\begin{array}{c}\text { Uranium Production Centers } \\
\text { Inactive }\end{array}$ \\
$\square$ & 0 & Conventional Mills \\
$\Delta$ & $\square$ & in Situ Leach Plant \\
$\Delta$ & $\triangle$ & Byproduct From Phosphate Processing \\
\hline \multirow{2}{*}{ Major Uranium Reserve Areas ' } \\
\hline
\end{tabular}

Inactive at the End of 1996

\footnotetext{
1. Dawn Mining, Ford a

2. Green Mountain Mining Venture, Sweetwater

3. Malapai Resources, Irigaray b

5. Rio Algom Mining, Smith Ranch b

8. U.S. Energy, Shootaring

9. Energy Fuels Nuclear, White Mesa c. o

10. Cotter Corp., Canon City

11. Rio Algom Mining, Ambrosia d

12. Malapai Resources, Holiday-El Mesquite b,

15. Everest Minerals, Hobson

16. COGEMA Mining, West Cole b

17. Malapai Resources, O'Hem b

20. IMC-Agrico, Plant City

21. IMC-Agrico, New Wales
}

^Recovered uranium by processing water treatment plant sludge byproduct during 1996.

'Recovered uranium by processing water from in situ leach mine restoration during 1996.

'Recovered uranium by processing from ore and other materials during 1996.

'Recovered uranium by processing mine water from conventional mines during 1996.

- Active during part of 1996.

Major areas containing reasonably assured resources at $\$ 50$-per-pound $\mathrm{U}_{3} \mathrm{O}_{8}$ or less.

Sources: Based on U.S. Department of Energy, Grand Junction Project Office (GJPO), National Urainium Resource Evaluation, Interim Report (June 1979) Figure 3.2; GJPO data files; Energy Information Administration, Form EIA-858,"Uranium Industry Annual Survey" (1996); and site visits by staff of the Analysis and Systems Division, Office of Coal, Nuclear, Electric and Alternate Fuel. 
Table 1. U.S. Uranium Land and Surface Drilling Activities, 1987-1996

\begin{tabular}{|c|c|c|c|c|c|c|c|c|c|c|c|}
\hline \multirow[b]{2}{*}{ Year } & \multicolumn{2}{|c|}{$\begin{array}{l}\text { Land } \\
\text { Exploration }\end{array}$} & \multicolumn{3}{|c|}{$\begin{array}{l}\text { Surface Drilling } \\
\text { Exploration }\end{array}$} & \multicolumn{3}{|c|}{$\begin{array}{l}\text { Surface Drilling } \\
\text { Development }\end{array}$} & \multicolumn{3}{|c|}{$\begin{array}{c}\text { Surface Drilling } \\
\text { Exploration and Development }\end{array}$} \\
\hline & $\begin{array}{c}\text { Acres } \\
\text { Acquired } \\
\text { during } \\
\text { Year } \\
\text { (thousand) }\end{array}$ & $\begin{array}{c}\text { Acres } \\
\text { Held } \\
\text { at End of } \\
\text { Year } \\
\text { (thousand) }\end{array}$ & $\begin{array}{c}\text { Number } \\
\text { of } \\
\text { Holes }\end{array}$ & $\begin{array}{c}\text { Feet } \\
\text { (thousand) }\end{array}$ & $\begin{array}{c}\text { Cost } \\
\text { (thousand } \\
\text { dollars) }\end{array}$ & $\begin{array}{c}\text { Number } \\
\text { of } \\
\text { Holes }\end{array}$ & $\begin{array}{c}\text { Feet } \\
\text { (thousand) }\end{array}$ & $\begin{array}{c}\text { Cost } \\
\text { (thousand } \\
\text { dollars) }\end{array}$ & $\begin{array}{c}\text { Number } \\
\text { of } \\
\text { Holes }\end{array}$ & $\begin{array}{c}\text { Feet } \\
\text { (thousand) }\end{array}$ & $\begin{array}{c}\text { Cost } \\
\text { (thousand } \\
\text { dollars) }\end{array}$ \\
\hline $1987 \ldots$ & 90 & 1,900 & 1,820 & 1,110 & 5,900 & 1,994 & 860 & 1,060 & 3,814 & 1,970 & 6,960 \\
\hline $1988 \ldots$ & 90 & 1,700 & 2,029 & 1,280 & 6,440 & 3,176 & 1,730 & 3,260 & 5,205 & 3,010 & 9,700 \\
\hline $1989 \ldots$ & 28 & 1,529 & 2,087 & 1,430 & 5,820 & 1,753 & 800 & 3,120 & 3,840 & 2,230 & 8,940 \\
\hline $1990 \ldots$. & 38 & 1,209 & 1,507 & 870 & 3,210 & 1,908 & 810 & 5,950 & 3,415 & 1,680 & 9,160 \\
\hline $1991 \ldots$ & 32 & 1,060 & 1,624 & 973 & 2,832 & 1,573 & 869 & 8,114 & 3,197 & 1,842 & 10,946 \\
\hline $1992 \ldots$ & 85 & 788 & 935 & 562 & 1,267 & 833 & 502 & 1,162 & 1,768 & 1,064 & 2,429 \\
\hline $1993 \ldots$ & 65 & 455 & 355 & 223 & 983 & 1,665 & 885 & 4,754 & 2,020 & 1,108 & 5,737 \\
\hline $1994 \ldots$. & 9 & 325 & 519 & 341 & 736 & 477 & 316 & 383 & 996 & 657 & 1,119 \\
\hline $1995 \ldots$ & 7 & 259 & 584 & 402 & 790 & 1,728 & 947 & 1,799 & 2,312 & 1,348 & 2,589 \\
\hline $1996 \ldots$ & 36 & 288 & 1,118 & 883 & 1,602 & 3,577 & 2,163 & 5,549 & 4,695 & 3,046 & 7,150 \\
\hline
\end{tabular}

Note: Totals may not equal sum of components because of independent rounding.

Sources: Energy Information Administration: 1987-1995-Uranium Industry Annual 1995 (May 1996). 1996-Form ElA-858, "Uranium Industry Annual Survey" (1996).

Table 2. Expenditures for Exploration and Development of Uranium in the United States, 1987-1996 (Thousand Dollars)

\begin{tabular}{|c|c|c|c|c|c|c|}
\hline \multirow[b]{2}{*}{ Year } & \multirow[b]{2}{*}{$\begin{array}{l}\text { Surface } \\
\text { Drilling }\end{array}$} & \multirow[b]{2}{*}{$\begin{array}{c}\text { Land } \\
\text { Acquisition }\end{array}$} & \multirow{2}{*}{$\begin{array}{l}\text { Other } \\
\text { Exploration and } \\
\text { Development } \\
\text { Expenditures }\end{array}$} & \multirow[b]{2}{*}{$\begin{array}{c}\text { Total U.S. } \\
\text { Expenditures }\end{array}$} & \multicolumn{2}{|c|}{ Foreign Participation } \\
\hline & & & & & Expenditures & $\begin{array}{c}\text { Percent of Total } \\
\text { U.S } \\
\text { Expenditures }\end{array}$ \\
\hline 1987 .............. & 6,960 & 790 & 11,920 & 19,670 & 11,900 & 60 \\
\hline $1988 \ldots . . . . \ldots \ldots$ & 9,700 & 1,670 & 8,730 & 20,100 & 8,900 & 44 \\
\hline $1989 \ldots \ldots \ldots \ldots$ & 8,940 & 390 & 5,430 & 14,770 & 6,100 & 41 \\
\hline $1990 \ldots . . . . . . . .$. & 9,160 & 400 & 7,580 & 17,120 & 2,530 & 15 \\
\hline $1991 \ldots \ldots \ldots . . . .$. & 10,946 & 250 & 6,649 & 17,845 & 3,500 & 20 \\
\hline $1992 \ldots \ldots \ldots \ldots$ & 2,429 & 1,365 & 10,716 & 14,510 & 8,004 & 55 \\
\hline $1993 \ldots \ldots \ldots \ldots$ & 5,737 & 1,024 & 4,509 & 11,270 & 8,527 & 76 \\
\hline 1994 .............. & 1,119 & 71 & 2,464 & 3,654 & 1,864 & 51 \\
\hline 1995 .............. & 2,589 & 69 & 3,350 & $\mathrm{R} 6,009$ & 2,078 & 35 \\
\hline 1996 & 7,150 & 403 & 2,500 & 10,054 & 4,416 & 44 \\
\hline
\end{tabular}

$\mathbf{R}=$ Revised data.

Note: Totals may not equal sum of components because of independent rounding.

Sources: Energy Information Administration: 1987-1995-Uranium Industry Annual 1995 (May-1996). 1996-Form ElA-858, "Uranium Industry Annual Survey" (1996). 
Table 3. Forward-Cost Uranium Reserves by Mining Method, 1996

\begin{tabular}{|c|c|c|c|c|c|c|}
\hline \multirow[b]{3}{*}{ Mining Method } & \multicolumn{6}{|c|}{ Forward-Cost Category } \\
\hline & \multicolumn{3}{|c|}{$\$ 30$ per pound } & \multicolumn{3}{|c|}{$\$ 50$ per pound } \\
\hline & $\begin{array}{c}\text { Ore } \\
\text { (million tons) }\end{array}$ & $\begin{array}{c}\text { Grade } \\
\text { (percent } \mathrm{U}_{3} \mathrm{O}_{8} \text { ) }\end{array}$ & $\begin{array}{c}\mathrm{U}_{3} \mathrm{O}_{8} \\
\text { (million pounds) }\end{array}$ & $\begin{array}{c}\text { Ore } \\
\text { (million tons) }\end{array}$ & $\begin{array}{c}\text { Gradea } \\
\text { (percent } \cup_{3} \mathrm{O}_{8} \text { ) }\end{array}$ & $\begin{array}{c}\mathrm{U}_{3} \mathrm{O}_{8} \\
\text { (million pounds) }\end{array}$ \\
\hline Underground ................................. & 25 & 0.274 & 139 & 143 & 0.163 & 465 \\
\hline 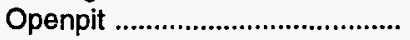 & 10 & 0.139 & 29 & 163 & 0.079 & 257 \\
\hline 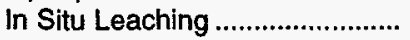 & 45 & 0.132 & 117 & 129 & 0.079 & 202 \\
\hline 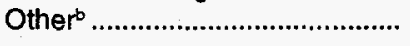 & $<1$ & 0.263 & $<1$ & 15 & 0.050 & 15 \\
\hline 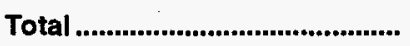 & 80 & 0.178 & 285 & 449 & 0.105 & 939 \\
\hline
\end{tabular}

Weighted average percent $\mathrm{U}_{3} \mathrm{O}_{3}$ per ton of ore.

'Includes heap leach, mine water, and low grade stockpiles.

Notes: Uranium reserves that could be recovered as a byproduct of phosphate and copper mining are not included in this table. Reserves values in forward-cost categories are cumulative: that is, the quantity at each level of forward-cost includes all reserves at the lower costs. Totals may not equal sum of components because of independent rounding.

Sources: Estimated by Energy Information Administration, Office of Coal, Nuclear, Electric and Alternate Fuels, based on industry conferences, U.S. Department of Energy, Grand Junction Projects Office data files, and Energy Information Administration, Form ElA-858, "Uranium Industry Annual Survey" (1996).

Table 4. U.S. Uranium Mine Production and Number of Mines and Sources, 1987-1996

\begin{tabular}{|c|c|c|c|c|c|c|c|c|c|c|}
\hline Mining Method & 1987 & 1988 & 1989 & 1990 & 1991 & 1992 & 1993 & 1994 & 1995 & 1996 \\
\hline $\begin{array}{l}\text { Underground } \\
\text { (thousand pounds } \mathrm{U}_{3} \mathrm{O}_{8} \text { ) }\end{array}$ & 4,900 & 5,400 & 5,300 & $w$ & W & W & 0 & 0 & 0 & W \\
\hline $\begin{array}{l}\text { Openpit } \\
\text { (thousand pounds } \mathrm{U}_{3} \mathrm{O}_{8} \text { ) } \ldots \ldots \ldots \ldots \ldots \ldots \ldots \ldots \ldots \ldots \ldots\end{array}$ & W & W & W & 1,881 & 2,528 & W & 0 & 0 & 0 & 0 \\
\hline $\begin{array}{l}\text { In Situ Leaching } \\
\text { (thousand pounds } \mathrm{U}_{3} \mathrm{O}_{8} \text { ) }\end{array}$ & W & W & $W$ & W & W & W & W & 2,448 & 3,372 & 4,379 \\
\hline $\begin{array}{l}\text { Other }^{\mathrm{a}} \\
\text { (thousand pounds } \mathrm{U}_{3} \mathrm{O}_{8} \text { ) } \ldots \ldots \ldots \ldots \ldots \ldots \ldots \ldots \ldots \ldots \ldots \ldots \ldots\end{array}$ & 1,100 & 4,100 & 4,400 & 3,995 & 2,654 & 986 & 2,050 & 78 & 156 & 326 \\
\hline $\begin{array}{l}\text { Total Mine Production } \\
\text { (thousand pounds } \mathrm{U}_{3} \mathrm{O}_{8} \text { ) }\end{array}$ & 6,000 & 9,500 & 9,700 & 5,876 & 5,182 & 986 & 2,050 & 2,526 & 3,528 & 4,705 \\
\hline 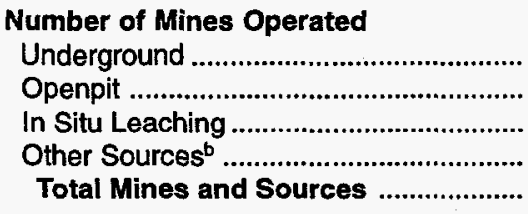 & $\begin{array}{r}19 \\
2 \\
15 \\
1 \\
37\end{array}$ & $\begin{array}{r}17 \\
4 \\
11 \\
0 \\
32\end{array}$ & $\begin{array}{r}19 \\
2 \\
9 \\
2 \\
32\end{array}$ & $\begin{array}{r}27 \\
2 \\
7 \\
3 \\
39\end{array}$ & $\begin{array}{r}6 \\
2 \\
6 \\
1 \\
15\end{array}$ & $\begin{array}{r}4 \\
1 \\
4 \\
8 \\
17\end{array}$ & $\begin{array}{r}0 \\
0 \\
5 \\
7 \\
12\end{array}$ & $\begin{array}{r}0 \\
0 \\
5 \\
7 \\
12\end{array}$ & $\begin{array}{r}0 \\
0 \\
5 \\
7 \\
12\end{array}$ & $\begin{array}{r}1 \\
0 \\
6 \\
6 \\
13\end{array}$ \\
\hline
\end{tabular}

aFor 1987 through 1989, "Other" includes production from openpit, in situ leach, heap leach, mine water, and water-treatment plant solutions. Production quantities were rounded to the nearest 100 thousand pounds. For 1990 and 1991 " "Other" includes production from underground, in situ leach, heap leach (1990), mine water, water treatment plant solutions (1990), and restoration. For 1992, "Other" includes production from underground, apenpit, and in situ leach mines and uranium bearing water from mine workings, tailings ponds, and restoration. For 1993, the "Other" includes production from in situ leach mines and uranium bearing water from mine workings and restoration. For 1994 and 1995, "Other" includes production from uranium bearing water from mine workings and restoration. For 1996, "Other" includes production from an undergrourd mine and uranium bearing water from mine workings and restoration.

'Other Sources includes, in various years, heap leach, mine water, mill site cleanup and mill tailings, well field restoration, and low-grade stockpiles as sources of uranium.

$W=$ Data withheld to avoid disclosure. The data are included in the total for "Other."

Notes: Totals may not equal sum of components because of independent rounding. Table does not include byproduct production and sources.

Sources: Energy Information Administration: 1987-1995-Uranium Industry Annnual 1995 (May 1996); 1996-Form ElA-858, "Uranium Industry Annual Survey" (1996). 
Table 5. U.S. Uranium Concentrate Processing Operations, 1987-1996

\begin{tabular}{|c|c|c|c|c|c|c|c|c|c|c|}
\hline Processing Operations & 1987 & 1988 & 1989 & 1990 & 1991 & 1992 & 1993 & 1994 & 1995 & 1996 \\
\hline Ore Fed to Process ${ }^{a}$ (thousand tons) ....... & 1,441 & 1,214 & 1,235 & 722 & 639 & 256 & 0 & 0 & 167 & 44 \\
\hline Percent $\mathrm{U}_{3} \mathrm{O}_{8}{ }^{b}$ & 0.284 & 0.288 & 0.323 & 0.293 & 0.198 & 0.229 & - & - & 0.520 & 0.500 \\
\hline \multicolumn{11}{|l|}{ Contained $\mathrm{U}_{3} \mathrm{O}_{8}$ (thousand pounds) } \\
\hline Other Feed Materials ${ }^{\mathrm{c}}$ & 474 & 507 & 429 & 485 & 179 & 181 & 42 & 78 & 163 & 409 \\
\hline Total Mill Feed (thousand pounds $\mathrm{U}_{3} \mathrm{O}_{8}$ ) & 8,664 & 7,505 & 8,406 & 4,712 & 2,708 & 1,353 & 42 & 78 & 1,902 & 853 \\
\hline $\begin{array}{l}\text { In-Process Inventory Change } \\
\text { (thousand pounds } \mathrm{U}_{3} \mathrm{O}_{8} \text { ) }\end{array}$ & -210 & 136 & -234 & -244 & -122 & -25 & 10 & 24 & 157 & -137 \\
\hline \multicolumn{11}{|l|}{$\begin{array}{l}\text { Concentrate Produced at Mills } \\
\text { (thousand pounds } \mathrm{U}_{3} \mathrm{O}_{8} \text { ) }\end{array}$} \\
\hline 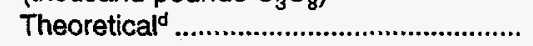 & 8,874 & 7,369 & 8,640 & 4,956 & 2,830 & 1,377 & 31 & 54 & 1,744 & 990 \\
\hline 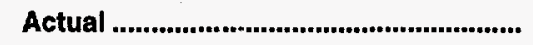 & 8,536 & 7,034 & 8,175 & 4,649 & 2,608 & 1,359 & 30 & 46 & 1,615 & 860 \\
\hline Recovery as Percent of Total Mill Feed .... & 96.2 & 95.5 & 94.6 & 93.8 & 92.2 & 98.7 & - & - & 92.6 & 86.8 \\
\hline $\begin{array}{l}\text { Tailings and Unaccountable. } \\
\text { (thousand pounds } \mathrm{U}_{3} \mathrm{O}_{8} \text { ) }\end{array}$ & 338 & 335 & 465 & 307 & 222 & 18 & 1 & 8 & 130 & 130 \\
\hline \multicolumn{11}{|l|}{ Other Processing $^{\bullet}$} \\
\hline 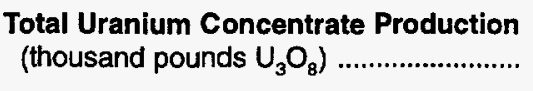 & 12,991 & 13,130 & 13,837 & 8,886 & 7,952 & 5,645 & 3,063 & 3,352 & 6,043 & 6,321 \\
\hline $\begin{array}{l}\text { Total Concentrate Shipped From Mills } \\
\text { and Plants }\end{array}$ & & & & & & & & & & \\
\hline 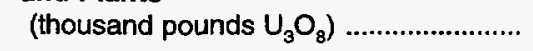 & 11,558 & 12,791 & 14,808 & 12,957 & 8,437 & 6,853 & 3,374 & 6,319 & 5,500 & 5,982 \\
\hline
\end{tabular}

"Uranium ore "fed to process" in any year can include: ore mined and shipped to a mill during the same year, ore that was mined during a prior year and later shipped from mine-site stockpiles, and/or ore obtained from drawdowns of stockpiles maintained at a mill site.

bWeighted average percent $\mathrm{U}_{3} \mathrm{O}_{8}$ per ton of ore.

Includes for various years uranium from low-grade ore, mill cleanup, mine water, tailings water, and heap leaching, except as footnoted below.

At 100-percent recovery.

- $\mathrm{U}_{3} \mathrm{O}_{\mathrm{a}}$ concentrate production from in situ leaching and as a byproduct of other processing. The totals for 1987 through 1988 include $\mathrm{U}_{3} \mathrm{O}_{8}$ recovered from reclamation and mine water at some mills that did not report processing of uranium ore for those years.

-=Not applicable.

Note: Totals may not equal sum of components because of independent rounding.

Sources: Energy Information Administration: 1987-1995-Uranium Industry Annnual 1995 (May 1996); 1996-Form ElA-858, "Uranium Industry Annual Survey" (1996). 
Table 6. Operating Status of Conventional Uranium Mills, End of the Year, 1993-1996

\begin{tabular}{|c|c|c|c|c|c|c|}
\hline \multirow[b]{2}{*}{ Mill Owner } & \multirow[b]{2}{*}{ Name and State } & \multirow{2}{*}{$\begin{array}{l}\text { Milling Capacity } \\
\text { (short tons of ore } \\
\text { per day) }\end{array}$} & \multicolumn{4}{|c|}{ Operating Status at End of the Year } \\
\hline & & & 1993 & 1994 & 1995 & 1996 \\
\hline 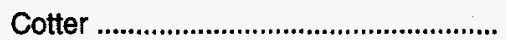 & Canon City (CO) & 1,200 & $\mathbf{I}$ & 1 & $\mathbf{I}$ & I \\
\hline 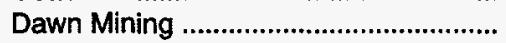 & Ford (WA) & 450 & $i$ & $i$ & i & 1 \\
\hline 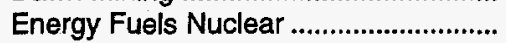 & White Mesa (UT) & 2,000 & $i$ & i & 0 & i \\
\hline Green Mountain Mining Venture ............ & Sweetwater (WY) & 3,000 & 1 & 1 & 1 & 1 \\
\hline 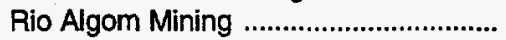 & Ambrosia Lake (NM) & 7,000 & 1 & 1 & 1 & 1 \\
\hline U.S. Energy/Plateau Resources ............ & Shootaring (UT) & b750 & 1 & 1 & I & 1 \\
\hline
\end{tabular}

Summary of Mill Status

Number of Mills

Operating ${ }^{\mathfrak{c}}$

Inactive.

Total

\section{Available Milling Capacity}

Operating (tons of ore per day)

Inactive (tons of ore per day)

Total Available Capacity

(tons of ore per day)

Average Daily Mill Feed

(tons of ore per day)

Percent of Total Available Capacity ${ }^{\circ} . . . .$.

--
--
-

--

$\begin{array}{lll}0 & \\ 6 & 6\end{array}$

$\begin{array}{lll}0 & 1 & 0 \\ 6 & 5 & 6 \\ 6 & 6 & 6\end{array}$

aMilling capacity based on historical data and data reported on Form EIA-858 for 1996.

'For 1993 through 1994, Shootaring's capacity was 1,000 short tons of ore per day.

Number of mills being operated to process uranium at the end of year.

dRounded value. Based on $\mathbf{3 5 0}$ workdays per year and total ore fed to process during the year shown in Table 5.

"Rounded value. Calculated based on ore fed to process (Table 5) during 350 workdays per year.

$O=$ Operating at the end of the year; $I=$ Inactive at the end of the year.

$=$ Not applicable.

Sources: Energy Information Administration: 1993-1995-Uranium Industry Annual 1995 (May 1996). 1996-Form ElA-858, "Uranium Industry Annual Survey" (1996).

Table 7. Operating Status of Nonconventional Uranium Plants, 1996

\begin{tabular}{|c|c|c|c|c|}
\hline Plant Owner & Name and State & Plant Type & $\begin{array}{c}\text { Rated Capacity } \\
\text { (thousand pounds } \\
\mathrm{U}_{3} \mathrm{O}_{8} \text { per year) }\end{array}$ & $\begin{array}{c}\text { Operating Status } \\
\text { at the End of } \\
\text { the Year }\end{array}$ \\
\hline Converse County Mining Venture ..... & Highland (WY) & In Situ Leach & 2,000 & 0 \\
\hline 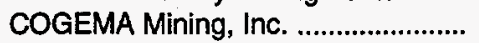 & West Cole (TX) & In Situ Leach & 200 & 1 \\
\hline 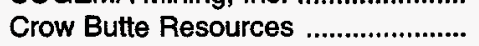 & Crow Butte (NE) & In Situ Leach & 1,000 & 0 \\
\hline Everest Minerals & Hobson (TX) & In Situ Leach & 1,000 & 1 \\
\hline 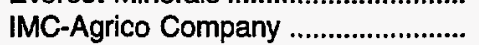 & Sunshine Bridge (LA) & Phosphate Byproduct & 420 & 0 \\
\hline 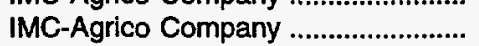 & Uncle Sam (LA) & Phosphate Byproduct & 750 & 0 \\
\hline 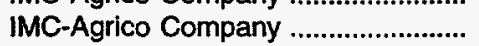 & Plant City (FL) & Phosphate Byproduct & 608 & 1 \\
\hline 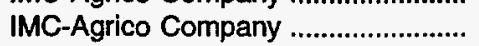 & New Wales (FL) & Phosphate Byproduct & 750 & 1 \\
\hline 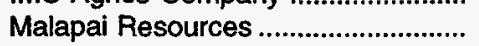 & Christensen Ranch (WY) & In Situ Leach & 650 & 0 \\
\hline 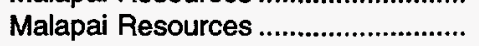 & Holiday-EI Mesquite (TX) & In Situ Leach & 600 & I \\
\hline Malapai Resources ................................. & Irigaray $(\mathrm{WY})$ & In Situ Leach & 350 & 1 \\
\hline 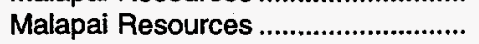 & O'Hern (TX) & In Situ Leach & ${ }^{\circ} 0$ & 1 \\
\hline 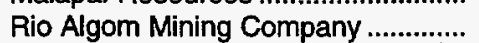 & Smith Ranch (WY) & In Situ Leach & 250 & $i$ \\
\hline Uranium Resources, Inc. .................... & Kingsville Dome (TX) & In Situ Leach & 1,300 & 0 \\
\hline Uranium Resources, Inc. ..................... & Rosita (TX) & In Situ Leach & 1,000 & 0 \\
\hline
\end{tabular}

Milling capacity based on data reported on Form EIA-858 for 1996.

$\triangle O=O p e r a t i n g$ at the end of the year; I=Inactive at the end of the year.

'Malapai Resources did not report a rated capacity for the O'Hern plant.

Note: Pathfinder Mines, Inc. has been granted a commercial license for its North Butte-Ruth in situ leach project in Campbell County, Wyoming.

Source: Energy Information Administration, Form ElA-858, "Uranium Industry Annual Survey" (1996). 
Table 8. Employment in the U.S. Uranium Industry by Category, 1987-1996 (Person-Years)

\begin{tabular}{|c|c|c|c|c|c|c|}
\hline \multirow[b]{2}{*}{ Year } & \multicolumn{5}{|c|}{ Employment Categories } & \multirow[b]{2}{*}{ Total } \\
\hline & Exploration & Mining & Milling & Processing & Reclamation ${ }^{a}$ & \\
\hline $1987 \ldots . .$. & 183 & 819 & 432 & 568 & NA & 2,002 \\
\hline $1988 \ldots . .$. & 144 & 849 & 572 & 576 & NA & 2,141 \\
\hline 1989 & 86 & 659 & 367 & 471 & NA & 1,583 \\
\hline $1990 \ldots . .$. & 73 & 664 & 304 & 293 & NA & 1,335 \\
\hline $1991 \ldots . .$. & 52 & 411 & 191 & 361 & NA & 1,016 \\
\hline $1992 \ldots . .$. & 51 & 219 & 129 & 283 & NA & 682 \\
\hline $1993 \ldots .$. & 36 & 133 & 65 & 145 & 491 & 871 \\
\hline $1994 \ldots .$. & 41 & 157 & 105 & 149 & 528 & 980 \\
\hline $1995 \ldots .$. & 27 & 226 & 121 & 161 & 573 & 1,107 \\
\hline $1996 \ldots$ & 27 & 333 & 155 & 175 & 429 & 1,118 \\
\hline
\end{tabular}

"Data on reclamation employment was not collected prior to 1993.

NA = Not available.

Note: Totals may not equal sum of components because of independent rounding

Sources: Energy Information Administration: 1987-1995-Uranium Industry Annual 1995 (May 1996); 1996-Form ElA-858, "Uranium Industry Annual Survey" (1996).

Table 9. Employment in the U.S. Uranium Industry by State, 1996 (Person-Years)

\begin{tabular}{|c|c|c|}
\hline State(s) & Total & Percent of Total \\
\hline 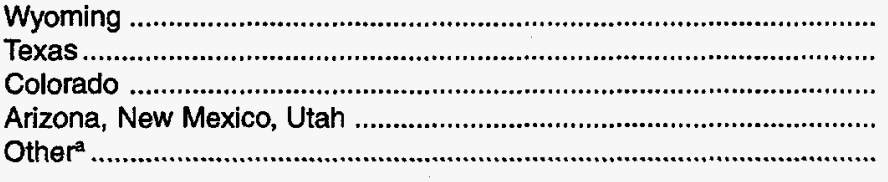 & $\begin{array}{l}337 \\
280 \\
140 \\
170 \\
191\end{array}$ & $\begin{array}{l}30 \\
25 \\
13 \\
15 \\
17\end{array}$ \\
\hline 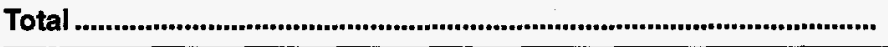 & 1,118 & 100 \\
\hline
\end{tabular}

ancludes Florida, Louisiana, Nevada, Washington.

Notes: Totals may not equal sum of components because of independent rounding. Total employment includes 429 person years for reclamation. Source: Energy Information Administration, Form EIA-858, "Uranium Industry Annual Survey" (1996). 


\section{Uranium Marketing Activities in the United States}

\section{Introduction}

Movement of both natural and enriched uranium materials illustrates, for 1996, the normal market mechanisms used by U.S. suppliers and utilities to procure and dispose of uranium (Figure 8). The uranium quantities throughout this chapter are expressed as $\mathrm{U}_{3} \mathrm{O}_{8}$ equivalent $\left(\mathrm{U}_{3} \mathrm{O}_{8} \mathrm{e}\right)$. U.S. utilities acquire uranium each year both from domestic suppliers (domestic purchases) and foreign suppliers (foreign purchases).

Domestic suppliers are U.S.-based firms that exchange, loan, purchase, or sell uranium, and are not domestic electric utilities. They can include uranium brokers, converters, enrichers, fabricators, traders, producers, and uranium property holders. Foreign suppliers and foreign utilities are non-U.S. based firms that market uranium into and from the United States.

Uranium market activities of domestic utilities include purchases from both domestic and foreign suppliers of uranium from domestic and foreign sources, contracting for future supplies, and anticipated uranium requirements of U.S. utilities. In addition, this chapter also presents enrichment activities, the amount of uranium loaded into reactors, total levels of imports and exports, purchases by U.S. brokers and traders, and the year-end 1996 status of uranium inventories in the United States.

\section{Uranium Market Activity of U.S. Utilities}

\section{Uranium Purchases}

In 1996, U.S. utilities received a total of 47.3 million pounds $\mathrm{U}_{3} \mathrm{O}_{8} \mathrm{e}$ (Figure 9). Of the 47.3 million pounds, the actual quantity delivered with a report price was 46.6 million pounds $\mathrm{U}_{3} \mathrm{O}_{8} \mathrm{e}$, and the average price was $\$ 14.12$ per pound (Table 10 and Figure 10). Compared with 1995, the quantity is an increase of 9 percent. Foreign-origin uranium accounted for 39.0 million pounds ( 82 percent) of the deliveries (Figure 11) at an average price of $\$ 14.02$ per pound (Table 11). Approximately 40 percent of all uranium received by U.S. utilities was Canadian origin
(Table 12 ), while only 18 percent was domestically produced. In rank order, the next three foreign country origins were Russia (11 percent), Australia (10 percent), and Uzbekistan (7 percent) (Figure 12).

The 28 firms that delivered uranium to the utilities are shown in the following list. Fourteen of the 28 firms (designated with an asterisk) made deliveries under purchase contracts signed in 1996.

\section{Uranium Sellers to U.S. Utilities}

British Nuclear Fuel Ltd. (BNFL)*

Cameco Corporation*

COGEMA, Inc.

COGEMA Mining, Inc.

Energy Fuels Corporation

Energy Resources of Australia

Everest Exploration, Inc.

Geomex Minerals, Inc.

Global Nuclear Supply Service Ltd.*

Malapai Resources Company

Nordostschweizerische Kraftwerke*

Nuclear Fuel Resources, Inc.*

Nuexco Trading Corporation

Nuclear Fuels Corporation of South Africa*

NUKEM, Inc.*

Olympic Dam Corporation

Power Resources, Inc.*

Rio Algom Mining Corporation*

Sheep Mountain Partners

Siemens Nuclear Power Corporation

The Uranium Exchange Company*

U.S. Energy Corporation

U.S. Enrichment Corporaton (USEC)*

UG U.S.A., Inc.*

Uranerz Exploration \& Mining Ltd.*

Uranerz U.S.A., Inc.

Urangesellschaft Mbh

Uranium Resources, Inc.*

The utilities purchased uranium of several material types (Table 13). Uranium concentrate $\left(\mathrm{U}_{3} \mathrm{O}_{8}\right)$ accounted for 83 percent of the purchases, uranium hexafluoride $\left(\mathrm{UF}_{6}\right)$ was 12 percent, and enriched uranium was 5 percent (Figure 13). 
Purchases of uranium (both U.S. and foreign-origin) from domestic suppliers by domestic utilities in 1996 totaled 22.9 million pounds $\mathrm{U}_{3} \mathrm{O}_{8} \mathrm{e}, 0.6$ million pounds more than the deliveries for 1995 (Table 14). The average price of these domestic purchases in 1996 was $\$ 13.81$ per pound.

Purchases of uranium (only foreign-origin) from foreign suppliers by U.S. utilities in 1996 totaled 23.7 million pounds $\mathrm{U}_{3} \mathrm{O}_{8} \mathrm{e}, 2.5$ million pounds more than the deliveries for 1995. The average price of these foreign purchases in 1996 was $\$ 14.41$ per pound.

\section{Uranium Price Distributions and Contract Types}

A pricing mechanism was reported for each price of a uranium delivery. One mechanism, contract-specified, was dominant for deliveries in 1995 and 1996, whereas, the market-related with no floor pricing mechanism was prevalent in 1994 (Table 14).

While average prices of uranium had risen by 26 percent from its 1995 level of $\$ 11.25$ per pound to $\$ 14.12$ per pound in 1996, the range of prices from highest to lowest was more narrow in 1996 (Table 15).

During 1996, 59 percent of the deliveries to utilities involved purchases under spot and long-term arrangements (Figure 14). The average price for spot purchases was $\$ 14.22$ per pound, and for long-term purchases was $\$ 14.74$ per pound (Table 16).

\section{New Uranium Purchases}

The quantity of uranium delivered in 1996, under 52 purchase contracts signed in 1996, was 12.6 million pounds $\mathrm{U}_{3} \mathrm{O}_{8} \mathrm{e}$, and the average price was $\$ 14.35$ per pound (Table 17). Of this quantity, 39 new spot contracts accounted for 6.9 million pounds in 1996.

Future deliveries reported for 1997 through 2006, for contracts signed in 1996, total 57.4 million pounds. Of this quantity, firm deliveries amount to 50.3 million pounds (Table 18).

\section{Anticipated Uranium Market Requirements}

Future deliveries for 1997-2006, based on contracts reported in effect at the end of 1996, for all purchase contracts consisted of 146.6 million pounds for firm deliveries and 40.9 million pounds for optional deliveries (Table
19). Foreign suppliers have contracts for 58 percent of the existing firm deliveries to utilities through 2006 (Figure 15 and Table 19).

At the end of 1996, cumulative unfilled uranium requirements for commercial nuclear reactors for 1997 through 2006 were reported to be 306.2 million pounds $\mathrm{U}_{3} \mathrm{O}_{8} \mathrm{e}$ (Table 20). The quantity of firm and optional deliveries of uranium for the same period under existing purchase contracts totaled 187.5 million pounds (Table 21). The contracted deliveries and unfilled requirements combined represent the U.S. utilities anticipated market requirements of uranium. The total 10-year requirements of U.S. utilities, at the end of 1996, was 493.7 million pounds.

The unfilled requirements category, as reported at the end of 1996, constitutes a small portion of anticipated market requirements in 1997 (Figure 16). However, it increases to 41 percent of total anticipated requirements by 2000 and to 97 percent by 2006. For the years 1997 through 2000 it would appear that utilities meet all of their reported feed deliveries to uranium enrichers by their contracted and unfilled requirements, i.e. anticipated market requirement (Figure 17). However, for 2001 through 2006, the utilities' reported enrichment feed deliveries are less than their anticipated market requirements, indicating perhaps a period of uranium inventory buildup or an increase in purchases of enriched uranium product because utilities anticipate to receive more uranium than they expect to send to enrichers.

\section{Uranium Enrichment Activities}

\section{Uranium Feed for Enrichment}

In 1996, U.S. utilities delivered 49.1 million pounds $\mathrm{U}_{3} \mathrm{O}_{8} \mathrm{e}$ of natural uranium feed to domestic and foreign enrichment suppliers (Table 22). U.S.-origin uranium accounted for 9.0 million pounds ( 18 percent) of the feed deliveries (Table 23). Deliveries to the United States Enrichment Corporation (USEC) enrichment plants accounted for 38.7 million pounds, or 79 percent of the total.

A total of 10.4 million pounds of uranium feed was delivered to foreign enrichment plants in 1996. It represented 21 percent of total feed deliveries in 1996, compared with 23 percent in 1995.

At the end of 1996, the U.S. utilities reported that the amount of natural uranium feed to be shipped for enrichment for the years 1997 through 2006 will vary between 33 million and 50 million pounds annually (Table 24). 
The total 10-year quantity of natural uranium that utilities expect to send for enrichment is reported at the end of 1996 to be 8.7 million pounds higher than the quantity reported at the end of 1995 for the same period.

\section{Purchases of Enrichment Services}

In 1996, 11.2 million separative work units (SWU) were purchased by U.S. utilities under enrichment services contracts (Table 25.) USEC provided 72 percent of the utilities' SWU and foreign enrichers the remaining 28 percent. In comparison in 1995, U.S. enrichment plants provided 71 percent of the utilities' enrichment needs.

The 7 firms that were reported as the sellers of enrichment services for these SWU deliveries in 1996 are shown in the following list.

\section{Enrichment Service Sellers to U.S. Utilities}

COGEMA, Inc.

Global Nuclear Supply Service, Ltd.

NUKEM, Inc.

Siemens Power Corp.

UG U.S.A., Inc.

United States Enrichment Corporation (USEC)

Urenco

The long-term enrichment service contracts were dominant in 1996, and represented 88 percent of SWU deliveries and were provided at both U.S. and foreign enrichment plants (Table 26). In contrast, uranium enrichment under spot contracts represents only 4 percent of SWU deliveries.

\section{Fuel Assemblies}

The total amount of uranium contained in fuel assemblies loaded into U.S. commercial nuclear reactors during 1996 was 45.5 million pounds $\mathrm{U}_{3} \mathrm{O}_{8} \mathrm{e}$ (Table 27). This was 5.7 million pounds less than in 1995 (Figure 18). These quantities do not include uranium in fuel assemblies removed from reactors that may be reloaded later.

\section{Imports}

In $1996,45.4$ million pounds $\mathrm{U}_{3} \mathrm{O}_{8}$ e was delivered to U.S. suppliers and U.S. utilities from foreign suppliers in 1996 (Table 28). The average price for the foreign purchases was $\$ 13.15$ per pound $\mathrm{U}_{3} \mathrm{O}_{8} \mathrm{e}$. This is 29 percent higher than the 1995 average import price of $\$ 10.20$ per pound.

\section{Purchases by U.S. Brokers and Traders}

In 1996, U.S. brokers and traders received 25.3 million pounds $\mathrm{U}_{3} \mathrm{O}_{8} \mathrm{e}$ of uranium at an average price of $\$ 12.61$ per pound (Table 29). Brokers and traders received 4.7 million pounds of U.S.-origin uranium and 20.5 million pounds of foreign origin. Most of the uranium (17.8 million pounds or 71 percent) was from foreign suppliers. In 1995 , by comparison, U.S. brokers and traders received 22.9 million pounds $\mathrm{U}_{3} \mathrm{O}_{8} \mathrm{e}$ at an average price of $\$ 9.53$ per pound (Figure 19).

\section{Exports}

In 1996, uranium deliveries exported to foreign suppliers and foreign utilities was 11.5 million pounds $\mathrm{U}_{3} \mathrm{O}_{8} \mathrm{e}, 17$ percent more than in 1995, and the average price was $\$ 14.20$ per pound, 5 percent more than in 1995 (Table 30 and Figure 20). Of the exported uranium, 57 percent was foreign-origin and 43 percent was U.S.-origin. U.S. brokers and traders sold 6.0 million pounds at an average export price of $\$ 12.82$ per pound in 1996 .

\section{Uranium Inventories}

Total commercial inventories of all material types, as of December 31,1996 , were 81.2 million pounds $\mathrm{U}_{3} \mathrm{O}_{8} \mathrm{e}$, an increase of 8.7 million pounds compared with the end of 1995 (Table 31). U.S. utility inventories increased by 8.8 million pounds or 15 percent (Figure 21), and enriched uranium gained the most (Figure 22). U.S. supplier inventories totaled 13.7 million pounds at the end of 1995 , a decrease of less than 1 percent. The DOE and USEC inventories of uranium totaled 107.7 million pounds at year-end 1996, a decrease of 3 percent.

Uranium concentrate inventories on hand, in storage, or at conversion plants at the end of 1996 were 37.1 million pounds $\mathrm{U}_{3} \mathrm{O}_{8}$ (Table 32), between 6 and 8 percent more than at the end of 1995 and 1994, respectively. U.S. producers' concentrate inventories totaled 5.9 million pounds (Table 33). Compared with 1995, producer inventories decreased by less than 1 percent. During 1996, U.S. brokers and traders commercial inventories declined 0.3 million pounds to 6.6 million pounds. 


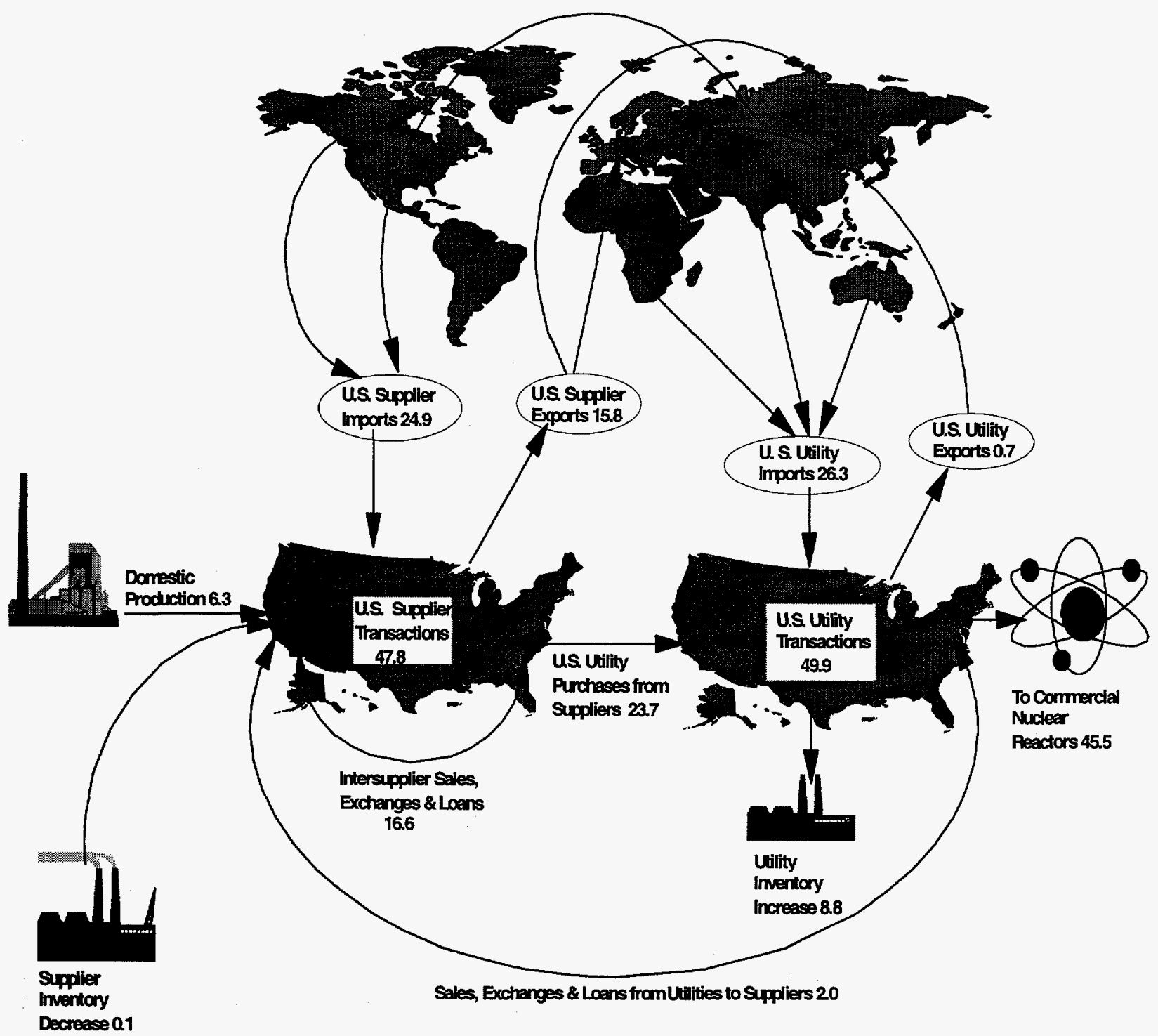

Notes: Quantities are in million pounds $\mathrm{U}_{3} \mathrm{O}_{3}$ equivalent. Imports and exports include uranium from purchases, sales, and net inflows or outflows from exchanges and loan transactions.

Source: Prepared by the Energy Information Administration, Office of Coal Nuclear, Electric and Alternate Fuels, based on data reported on Form EIA858 for 1996. 
Figure 9. Quantity of U.S. Utilities Purchases of Uranium by Supplier and Delivery Year, 1994-1996

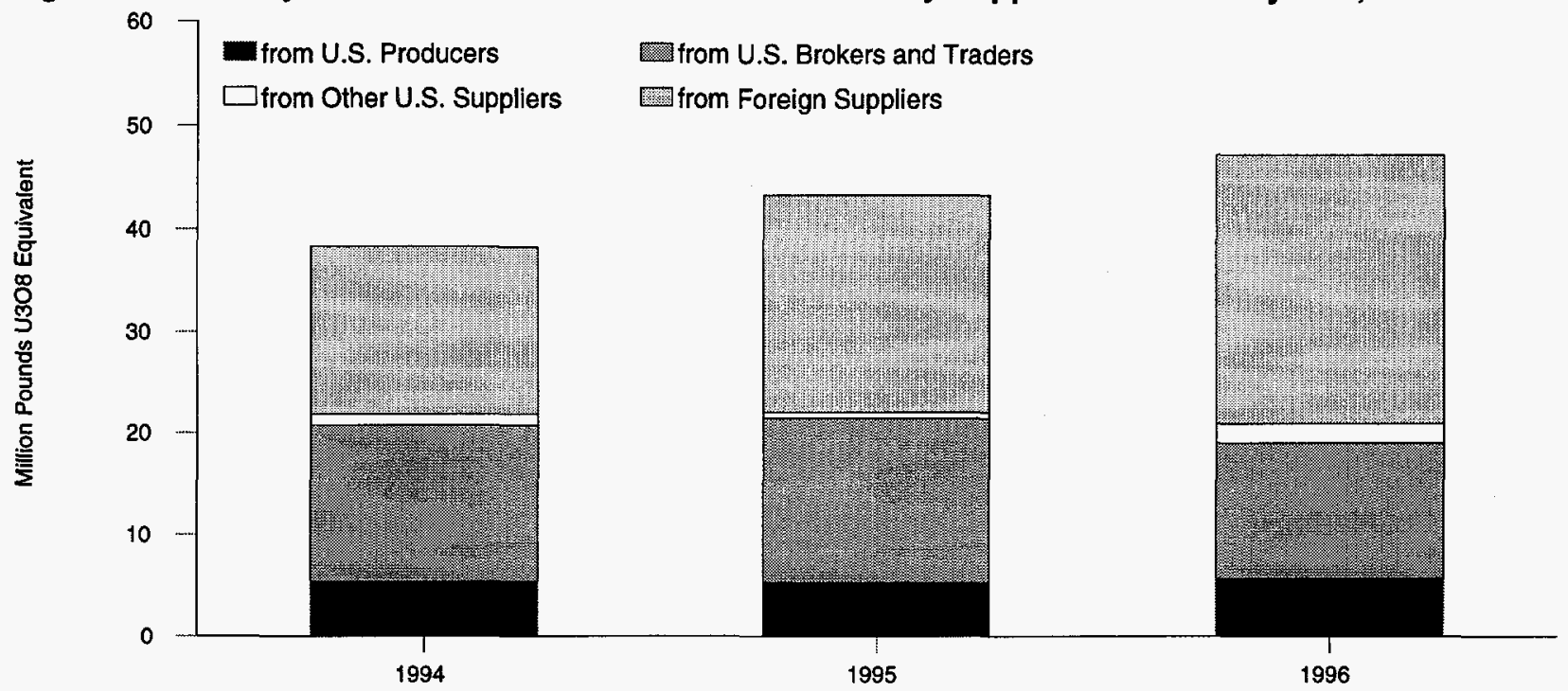

Figure 10. Weighted-Average Price of U.S. Utilites Purchases of Uranium by Supplier and Delivery Year, 1994-1996

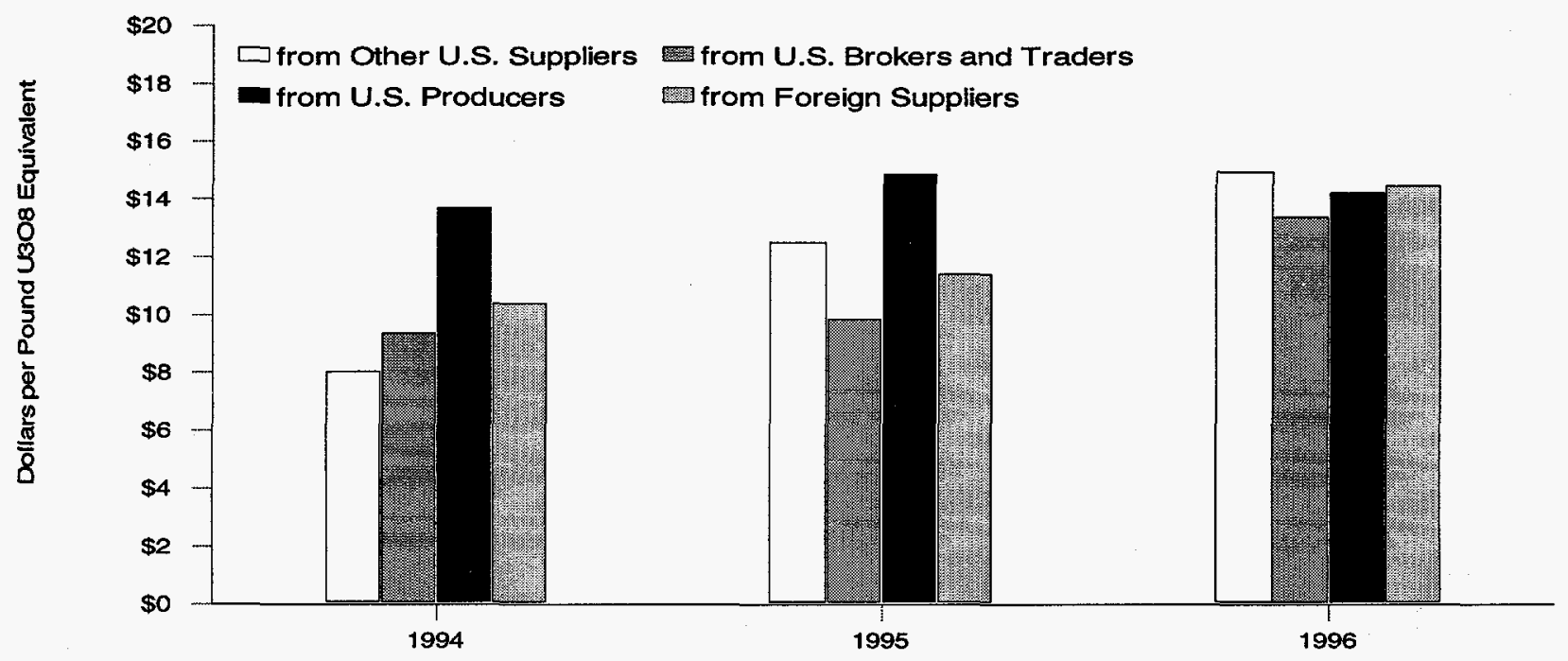

Figure 11. Quantity of U.S. Utilities Purchases of Uranium by Origin and Delivery Year, 1994-1996

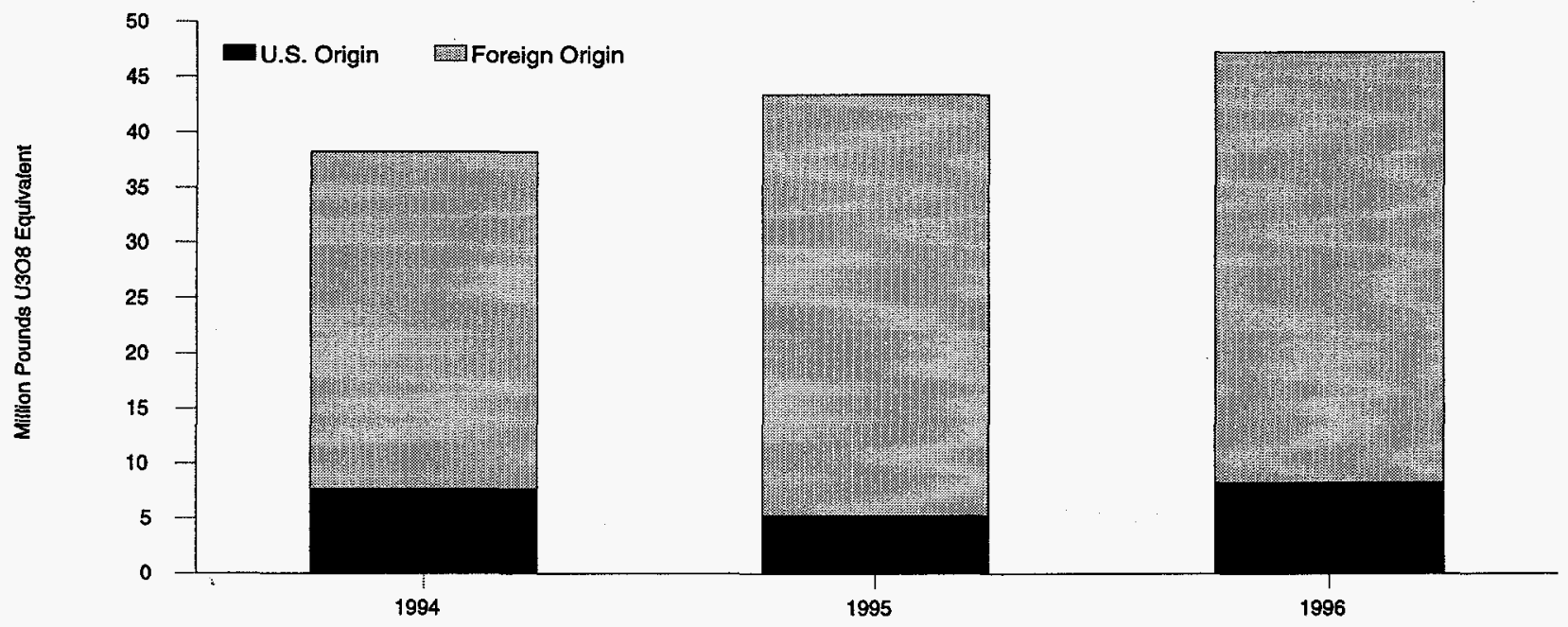

Source: Energy Information Administration, Form ElA-858, "Uranium Industry Annual Survey" (1994-1996). 
Figure 12. U.S. Utilities Purchases of Uranium by Selected Country Origin and Delivery Year, 1994-1996

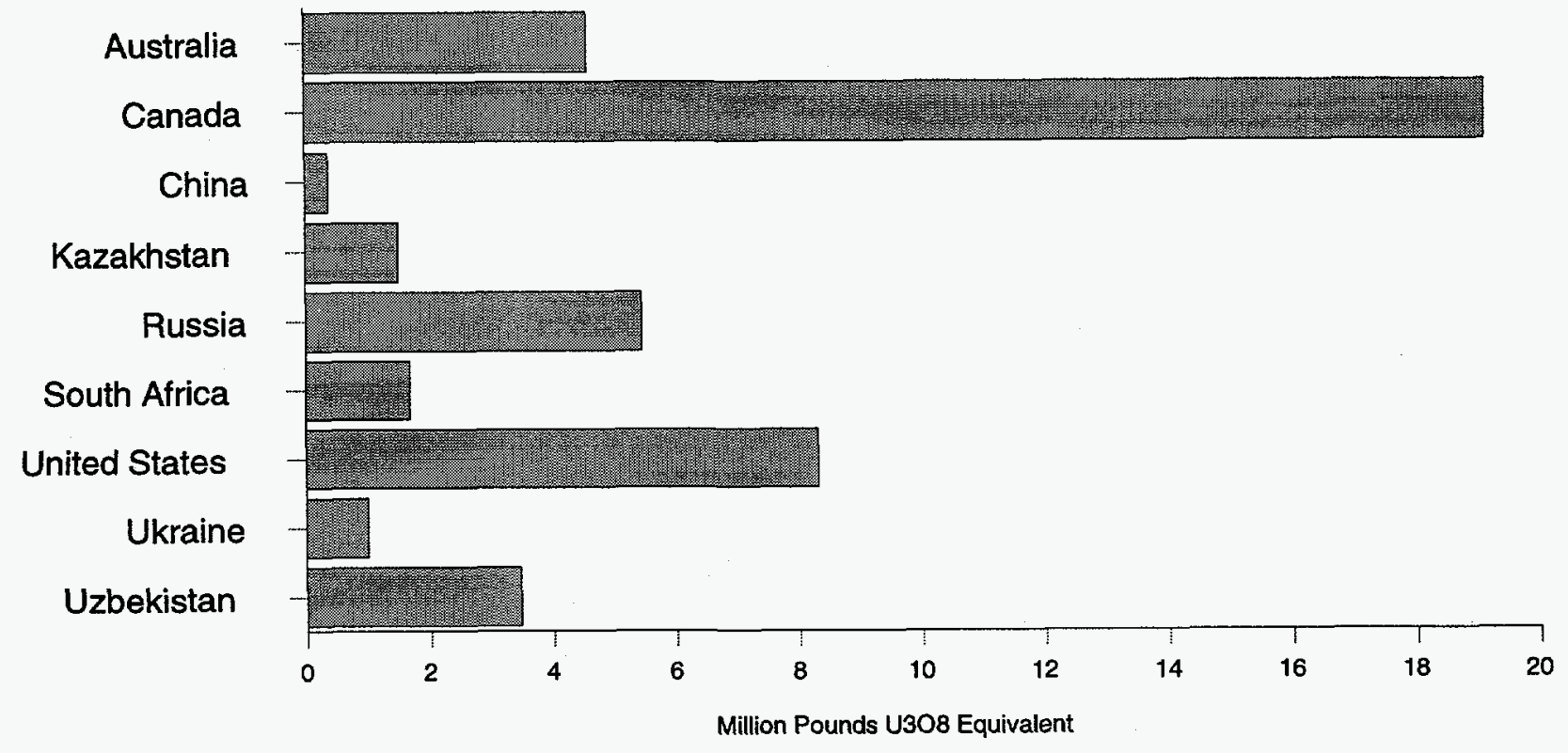

Figure 13. U.S. Utilities Purchases of Uranium by Material Type and Delivery Year, 1994-1996

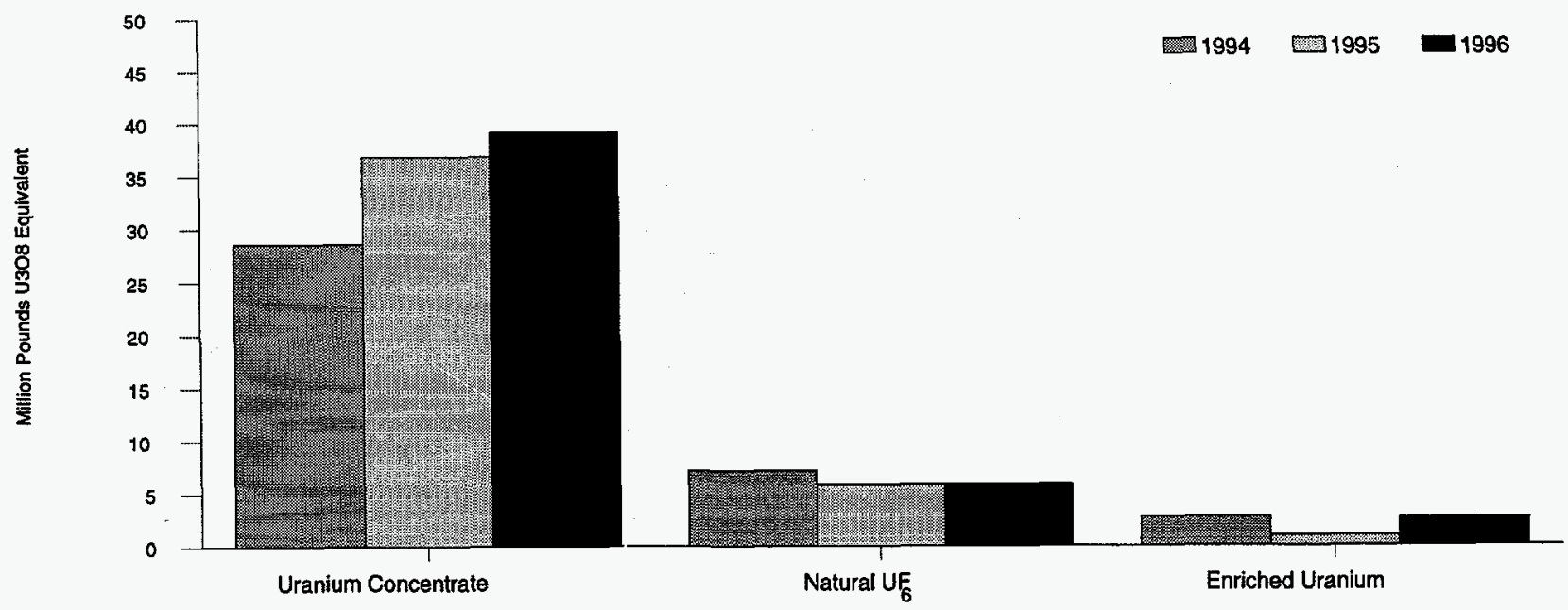

Figure 14. U.S. Utilities Purchases of Uranium by Contract Type and Material Type, 1996 Deliveries

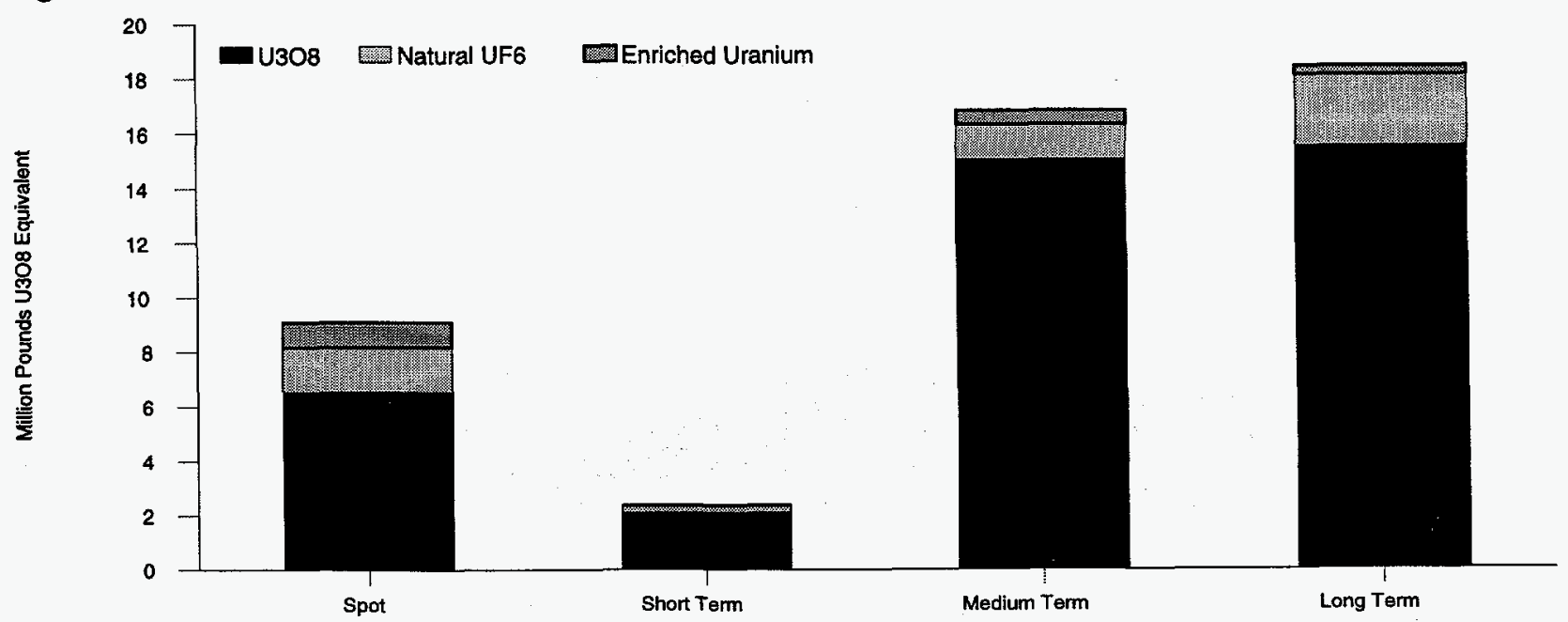

Source: Energy Information Administration, Form ElA-858, "Uranium Industry Annual Survey" (1994-1996). 
Figure 15. U.S. Utilities Contracted Purchases of Uranium by Supplier, Firm Deliveries, and Delivery Year, 1997-2006

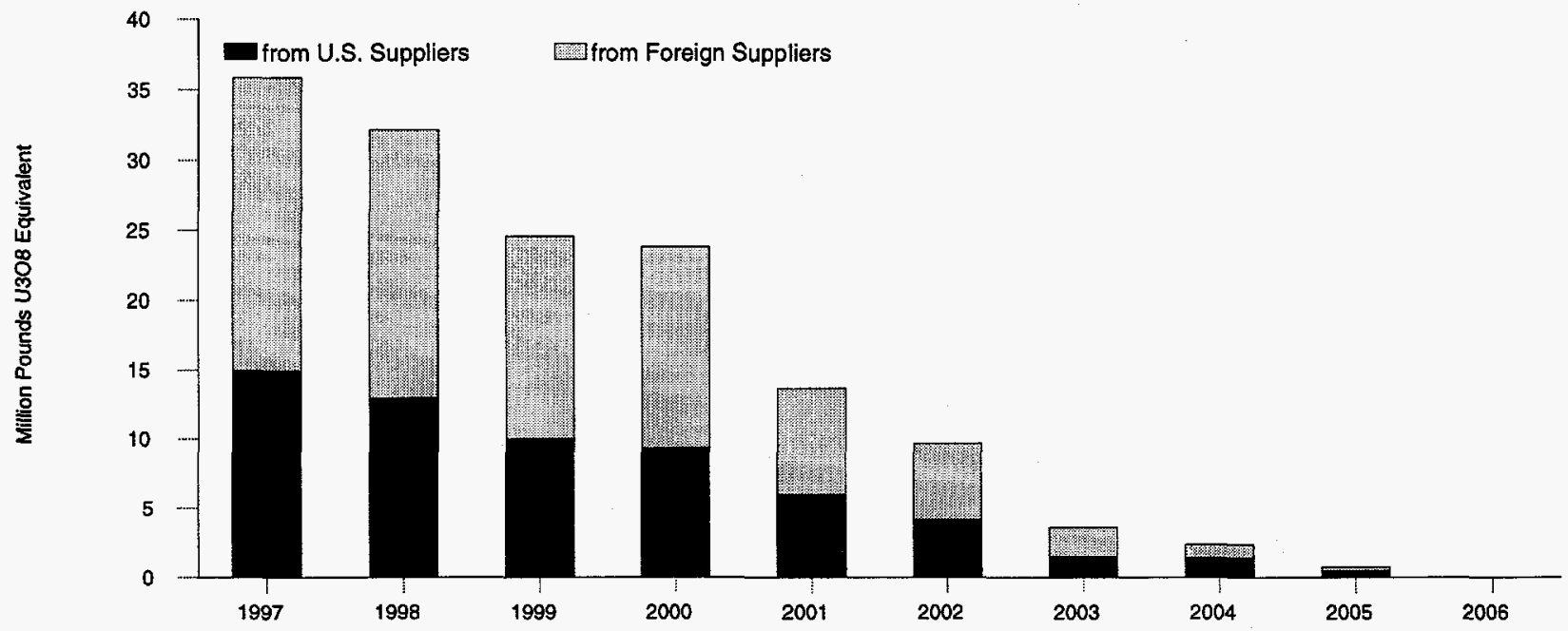

Figure 16. U.S. Utilities Annual Unfilled Uranium Requirements, 1997-2005

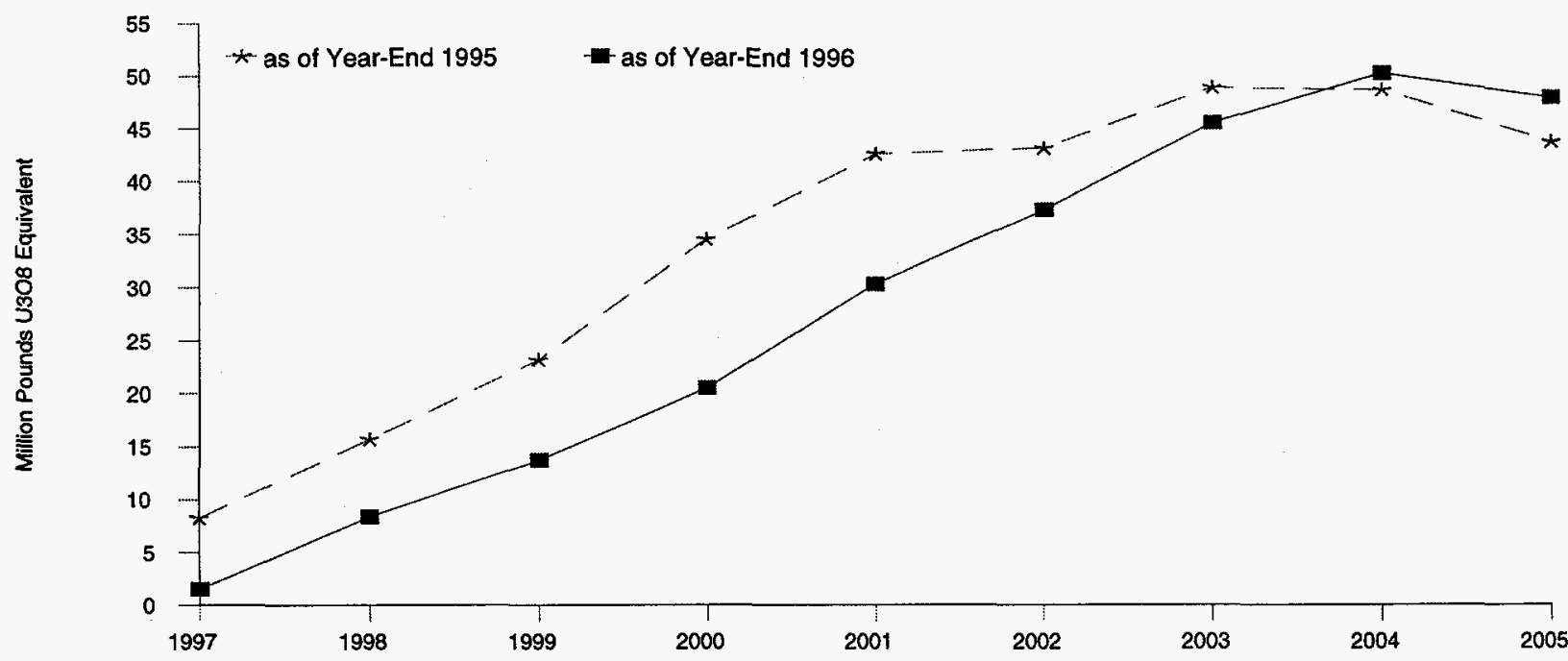

Figure 17. Anticipated Uranium Market Requirements of U.S. Utilities, 1997-2006

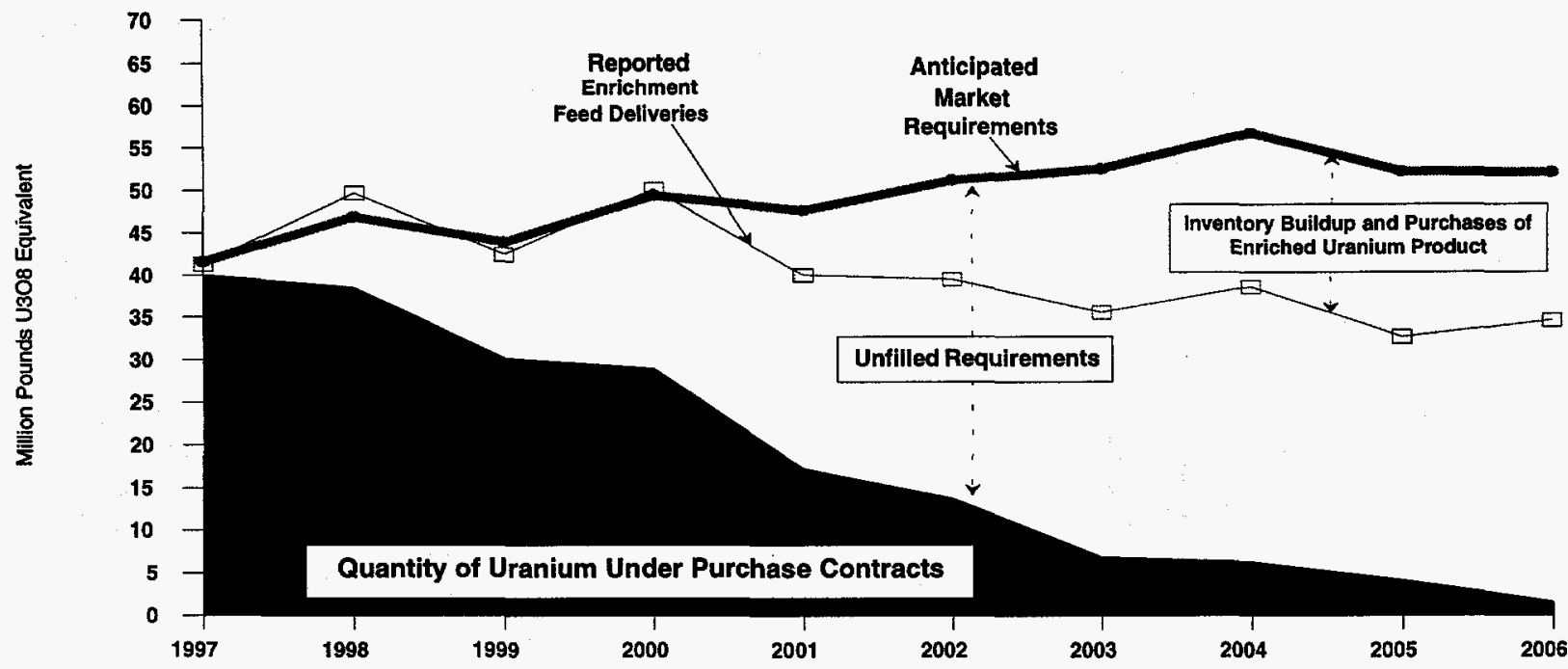

Source: Energy Information Administration, Form EIA-858, "Uranium Industry Annual Survey" (1996). 
Figure 18. Uranium in Fuel Assemblies Loaded into U.S. Commercial Nuclear Reactors by Year, 1994-1996

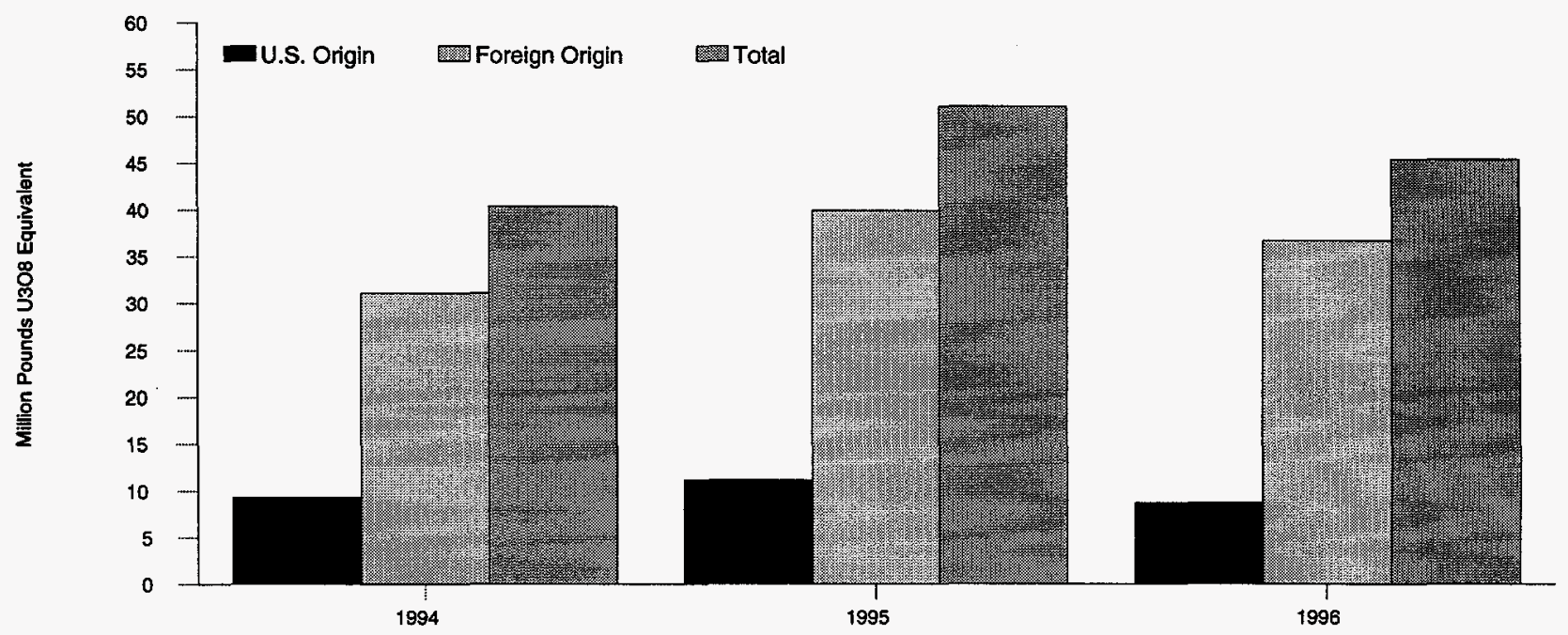

Figure 19. U. S. Brokers and Traders Purchases of Uranium by Quantity, Weighted-Average Price, and Delivery Year, 1994-1996

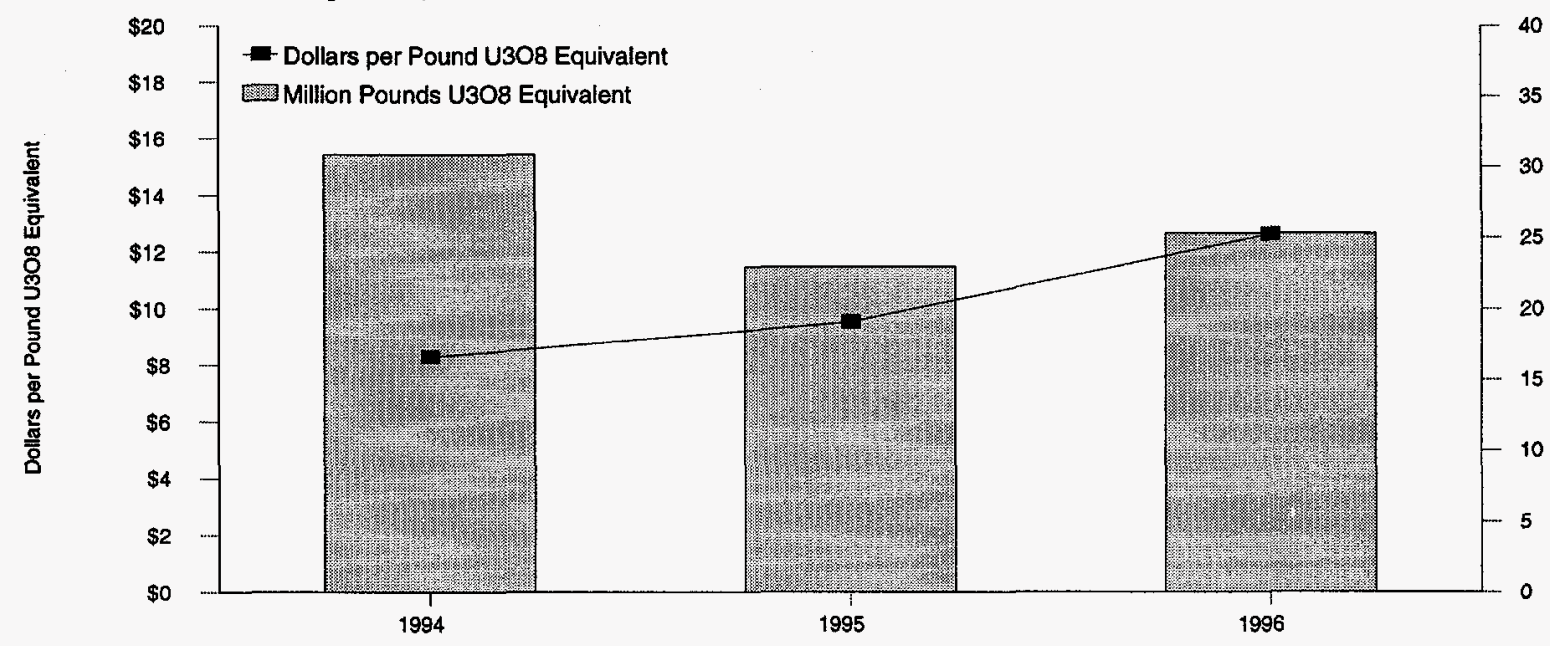

Figure 20. Foreign Sales (Exports) of Uranium by Quantity, Weighted-Average Price, and Delivery Year, 1994-1996

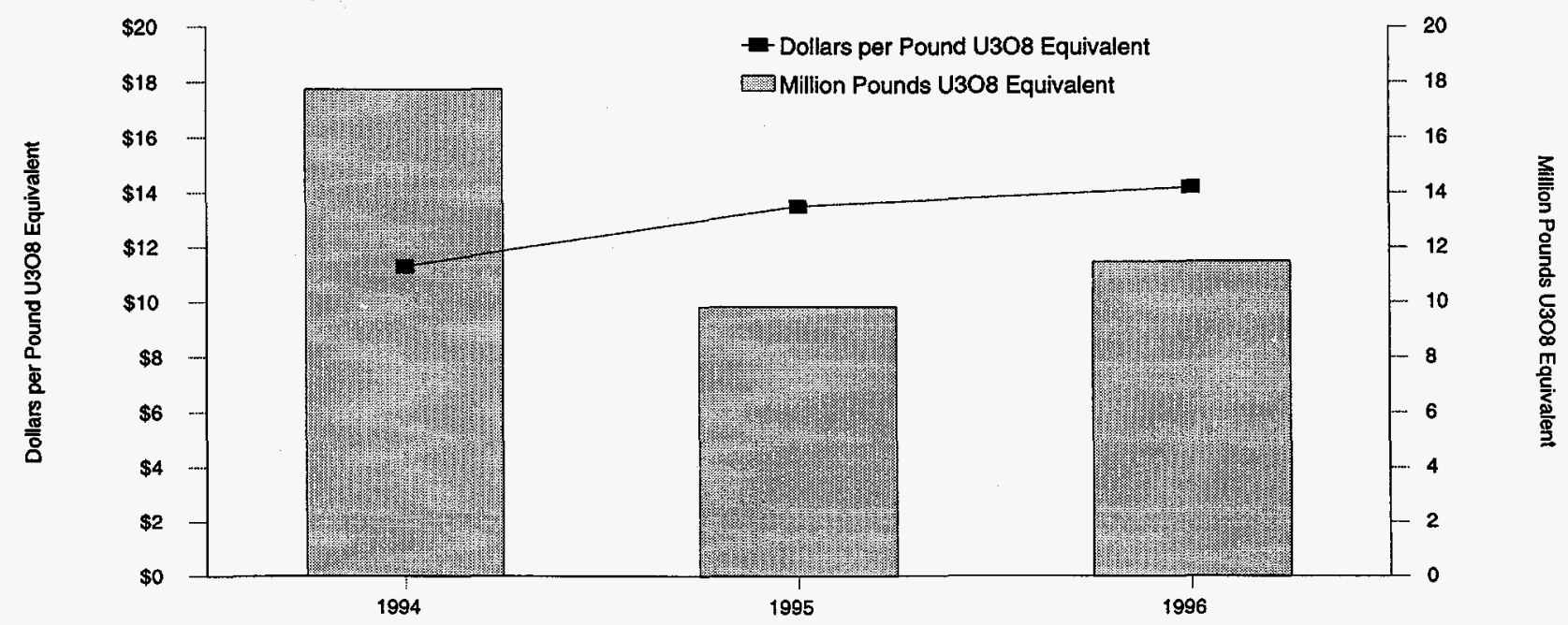

Source: Energy Information Administration, Form EIA-858, "Uranium Industry Annual Survey" (1994-1996). 
Figure 21. Commercial Uranium Inventories at End of the Year, 1994-1996

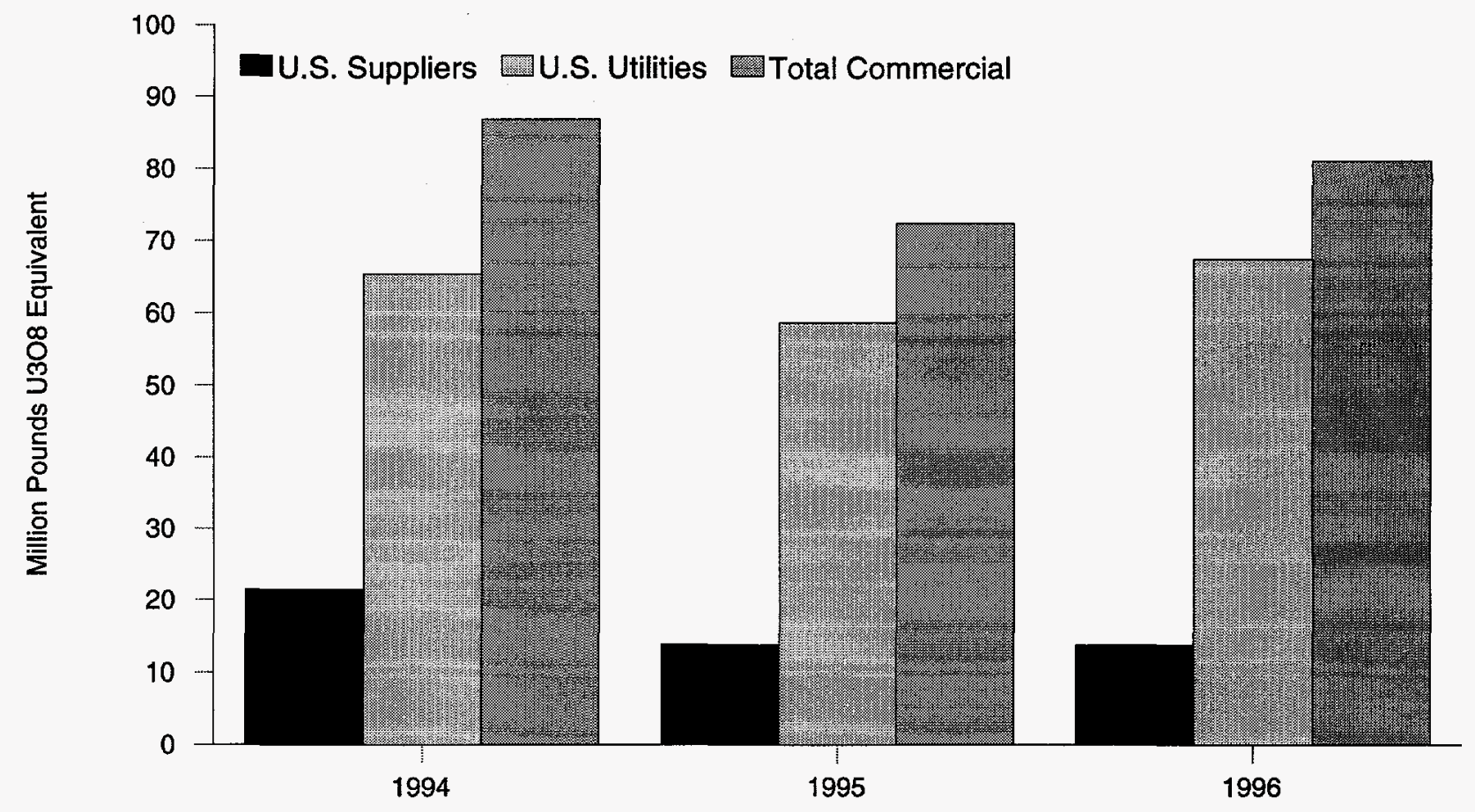

Figure 22. U.S. Utilities Uranium Inventories at End of the Year, 1994-1996

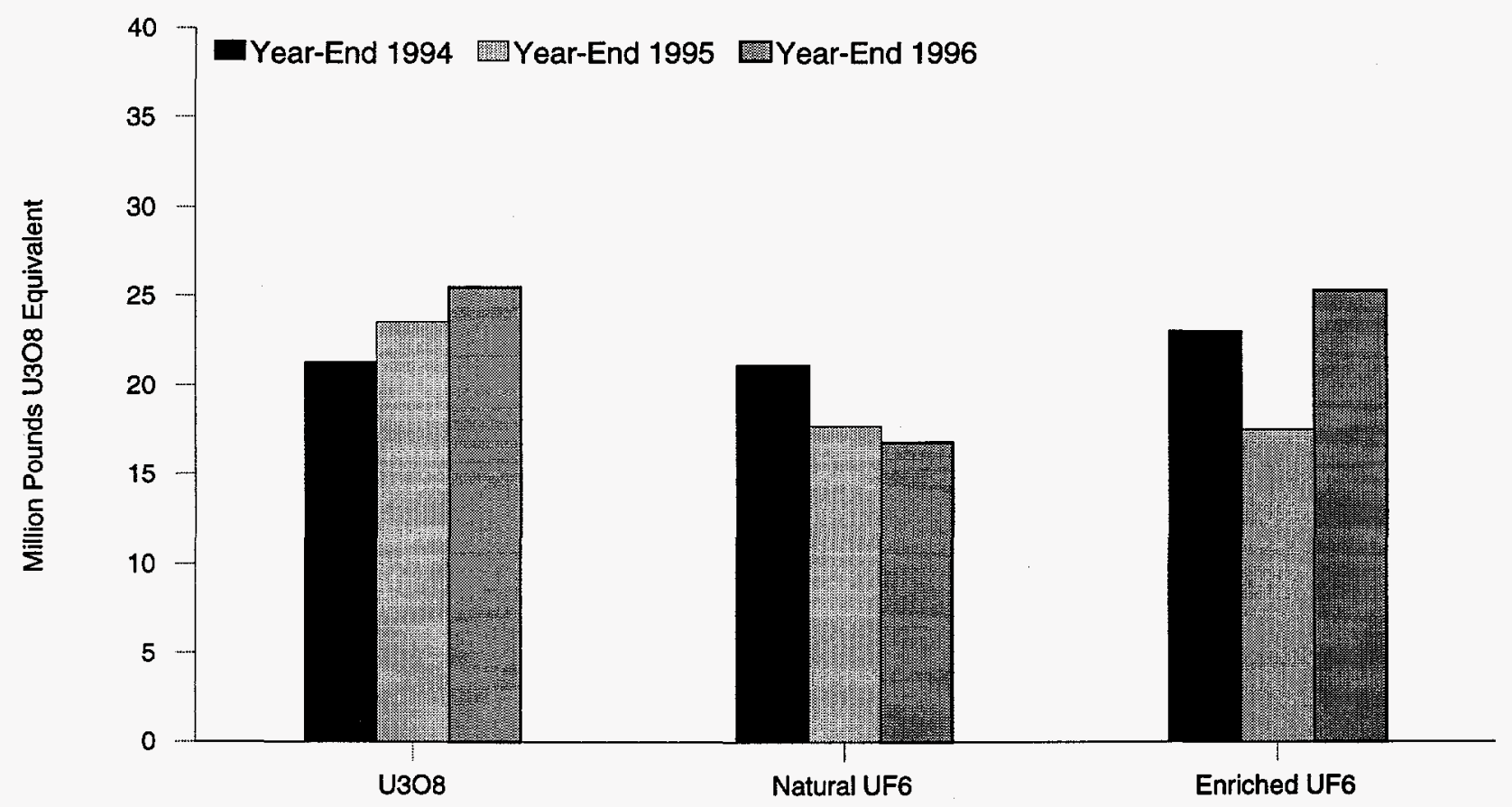

Source: Energy information Administration, Form EIA-858, "Uranium Industry Annual Survey" (1994-1996). 
Table 10. U.S. Utilities Contracted Uranium by Supplier, Transaction Type, and Delivery Year, 1994-1996

(Thousand Pounds $\mathrm{U}_{3} \mathrm{O}_{8}$ Equivalent; Dollars per Pound $\mathrm{U}_{3} \mathrm{O}_{8}$ Equivalent)

\begin{tabular}{|c|c|c|c|}
\hline Actual Deliveries & 1994 & 1995 & 1996 \\
\hline \multicolumn{4}{|l|}{ Received by U.S. Utilities from U.S. Producers: } \\
\hline 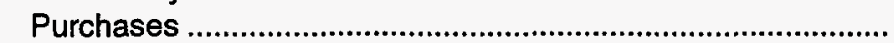 & 5,442 & 5,289 & 5,766 \\
\hline 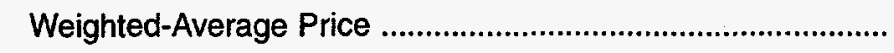 & 13.72 & 14.84 & 14.20 \\
\hline \multicolumn{4}{|l|}{ Received by U.S. Utilities from U.S. Brokers and Traders: } \\
\hline 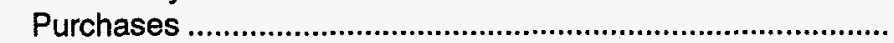 & 15,284 & 16,202 & 13,322 \\
\hline 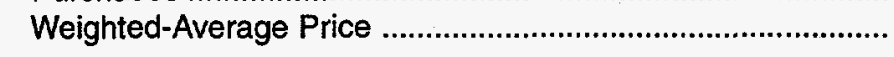 & 9.34 & 9.83 & 13.36 \\
\hline \multicolumn{4}{|l|}{ Received by U.S. Utilities from other U.S. Utilities: } \\
\hline 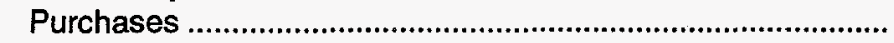 & 0 & 0 & 0 \\
\hline 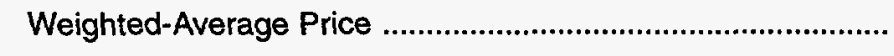 & 一 & 一 & - \\
\hline \multicolumn{4}{|l|}{ Received by U.S. Utilities from other U.S. suppliers: } \\
\hline 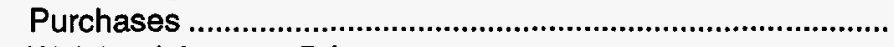 & 1,092 & 561 & a1,885 \\
\hline 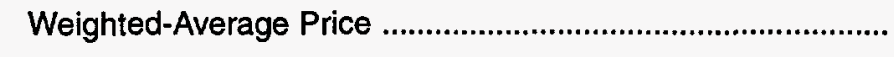 & 8.04 & 12.52 & 14.98 \\
\hline \multicolumn{4}{|l|}{ Received by U.S. Utilities from Foreign Suppliers: } \\
\hline 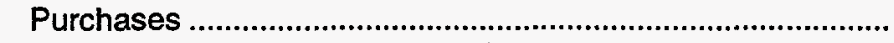 & 16,463 & 21,389 & 26,360 \\
\hline 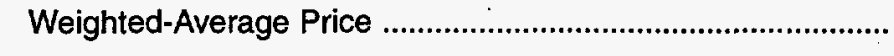 & 10.43 & 11.40 & 14.45 \\
\hline \multicolumn{4}{|l|}{ Total Received by U.S. Utilities: } \\
\hline Purchases & 38,281 & 43,441 & a47,333 \\
\hline 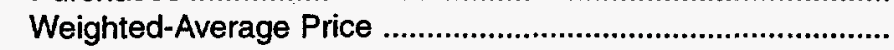 & 10.40 & 11.25 & 14.12 \\
\hline
\end{tabular}

'The quantity with a reported price was 1,131 thousand pounds $\mathrm{U}_{3} \mathrm{O}_{8}$ equivalent from other U.S. suppliers and 46,579 thousand pounds $\mathrm{U}_{3} \mathrm{O}_{8}$ equivalent for total received by U.S. utilities.

$--=$ Not applicable.

Note: "Other U.S. suppliers" are U.S. converters, enrichers, and fabricators.

Source: Energy Information Administration, Form ElA-858, "Uranium Industry Annual Survey" (1994-1996).

Table 11. U.S. Utilities Contracted Uranium by Transaction Type and Delivery Year, 1994-1996 (Thousand Pounds $\mathrm{U}_{3} \mathrm{O}_{8}$ Equivalent; Dollars per Pound $\mathrm{U}_{3} \mathrm{O}_{8}$ Equivalent)

\begin{tabular}{|c|c|c|c|}
\hline Actual Deliveries & 1994 & 1995 & 1996 \\
\hline \multicolumn{4}{|l|}{ Received by U.S. Utilities of U.S.-Origin Uranium: } \\
\hline 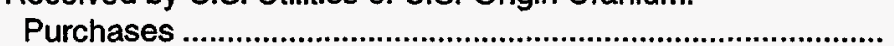 & 7,718 & 5,246 & a8,299 \\
\hline 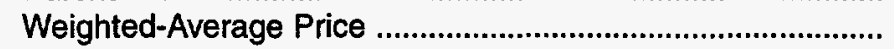 & 12.08 & 14.20 & 14.62 \\
\hline \multicolumn{4}{|l|}{ Received by U.S. Utilities of Foreign-Origin Uranium: } \\
\hline 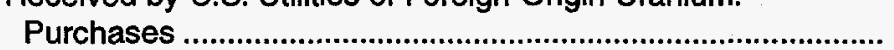 & 30,563 & 38,195 & 39,034 \\
\hline 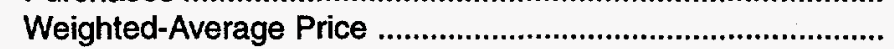 & 9.97 & 10.84 & 14.02 \\
\hline \multicolumn{4}{|l|}{ Total: } \\
\hline (1) & 38,281 & 43,441 & $\mathbf{a 4 7 , 3 3 3}$ \\
\hline 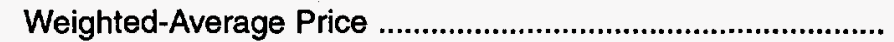 & 10.40 & 11.25 & 14.12 \\
\hline
\end{tabular}

aThe quantity with a reported price was 7,589 thousand pounds $\mathrm{U}_{3} \mathrm{O}_{8}$ equivalent of U.S.-origin uranium, 38,990 thousand pounds $\mathrm{U}_{3} \mathrm{O}_{8}$ equvalent of foreign-origin uranium, and 46,579 thousand pounds $U_{3} O_{8}$ equivalent for total received by $U$.S. utilities.

Source: Energy Information Administration, Form ElA-858, "Uranium Industry Annual Survey" (1994-1996). 
Table 12. U.S. Utilities Purchases of Uranium by Origin Country and Delivery Year, 1994-1996 (Thousand Pounds $\mathrm{U}_{3} \mathrm{O}_{8}$ Equivalent; Dollars per Pound $\mathrm{U}_{3} \mathrm{O}_{8}$ Equivalent)

\begin{tabular}{|c|c|c|c|c|c|c|}
\hline \multirow[b]{2}{*}{ Origin Country } & \multicolumn{2}{|c|}{ Actual Deliveries in 1994} & \multicolumn{2}{|c|}{ Actual Deliveries in 1995} & \multicolumn{2}{|c|}{ Actual Deliveries in 1996} \\
\hline & Purchases & $\begin{array}{c}\text { Weighted- } \\
\text { Average Price }\end{array}$ & Purchases & $\begin{array}{c}\text { Weighted- } \\
\text { Average Price }\end{array}$ & Purchases & $\begin{array}{c}\text { Weighted- } \\
\text { Average Price }\end{array}$ \\
\hline \multicolumn{7}{|l|}{ All Purchases: } \\
\hline 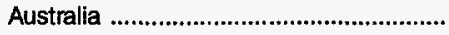 & 2,812 & 9.88 & 4,448 & 10.98 & 4,558 & 14.66 \\
\hline Brazil & w & w & 0 & - & 0 & - \\
\hline 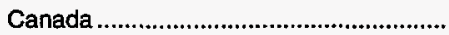 & 14,613 & 10.49 & 16,799 & 11.82 & 19,093 & 14.35 \\
\hline China & 1,696 & 9.56 & 293 & 11.49 & 371 & 15.31 \\
\hline 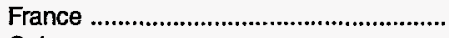 & w & w & w & w & w & w \\
\hline Gabon & w & w & $w$ & w & w & $\mathbf{w}$ \\
\hline 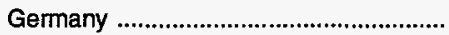 & $w$ & W & W & W & 968 & 13.54 \\
\hline 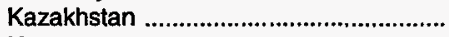 & 2,777 & 8.94 & 3,097 & 8.99 & 1,495 & 14.63 \\
\hline 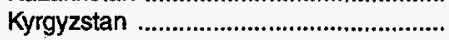 & $w$ & W & $W$ & W & 0 & - \\
\hline Mongolia & w & $w$ & w & w & w & w \\
\hline Namibia & 796 & 9.76 & 530 & 9.88 & w & w \\
\hline Netheriands & 0 & - & $w$ & w & w & $\mathbf{w}$ \\
\hline Nlger & 0 & - & $w$ & w & w & $\mathbf{w}$ \\
\hline Russia & 1,779 & 8.81 & 5,500 & 9.45 & 5,434 & 12.69 \\
\hline 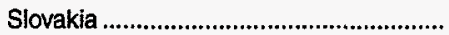 & 0 & - & 0 & - & w & W \\
\hline 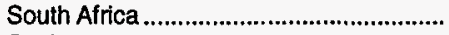 & 1,106 & 9.64 & 1,002 & 12.57 & 1,671 & 13.36 \\
\hline Spain & 0 & - & w & w & 0 & - \\
\hline Tajikistan & w & W & W & w & w & w \\
\hline 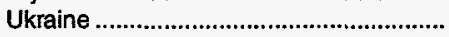 & $w$ & W & w & w & 991 & 13.59 \\
\hline United Kingdom & $w$ & w & $w$ & w & 0 & - \\
\hline Uzbekistan & 3,550 & 8.35 & 3,895 & 8.61 & 3,462 & 13.51 \\
\hline Total Foreign ................................................. & 30,563 & 9.97 & 38,195 & 10.84 & 39,034 & 14.02 \\
\hline 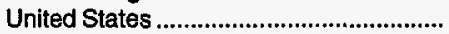 & 7,718 & 12.08 & 5,246 & 14.20 & 8,299 & 14.62 \\
\hline Total Purchases & 38,281 & 10.40 & 43,441 & 11.25 & 47,333 & 14.12 \\
\hline \multicolumn{7}{|l|}{ Domestic Purchases (Non-Imports): } \\
\hline Australia & 1,297 & 9.52 & 2,333 & 10.64 & 807 & 15.47 \\
\hline Canada & 4,622 & 10.06 & 2,326 & 13.19 & 3,335 & 13.49 \\
\hline China & 1,616 & 9.42 & $w$ & w & 371 & 15.31 \\
\hline France & w & w & 0 & - & $\mathbf{w}$ & $\mathbf{w}$ \\
\hline Gabon & W & W & 0 & - & $\mathbf{w}$ & $\mathbf{w}$ \\
\hline Germany & w & w & $w$ & w & $\mathbf{w}$ & w \\
\hline 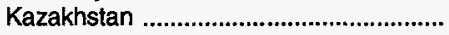 & 976 & 9.15 & 1,760 & 8.30 & 256 & 14.52 \\
\hline Kyrgyzstan & w & w & $\mathbf{w}$ & w & 0 & - \\
\hline 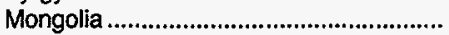 & w & $w$ & W & W & $w$ & w \\
\hline Namibla & 425 & 9.26 & $\mathbf{w}$ & W & $\mathbf{w}$ & w \\
\hline 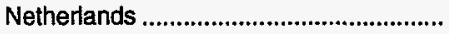 & 0 & - & 0 & - & $\mathbf{w}$ & $\mathbf{w}$ \\
\hline Niger & 0 & - & 0 & - & $\mathbf{w}$ & $\mathbf{w}$ \\
\hline Russia & 762 & 9.24 & 3,776 & 9.47 & 4,350 & 12.81 \\
\hline Slovakia & 0 & - & 0 & - & w & $\mathbf{w}$ \\
\hline 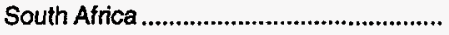 & 1,106 & 9.64 & w & $w$ & 896 & 12.69 \\
\hline Tajikistan & w & $w$ & w & w & 0 & - \\
\hline Ukraine & 0 & - & w & w & 991 & 13.59 \\
\hline United Kingdom & W & w & w & $\mathbf{w}$ & 0 & - \\
\hline 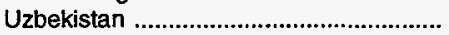 & 3,223 & 7.95 & w & $\mathbf{w}$ & $\mathbf{w}$ & $\mathbf{w}$ \\
\hline 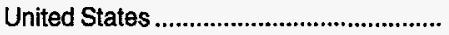 & 7,718 & 12.08 & 5,246 & 14.20 & 8,299 & 14.62 \\
\hline Total Domestic Purchases ........................ & 22,745 & 10.30 & 22,302 & 11.11 & 23,657 & 13.81 \\
\hline \multicolumn{7}{|l|}{ Foreign Purchases (Imports): } \\
\hline Australia & 1,515 & 10.20 & 2,115 & 11.35 & 3,751 & 14.48 \\
\hline Brazil & w & w & 0 & - & 0 & - \\
\hline Canada & 9,991 & 10.69 & 14,473 & 11.60 & 15,758 & 14.52 \\
\hline China & 80 & 12.43 & w & $\mathbf{w}$ & 0 & - \\
\hline France & 0 & - & w & $\mathbf{w}$ & 0 & - \\
\hline Gabon & $w$ & W & w & $\mathbf{w}$ & $\mathbf{w}$ & w \\
\hline Germany & 0 & - & 0 & - & $\mathbf{w}$ & w \\
\hline 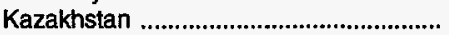 & 1,801 & 8.83 & 1,337 & 9.90 & 1,239 & 14.66 \\
\hline Kyrgyzstan & w & w & 0 & - & 0 & - \\
\hline Namibia & 371 & 10.34 & $\mathbf{w}$ & $\mathbf{w}$ & 0 & - \\
\hline 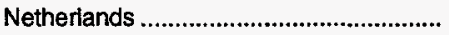 & 0 & - & W & w & 0 & - \\
\hline Niger & 0 & - & w & $\mathbf{w}$ & 0 & - \\
\hline Russia ............................................................ & 1,017 & 8.49 & 1,724 & 9.42 & 1,084 & 12.22 \\
\hline 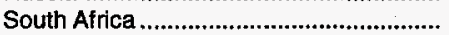 & 0 & - & w & $w$ & 775 & 14.14 \\
\hline Spain & 0 & - & W & w & 0 & - \\
\hline Tajikistan & 0 & - & W & w & $\mathbf{w}$ & $\mathbf{w}$ \\
\hline Ukraine & w & w & 0 & - & 0 & - \\
\hline Uzbekistan & 327 & 12.25 & w & w & $\mathbf{w}$ & $w$ \\
\hline Total Foreign Purchases ........................ & 15,536 & 10.53 & 21,139 & 11.39 & 23,676 & 14.41 \\
\hline
\end{tabular}

$W=$ Data withheld to avoid disclosure. $--=$ Not applicable.

Source: Energy Information Administration, Form EIA-858, "Uranium Industry Annual Survey" (1994-1996). 
Table 13. U.S. Utilities Contracted Uranium by Transaction Type, Material Type, and Delivery Year, 1996

(Thousand Pounds $\mathrm{U}_{3} \mathrm{O}_{8}$ Equivalent; Dollars per Pound $\mathrm{U}_{3} \mathrm{O}_{8}$ Equivalent)

\begin{tabular}{|c|c|c|c|c|}
\hline Actual Deliveries & $\mathrm{U}_{3} \mathrm{O}_{\mathrm{B}}$ & Natural $\mathrm{UF}_{6}$ & $\begin{array}{l}\text { Enriched } \\
\text { Uranium }\end{array}$ & Total \\
\hline \multicolumn{5}{|l|}{ Received by U.S. Utilities of U.S.-Origin Uranium: } \\
\hline 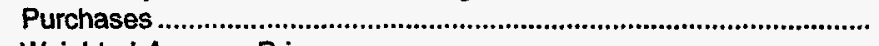 & 6,347 & 828 & 1,124 & 8,299 \\
\hline Weighted-Average Price & 14.20 & 14.50 & 21.21 & 14.62 \\
\hline \multicolumn{5}{|l|}{ Received by U.S. Utilities of Foreign-Origin Uranium: } \\
\hline Purchases & 32,756 & 4,902 & 1,376 & 39,034 \\
\hline 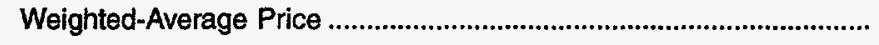 & 14.09 & 13.88 & 12.88 & 14.02 \\
\hline \multicolumn{5}{|l|}{ Total: } \\
\hline 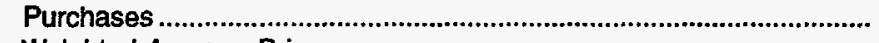 & 39,103 & 5,730 & 2,500 & 47,333 \\
\hline 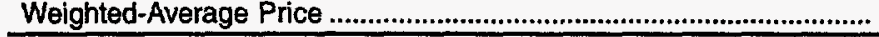 & 14.11 & 13.97 & 14.86 & 14.12 \\
\hline
\end{tabular}

$--=$ Not applicable.

Source: Energy Information Administration, Form EIA-858, "Uranium Industry Annual Survey" (1996).

Table 14. Average Price and Quantity for Purchases of Uranium by U.S. Utilities by Pricing Mechanisms and Delivery Year, 1994-1996

(Dollars per Pound $\mathrm{U}_{3} \mathrm{O}_{8}$ Equivalent; Thousand Pounds $\mathrm{U}_{3} \mathrm{O}_{8}$ Equivalent)

\begin{tabular}{|c|c|c|c|c|c|c|c|c|c|}
\hline \multirow[b]{2}{*}{ Pricing Mechanisms } & \multicolumn{3}{|c|}{ Domestic Purchases" } & \multicolumn{3}{|c|}{ Foreign Purchasesb } & \multicolumn{3}{|c|}{ Total Purchases } \\
\hline & 1994 & 1995 & 1996 & 1994 & 1995 & 1996 & 1994 & 1995 & 1996 \\
\hline 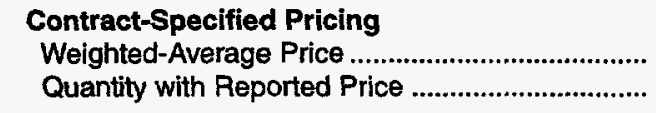 & $\begin{array}{r}10.68 \\
11,154\end{array}$ & $\begin{array}{r}10.58 \\
17,065\end{array}$ & $\begin{array}{r}13.40 \\
16,657\end{array}$ & $\begin{array}{l}11.92 \\
2,489\end{array}$ & $\begin{array}{l}12.96 \\
5,584\end{array}$ & $\begin{array}{l}13.98 \\
5,988\end{array}$ & $\begin{array}{r}10.90 \\
13,643\end{array}$ & $\begin{array}{r}11.16 \\
22,649\end{array}$ & $\begin{array}{r}13.55 \\
22,645\end{array}$ \\
\hline 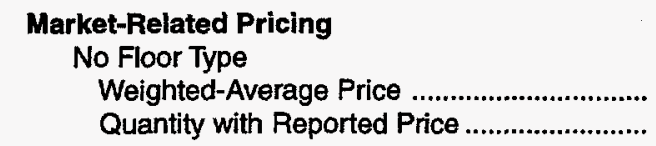 & $\begin{array}{r}9.76 \\
7,083\end{array}$ & $\begin{array}{l}10.19 \\
2,119\end{array}$ & $\begin{array}{l}13.66 \\
2,208\end{array}$ & $\begin{array}{r}9.21 \\
8,269\end{array}$ & $\begin{array}{l}10.85 \\
8,278\end{array}$ & $\begin{array}{l}14.75 \\
5,669\end{array}$ & $\begin{array}{r}9.46 \\
15,352\end{array}$ & $\begin{array}{r}10.72 \\
10,397\end{array}$ & $\begin{array}{l}14.45 \\
7,877\end{array}$ \\
\hline 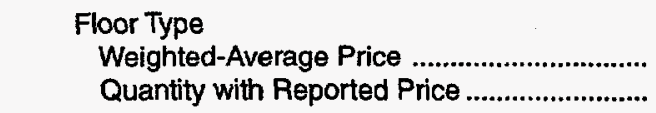 & $\begin{array}{r}20.03 \\
606\end{array}$ & $\begin{array}{r}17.86 \\
683\end{array}$ & $\begin{array}{l}16.13 \\
2,249\end{array}$ & $\begin{array}{l}11.80 \\
3,899\end{array}$ & & $\begin{array}{l}14.64 \\
9,766\end{array}$ & $\begin{array}{l}12.91 \\
4,505\end{array}$ & $\begin{array}{l}11.81 \\
4,974\end{array}$ & $\begin{array}{r}14.92 \\
12,015\end{array}$ \\
\hline 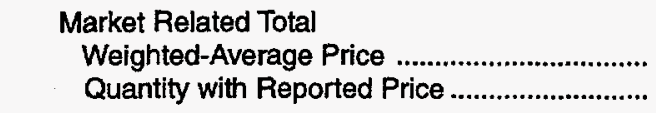 & $\begin{array}{l}10.57 \\
7,689\end{array}$ & $\begin{array}{l}12.05 \\
2,802\end{array}$ & $\begin{array}{l}14.91 \\
4,457\end{array}$ & $\begin{array}{r}10.04 \\
12,168\end{array}$ & $\begin{array}{r}10.85 \\
12,569\end{array}$ & $\begin{array}{r}14.68 \\
15,435\end{array}$ & $\begin{array}{r}10.24 \\
19,857\end{array}$ & $\begin{array}{r}11.07 \\
15,371\end{array}$ & $\begin{array}{r}14.73 \\
19,892\end{array}$ \\
\hline 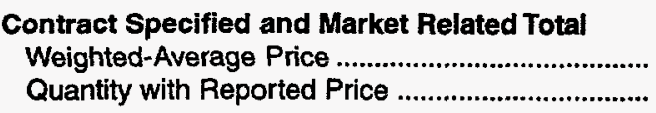 & $\begin{array}{r}10.63 \\
18,843\end{array}$ & $\begin{array}{r}10.79 \\
19,867\end{array}$ & $\begin{array}{r}13.72 \\
21,114\end{array}$ & $\begin{array}{r}10.36 \\
14,657\end{array}$ & $\begin{array}{r}11.50 \\
18,153\end{array}$ & $\begin{array}{r}14.48 \\
21,423\end{array}$ & $\begin{array}{r}10.51 \\
33,500\end{array}$ & $\begin{array}{r}11.13 \\
38,020\end{array}$ & $\begin{array}{r}14.10 \\
42,537\end{array}$ \\
\hline 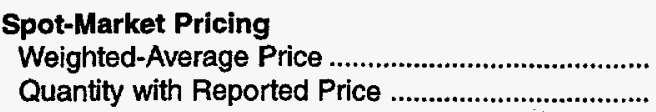 & $\begin{array}{r}9.37 \\
714\end{array}$ & $\begin{array}{r}9.07 \\
748\end{array}$ & $\begin{array}{l}14.90 \\
1,689\end{array}$ & $\overline{0}$ & $\begin{array}{l}10.26 \\
1,706\end{array}$ & $\begin{array}{l}14.26 \\
1,428\end{array}$ & $\begin{array}{r}9.37 \\
714\end{array}$ & $\begin{array}{r}9.90 \\
2,454\end{array}$ & $\begin{array}{l}14.61 \\
3,117\end{array}$ \\
\hline 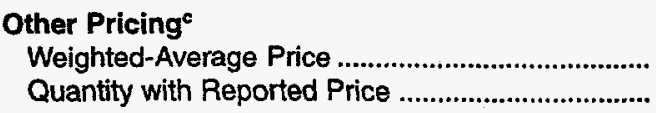 & $\begin{array}{r}8.56 \\
3,188\end{array}$ & $\begin{array}{l}15.87 \\
1,687\end{array}$ & $\begin{array}{r}15.88 \\
100\end{array}$ & $\begin{array}{r}13.43 \\
879\end{array}$ & $\begin{array}{l}11.34 \\
1,280\end{array}$ & $\begin{array}{r}12.89 \\
825\end{array}$ & $\begin{array}{r}9.61 \\
4,067\end{array}$ & $\begin{array}{l}13.92 \\
2,967\end{array}$ & $\begin{array}{r}13.22 \\
925\end{array}$ \\
\hline $\begin{array}{l}\text { All Pricing Mechanisms } \\
\text { Weighted-Average Price .......... } \\
\text { Quantity with Reported Price. }\end{array}$ & $\begin{array}{r}10.30 \\
22,745\end{array}$ & $\begin{array}{r}11.11 \\
22,302\end{array}$ & $\begin{array}{r}13.81 \\
22,903\end{array}$ & $\begin{array}{r}10.53 \\
15,536\end{array}$ & $\begin{array}{r}11.39 \\
21,139\end{array}$ & $\begin{array}{r}14.41 \\
23,676\end{array}$ & $\begin{array}{r}10.40 \\
38,281\end{array}$ & $\begin{array}{r}11.25 \\
43,441\end{array}$ & $\begin{array}{r}14.12 \\
46,579\end{array}$ \\
\hline
\end{tabular}

Uranium of both U.S. and foreign origin.

Uranium of foreign origin only.

cCategory used to report pricing mechanisms that are different from the other categories.

--Not applicable

Source: Energy Information Administration, Form ElA-858, "Uranium Industry Annual Survey" (1994-1996). 
Table 15. Price Distributions of Uranium Purchases by U.S. Utilities by Delivery Year, 1994-1996 (Thousand Pounds $\mathrm{U}_{3} \mathrm{O}_{8}$ Equivalent; Dollars per Pound $\mathrm{U}_{3} \mathrm{O}_{8}$ Equivalent)

\begin{tabular}{|c|c|c|c|c|c|c|}
\hline \multirow[b]{2}{*}{ Distributions } & \multicolumn{2}{|c|}{ Actual Deliveries in 1994} & \multicolumn{2}{|c|}{ Actual Deliveries in 1995} & \multicolumn{2}{|c|}{ Actual Deliveries in 1996} \\
\hline & $\begin{array}{c}\text { Quantity with } \\
\text { Reported Price }\end{array}$ & $\begin{array}{c}\text { Weighted- } \\
\text { Average Price }\end{array}$ & $\begin{array}{c}\text { Quantity with } \\
\text { Reported Price }\end{array}$ & $\begin{array}{c}\text { Weighted- } \\
\text { Average Price }\end{array}$ & $\begin{array}{c}\text { Quantity with } \\
\text { Reported Price }\end{array}$ & $\begin{array}{c}\text { Weighted- } \\
\text { Average Price }\end{array}$ \\
\hline \multicolumn{7}{|l|}{ Octile": } \\
\hline 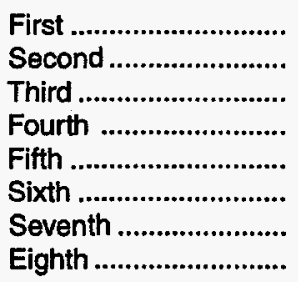 & $\begin{array}{l}4,785 \\
4,785 \\
4,785 \\
4,785 \\
4,785 \\
4,785 \\
4,785 \\
4,785\end{array}$ & $\begin{array}{r}7.08 \\
8.86 \\
9.13 \\
9.23 \\
9.35 \\
9.54 \\
10.89 \\
19.08\end{array}$ & $\begin{array}{l}5,430 \\
5,430 \\
5,430 \\
5,430 \\
5,430 \\
5,430 \\
5,430 \\
5,430\end{array}$ & $\begin{array}{r}7.50 \\
9.34 \\
9.85 \\
10.40 \\
11.06 \\
11.61 \\
12.17 \\
18.05\end{array}$ & $\begin{array}{l}5,822 \\
5,822 \\
5,822 \\
5,822 \\
5,822 \\
5,822 \\
5,822 \\
5,822\end{array}$ & $\begin{array}{l}10.72 \\
11.93 \\
12.62 \\
13.70 \\
14.65 \\
15.23 \\
15.76 \\
18.34\end{array}$ \\
\hline \multicolumn{3}{|l|}{ Quartileb: } & 43,441 & 11.25 & 46,579 & 14.12 \\
\hline 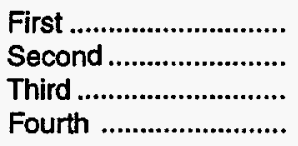 & $\begin{array}{r}11,966 \\
9,878 \\
7,828 \\
8,609\end{array}$ & $\begin{array}{r}8.51 \\
9.35 \\
10.29 \\
14.31\end{array}$ & $\begin{array}{r}15,601 \\
13,620 \\
5,037 \\
9,183\end{array}$ & $\begin{array}{r}9.48 \\
10.74 \\
11.69 \\
14.75\end{array}$ & $\begin{array}{r}12,352 \\
18,626 \\
10,926 \\
4,675\end{array}$ & $\begin{array}{l}12.61 \\
13.92 \\
14.73 \\
17.50\end{array}$ \\
\hline Total Quantity ............ & 38,281 & 10.40 & 43,441 & 11.25 & 46,579 & 14.12 \\
\hline
\end{tabular}

- Octile distribution divides total pounds of uranium delivered (with a price) into eight distributions by price and provides the quantity-weighted average price for each distribution.

QQuartile distribution divides total pounds of uranium delivered (with a price) into four distributions by each utility's aggregate weighted-average price and provides the quantity and average price for each distribution.

Note: Totals may not equal sum of components because of independent rounding.

Sources: Energy Information Administration: 1994-1995-Uranium Industry Annual 1995 (May 1996); 1996-Form ElA-858, "Uranium Industry Annual Survey" (1996).

Table 16. U.S. Utility Uranium Purchases by Contract Type and Material Type, 1996 Deliveries (Thousand Pounds $\mathrm{U}_{3} \mathrm{O}_{8}$ Equivalent; Dollars per Pound $\mathrm{U}_{3} \mathrm{O}_{8}$ Equivalent)

\begin{tabular}{|c|c|c|c|c|c|c|c|c|c|c|}
\hline \multirow[b]{2}{*}{ Material Type } & \multicolumn{2}{|c|}{ Spot Contracts } & \multicolumn{2}{|c|}{$\begin{array}{c}\text { Short-term } \\
\text { Contracts }\end{array}$} & \multicolumn{2}{|c|}{$\begin{array}{l}\text { Medium-term } \\
\text { Contracts }\end{array}$} & \multicolumn{2}{|c|}{$\begin{array}{l}\text { Long-term } \\
\text { Contracts }\end{array}$} & \multicolumn{2}{|c|}{ Total } \\
\hline & \begin{tabular}{|c} 
Quantity \\
with \\
Reported \\
Price
\end{tabular} & $\begin{array}{c}\text { Weighted } \\
\text { Average } \\
\text { Price }\end{array}$ & $\begin{array}{c}\text { Quantity } \\
\text { with } \\
\text { Reported } \\
\text { Price }\end{array}$ & $\begin{array}{c}\text { Weighted } \\
\text { Average } \\
\text { Price }\end{array}$ & $\begin{array}{c}\text { Quantity } \\
\text { with } \\
\text { Reported } \\
\text { Price }\end{array}$ & $\begin{array}{l}\text { Weighted } \\
\text { Average } \\
\text { Price }\end{array}$ & $\begin{array}{c}\text { Quantity } \\
\text { with } \\
\text { Reported } \\
\text { Price }\end{array}$ & $\begin{array}{c}\text { Weighted } \\
\text { Average } \\
\text { Price }\end{array}$ & $\begin{array}{c}\text { Quantity } \\
\text { with } \\
\text { Reported } \\
\text { Price }\end{array}$ & $\begin{array}{l}\text { Weighted } \\
\text { Average } \\
\text { Price }\end{array}$ \\
\hline 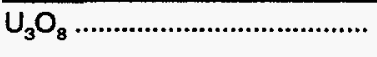 & 6,530 & 13.88 & 2,093 & 13.80 & 15,002 & 13.61 & 15,478 & 14.73 & 39,103 & 14.11 \\
\hline Natural UF ${ }_{6}$ & 1,634 & 15.85 & 262 & 11.68 & 1,255 & 12.58 & 2,579 & 13.69 & 5,730 & 13.97 \\
\hline 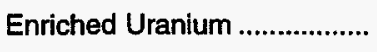 & 919 & 13.70 & 0 & - & 515 & 11.29 & 312 & 24.15 & 1,746 & 14.86 \\
\hline 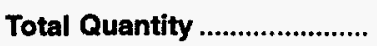 & 9,083 & 14.22 & 2,355 & 13.56 & 16,772 & 13.46 & 18,369 & 14.74 & 46,579 & 14.12 \\
\hline
\end{tabular}

$--=$ Not applicable.

Source: Energy Iniormation Administration, Form EIA-858, "Uranium Industry Annual Survey" (1996). 
Table 17. Contracts Signed by U.S. Utilities in 1996 by Contract Type and Delivery Year 1996 (Thousand Pounds $\mathrm{U}_{3} \mathrm{O}_{8}$ Equivalent; Dollars per Pound $\mathrm{U}_{3} \mathrm{O}_{8}$ Equivalent)

\begin{tabular}{|c|c|c|c|}
\hline Purchase Contract Type & $\begin{array}{c}\text { Quantity of Actual Deliveries } \\
\text { Received in } 1996\end{array}$ & $\begin{array}{l}\text { Weighted- } \\
\text { Average Price }\end{array}$ & $\begin{array}{l}\text { Number of Purchase } \\
\text { Contracts }\end{array}$ \\
\hline 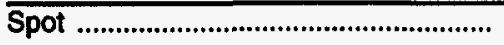 & 6,858 & 14.68 & 39 \\
\hline Short-term & $w$ & W & 2 \\
\hline 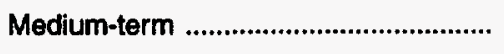 & $w$ & 13.10 & 6 \\
\hline 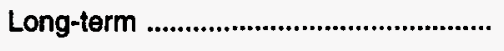 & 2,477 & 14.95 & 5 \\
\hline 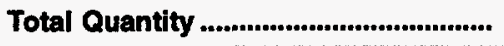 & 12,634 & 14.35 & 52 \\
\hline
\end{tabular}

$W=$ Data withheld to avoid disclosure.

Source: Energy Information Administration, Form ElA-858, "Uranium Industry Annual Survey" (1996).

Table 18. U.S. Utilities Contracted Purchases of Uranium, Signed in 1996, by Delivery Year, 1997-2006

(Thousand Pounds $\mathrm{U}_{3} \mathrm{O}_{8}$ Equivalent)

\begin{tabular}{|c|c|c|c|}
\hline Year of Delivery & Firm Deliveries & Optional Deliveries & Total Deliveries \\
\hline $1997 \ldots . .$. & 8,052 & 509 & 8,561 \\
\hline 1998 & 10,393 & 654 & 11,047 \\
\hline 1999 & 9,496 & 832 & 10,328 \\
\hline 2000 & 9,577 & 1,203 & 10,780 \\
\hline 2001 & 5,347 & 1,246 & 6,593 \\
\hline 2002 & 3,893 & 415 & 4,308 \\
\hline 2003 & 2,005 & 370 & 2,375 \\
\hline 2004 & 1,090 & 705 & 1,795 \\
\hline 2005 & 490 & 1,089 & 1,579 \\
\hline 2006 & 0 & 0 & 0 \\
\hline |........................................ & 50,343 & 7,023 & 57,366 \\
\hline
\end{tabular}

Source: Energy Information Administration, Form ElA-858, "Uranium Industry Annual Survey" (1996). 
Table 19. U.S. Utilities Contracted Purchases of Uranium from Suppliers, in Effect at the End of 1996, by Delivery Year, 1997-2006

(Thousand Pounds $\mathrm{U}_{3} \mathrm{O}_{8}$ Equivalent)

\begin{tabular}{|c|c|c|c|c|c|c|}
\hline \multirow[b]{2}{*}{ Year of Delivery } & \multicolumn{2}{|c|}{$\begin{array}{c}\text { Purchases from U.S. } \\
\text { Suppliers }\end{array}$} & \multicolumn{2}{|c|}{$\begin{array}{c}\text { Purchases from Foreign } \\
\text { Suppliers }\end{array}$} & \multicolumn{2}{|c|}{$\begin{array}{l}\text { Purchases from All } \\
\text { Suppliers }\end{array}$} \\
\hline & $\begin{array}{c}\text { Firm } \\
\text { Deliveries }\end{array}$ & $\begin{array}{l}\text { Optional } \\
\text { Deliveries }\end{array}$ & $\begin{array}{c}\text { Firm } \\
\text { Deliveries }\end{array}$ & $\begin{array}{l}\text { Optional } \\
\text { Deliveries }\end{array}$ & $\begin{array}{c}\text { Firm } \\
\text { Deliveries }\end{array}$ & $\begin{array}{l}\text { Optional } \\
\text { Deliveries }\end{array}$ \\
\hline $1997 .$. & 14,951 & 839 & 20,940 & 3,298 & 35,891 & 4,137 \\
\hline 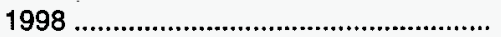 & 12,968 & 1,876 & 19,254 & 4,404 & 32,222 & 6,280 \\
\hline 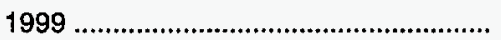 & 10,026 & 1,603 & 14,556 & 3,943 & 24,582 & 5,546 \\
\hline 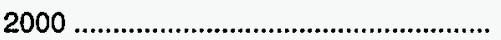 & 9,330 & 2,894 & 14,513 & 2,188 & 23,843 & 5,082 \\
\hline 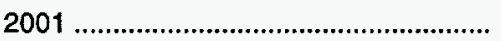 & 5,987 & 916 & 7,659 & 2,712 & 13,646 & 3,628 \\
\hline 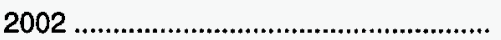 & 4,162 & 1,788 & 5,493 & 2,328 & $\$, 655$ & 4,116 \\
\hline 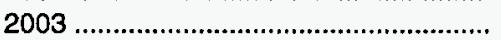 & 1,562 & 1,102 & 2,050 & 2,170 & 3,612 & 3,272 \\
\hline 2004 & 1,467 & 1,825 & 971 & 2,050 & 2,438 & 3,876 \\
\hline 2005 & 495 & 852 & 265 & 2,534 & 760 & 3,386 \\
\hline 2006 & 0 & 752 & 0 & 800 & 0 & 1,552 \\
\hline 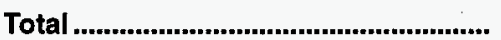 & 60,948 & 14,448 & 85,701 & 26,427 & 146,649 & 40,875 \\
\hline
\end{tabular}

Source: Energy Information Administration, Form ElA-858, "Uranium Industry Annual Survey" (1996).

Table 20. Unfilled Uranium Requirements of U.S. Utilities, 1997-2006

(Thousand Pounds $\mathrm{U}_{3} \mathrm{O}_{8}$ Equivalent)

\begin{tabular}{|c|c|c|c|c|}
\hline \multirow[b]{2}{*}{ Year } & \multicolumn{2}{|c|}{ As of December 31, 1995} & \multicolumn{2}{|c|}{ As of December 31, 1996} \\
\hline & Annual & Cumulative & Annual & Cumulative \\
\hline $\begin{array}{l}1997 \\
1998 \\
1999 \\
2000 \\
2001\end{array}$ & $\begin{array}{r}8,285 \\
15,709 \\
23,200 \\
34,497 \\
42,600 \\
43,184 \\
48,955 \\
48,715 \\
43,759 \\
\text { NR }\end{array}$ & $\begin{array}{r}8,285 \\
23,994 \\
47,194 \\
81,691 \\
124,291 \\
167,475 \\
216,430 \\
265,145 \\
308,904 \\
-\end{array}$ & $\begin{array}{r}1,545 \\
8,388 \\
13,740 \\
20,480 \\
30,339 \\
37,381 \\
45,564 \\
50,321 \\
47,970 \\
50,449\end{array}$ & $\begin{array}{r}1,545 \\
9,933 \\
23,673 \\
44,153 \\
74,492 \\
111,873 \\
157,437 \\
207,758 \\
255,728 \\
306,177\end{array}$ \\
\hline
\end{tabular}

NR=Not Reported. --=Not applicable.

Source: Energy Information Administration, Form ElA-858, "Uranium Industry Annual Survey" (1995-1996). 
Table 21. Anticipated Uranium Market Requirements of U.S. Utilities, 1997-2006, as of December 31, 1996

(Thousand Pounds $\mathrm{U}_{3} \mathrm{O}_{8}$ Equivalent)

\begin{tabular}{|c|c|c|c|c|}
\hline Year & $\begin{array}{l}\text { Quantity of Uranium Under } \\
\text { Purchase Contracts }\end{array}$ & Unfilled Requirements & $\begin{array}{l}\text { Anticipated Market } \\
\text { Requirements }\end{array}$ & Enrichment Feed Deliveries \\
\hline 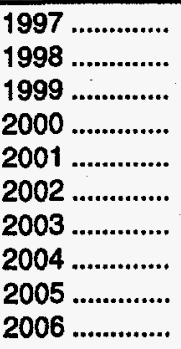 & \begin{tabular}{r|}
40,028 \\
38,502 \\
30,128 \\
28,925 \\
17,274 \\
13,771 \\
6,884 \\
6,314 \\
4,146 \\
1,552
\end{tabular} & \begin{tabular}{r|}
1,545 \\
8,388 \\
13,740 \\
20,480 \\
30,339 \\
37,381 \\
45,564 \\
50,321 \\
47,970 \\
50,449
\end{tabular} & $\begin{array}{l}41,573 \\
46,890 \\
43,868 \\
49,405 \\
47,613 \\
51,152 \\
52,448 \\
56,635 \\
52,116 \\
52,001\end{array}$ & $\begin{array}{l}41,279 \\
49,724 \\
42,438 \\
50,132 \\
39,980 \\
39,425 \\
35,469 \\
38,481 \\
32,601 \\
34,424\end{array}$ \\
\hline Total ............... & 187,524 & 306,177 & 493,701 & 403,953 \\
\hline
\end{tabular}

Source: Energy Information Administration, Form EIA-858, "Uranium Industry Annual Survey" (1996).

Table 22. U.S. Utilities Deliveries of Uranium Feed by Enrichment Country and Delivery Year, 1994-1996

(Thousand Pounds $\mathrm{U}_{3} \mathrm{O}_{8}$ Equivalent)

\begin{tabular}{|c|c|c|c|c|c|c|c|c|c|}
\hline \multirow[b]{2}{*}{$\begin{array}{l}\text { Enrichment Plant } \\
\text { Location }\end{array}$} & \multicolumn{3}{|c|}{ Actual Deliveries in 1994} & \multicolumn{3}{|c|}{ Actual Deliveries in 1995} & \multicolumn{3}{|c|}{ Actual Deliveries in 1996} \\
\hline & $\begin{array}{l}\text { U.S.- } \\
\text { Origin }\end{array}$ & $\begin{array}{l}\text { Foreign- } \\
\text { Origin }\end{array}$ & Total & $\begin{array}{l}\text { U.S.- } \\
\text { Origin }\end{array}$ & $\begin{array}{c}\text { Foreign- } \\
\text { Origin }\end{array}$ & Total & $\begin{array}{l}\text { U.S.- } \\
\text { Origin }\end{array}$ & $\begin{array}{c}\text { Foreign- } \\
\text { Origin }\end{array}$ & Total \\
\hline 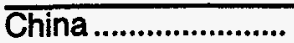 & $\bar{W}$ & $\bar{W}$ & $\bar{W}$ & $\overline{0}$ & $\overline{0}$ & 0 & 0 & $\overline{0}$ & $\overline{0}$ \\
\hline France.. & w & w & 1,111 & $w$ & w & 302 & 378 & 026 & 404 \\
\hline Germany & 0 & 0 & 0 & w & w & 870 & w & w & w \\
\hline Netherlands ............ & 0 & 1,012 & 1,012 & W & w & 951 & W & w & w \\
\hline (................. & w & w & 1,345 & 837 & 1,874 & 2,711 & 248 & 1,543 & 1,791 \\
\hline South Africa ............. & 0 & 0 & 0 & 0 & 0 & 0 & 0 & 0 & 0 \\
\hline United Kingdom ...... & 0 & $W$ & W & 0 & 1,059 & 1,059 & W & w & 598 \\
\hline Foreign Total ........... & 51 & 4,059 & 4,110 & 1,390 & 9,003 & 10,393 & 700 & $\mathbf{9 , 7 2 8}$ & 10,428 \\
\hline United States ........... & 8,471 & 25,027 & 33,498 & 7,786 & 26,115 & 33,901 & 8,306 & 30,345 & 38,651 \\
\hline Total .......................... & 8,522 & 29,086 & 37,608 & 9,176 & 35,118 & 44,294 & 9,006 & 40,073 & 49,079 \\
\hline
\end{tabular}

$W=$ Data withheld to avoid disclosure.

Source: Energy Information Administration, Form ElA-858, "Uranium Industry Annual Survey" (1994-1996). 
Table 23. U.S. Utilities Deliveries of Uranium Feed for Enrichment by Origin Country and Delivery Year, 1994-1996

(Thousand Pounds $\mathrm{U}_{3} \mathrm{O}_{8}$ Equivalent)

\begin{tabular}{|c|c|c|c|c|c|c|c|c|c|}
\hline \multirow[b]{2}{*}{$\begin{array}{l}\text { Origin Country } \\
\text { of Feed }\end{array}$} & \multicolumn{3}{|c|}{ Actual Deliveries in 1994} & \multicolumn{3}{|c|}{ Actual Deliveries in 1995} & \multicolumn{3}{|c|}{ Actual Deliveries in 1996} \\
\hline & $\begin{array}{c}\text { To U.S. } \\
\text { Enrichers }\end{array}$ & $\begin{array}{l}\text { To Foreign } \\
\text { Enrichers }\end{array}$ & Total & $\begin{array}{c}\text { To U.S. } \\
\text { Enrichers }\end{array}$ & $\begin{array}{l}\text { To Foreign } \\
\text { Enrichers }\end{array}$ & Total & $\begin{array}{c}\text { To U.S. } \\
\text { Enrichers }\end{array}$ & $\begin{array}{l}\text { To Foreign } \\
\text { Enrichers }\end{array}$ & Total \\
\hline 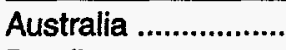 & 2,880 & 0 & 2,880 & 2,890 & 410 & 3,300 & 5,058 & 723 & 5,781 \\
\hline 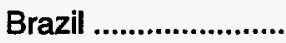 & w & 0 & w & w & 0 & w & 0 & 0 & 0 \\
\hline Canada ..................... & 13,870 & 998 & 14,868 & 15,533 & 2,186 & 17,719 & 17,469 & 2,959 & 20,428 \\
\hline 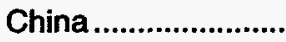 & W & W & 1,429 & W & 0 & w & W & W & 120 \\
\hline France ......................... & W & 0 & w & w & 0 & W & 0 & 0 & 0 \\
\hline 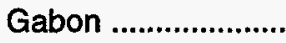 & W & 0 & w & w & w & 218 & W & W & 21 \\
\hline Germany ................... & w & 0 & w & 365 & 0 & 365 & w & W & 801 \\
\hline Kazakhstan .............. & 2,041 & 1,429 & 3,470 & w & w & 2,469 & 1,531 & 563 & 2,094 \\
\hline Kyrgyzstan .............. & 0 & W & W & 0 & W & w & 0 & 0 & 0 \\
\hline Mongolia .................. & w & 0 & w & w & 0 & w & w & 0 & w \\
\hline Namibia ..................... & 804 & 0 & 804 & 738 & 0 & 738 & w & w & 282 \\
\hline Niger ........ & 0 & 0 & 0 & 0 & 0 & 0 & 0 & $\mathbf{w}$ & w \\
\hline Russia ........................... & 992 & 772 & 1,764 & 1,936 & 5,072 & 7,008 & 1,952 & 1,333 & 3,285 \\
\hline South Africa ............. & w & w & 1,195 & w & w & 709 & 1,364 & 644 & 2,008 \\
\hline Spain & W & 0 & W & W & 0 & w & 0 & 0 & 0 \\
\hline Tajikistan ....................... & 0 & 0 & 0 & 805 & 0 & 805 & w & 0 & w \\
\hline Ukraine... & 0 & W & w & W & W & 401 & 0 & W & w \\
\hline United Kingdom ...... & w & 0 & w & w & 0 & w & w & 0 & w \\
\hline Uzbekistan ................ & 340 & 375 & 715 & w & W & 514 & 1,587 & 2,273 & 3,860 \\
\hline Foreign Total .......... & 25,027 & 4,059 & 29,086 & 26,115 & 9,003 & 35,118 & 30,345 & 9,728 & 40,073 \\
\hline United States .......... & 8,471 & 51 & 8,522 & 7,786 & 1,390 & 9,176 & 8,306 & 700 & 9,006 \\
\hline Total ......................... & 98 & 4,110 & 37,608 & 33,901 & 10,393 & 44,294 & 38,651 & 10,428 & 49,079 \\
\hline
\end{tabular}

$W=$ Data withheld to avoid disclosure.

Source: Energy Information Administration, Form EIA-858, "Uranium Industry Annual Survey" (1994-1996).

Table 24. Shipments of Uranium by U.S. Utilities to Domestic and Foreign Enrichment Suppliers, 1997-2006

(Thousand Pounds $\mathrm{U}_{3} \mathrm{O}_{8}$ Equivalent)

\begin{tabular}{|c|c|c|c|c|}
\hline \multirow[b]{2}{*}{ Year of Shipment } & \multicolumn{2}{|c|}{ Amount to be Shipped } & \multicolumn{2}{|c|}{ Change from 1995 to 1996} \\
\hline & $\begin{array}{c}\text { As of } \\
\text { December 31, } 1995\end{array}$ & $\begin{array}{c}\text { As of } \\
\text { December 31, } 1996\end{array}$ & Annual & Cumulative \\
\hline 1997 ................. & 42,182 & 41,279 & -903 & -903 \\
\hline 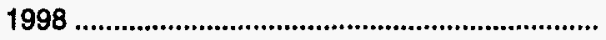 & 52,936 & 49,724 & $-3,212$ & $-4,115$ \\
\hline 1999 & 37,733 & 42,438 & 4,705 & 590 \\
\hline 2000 ............................. & 47,625 & 50,132 & 2,507 & 3,097 \\
\hline 2001 & 35,066 & 39,980 & 4,914 & 8,011 \\
\hline $2002 \ldots . . . \ldots \ldots \ldots . . . . .$. & 38,340 & 39,425 & 1,085 & 9,096 \\
\hline 2003 & 36,206 & 35,469 & -737 & 8,359 \\
\hline $2004 \ldots \ldots \ldots$ & 40,353 & 38,481 & $-1,872$ & 6,487 \\
\hline 2005 & 30,373 & 32,601 & 2,228 & 8,715 \\
\hline 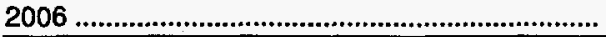 & NR & 34,424 & 一 & 一 \\
\hline
\end{tabular}

NR=Not reported. $-=$ Not applicable.

Source: Energy Information Administration, Form ElA-858, "Uranium Industry Annual Survey" (1995-1996). 
Table 25. U.S. Utilities Purchases of Enrichment Services by Country and Delivery Year, 1994-1996

(Thousand Separative Work Units (SWU))

\begin{tabular}{|c|c|c|c|}
\hline Actual Deliveries & 1994 & 1995 & 1996 \\
\hline \multicolumn{4}{|l|}{ Country where Enrichment Service was performed: } \\
\hline $\begin{array}{l}\text { China } \\
\text { Ferance . } \\
\text { Netherlands } \\
\text { Russia } \\
\text { South Africa } \\
\text { United Kingdom }\end{array}$ & $\begin{array}{r}237 \\
549 \\
W \\
W \\
421 \\
0 \\
W\end{array}$ & $\begin{array}{r}0 \\
867 \\
W \\
W \\
1,108 \\
0 \\
460\end{array}$ & $\begin{array}{r}W \\
1,507 \\
W \\
167 \\
1,073 \\
0 \\
278\end{array}$ \\
\hline Foreign Total & 1,676 & 2,800 & 3,154 \\
\hline United States & 7,521 & 6,741 & 8,004 \\
\hline Total & 9,197 & 9,540 & 11,159 \\
\hline
\end{tabular}

W=Data withheld to avoid disclosure.

Note: Totals may not equal sum of components because of independent rounding.

Source: Energy Information Administration, Form ElA-858, "Uranium Industry Annual Survey" (1994-1996).

Table 26. U.S. Utilities Purchases of Enrichment Services by Contract Type in Delivery Year 1996 (Thousand Separative Work Units (SWU))

\begin{tabular}{|c|c|c|c|}
\hline Enrichment Service Contract Type & U.S. Enrichment & Foreign Enrichment & Total \\
\hline Spot & W & W & W \\
\hline Short-term & $w$ & 0 & w \\
\hline Medium-term & W & w & 951 \\
\hline Long-term & 7,812 & 1,959 & 9,771 \\
\hline 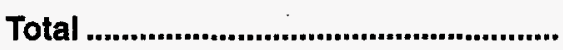 & 8,004 & 3,154 & 11,159 \\
\hline
\end{tabular}

Note: Totals may not equal sum of components because of independent rounding.

Source: Energy Information Administration, Form EIA-858, "Uranium Industry Annual Survey" (1996).

Table 27. Uranium in Fuel Assemblies Loaded into U.S. Commercial Nuclear Reactors by Year, 1994-1996

(Thousand Pounds $\mathrm{U}_{3} \mathrm{O}_{8}$ Equivalent)

\begin{tabular}{|c|c|c|c|}
\hline Origin of Uranium & 1994 & 1995 & $1996^{\mathrm{P}}$ \\
\hline $\begin{array}{l}\text { Domestic-Origin Uranium } \\
\text { Foreign-Orign Uranium }\end{array}$ & $\begin{array}{r}9,302 \\
31,098\end{array}$ & $\begin{array}{l}11,146 \\
39,972\end{array}$ & $\begin{array}{r}8,720 \\
36,740\end{array}$ \\
\hline Total & 40,400 & 51,118 & 45,460 \\
\hline
\end{tabular}

$P=$ Preliminary data. Final 1995 fuel assembly data reported in the 1996 survey.

Notes: Includes only unirradiated uranium in new fuel assemblies loaded into reactors during the year. Does not include uranium removed from reactors that subsequently will be reloaded. Totals may not equal sum of components because of independent rounding.

Source: Energy Information Administration, Form ElA-858, "Uranium Industry Annual Sunvey" (1995-1996). 
Table 28. Imports of Uranium by U.S. Suppliers, U.S. Utilities and Delivery Year, 1994-1996

\begin{tabular}{|c|c|c|c|}
\hline Actual Deliveries & 1994 & 1995 & 1996 \\
\hline $\begin{array}{l}\text { U.S. Suppliers: } \\
\text { Foreign Purchases (Imports) } \\
\text { Weighted-Average Price }\end{array}$ & $\begin{array}{r}21,082 \\
7.78\end{array}$ & $\begin{array}{r}20,162 \\
8.96\end{array}$ & $\begin{array}{r}21,746 \\
11.78\end{array}$ \\
\hline 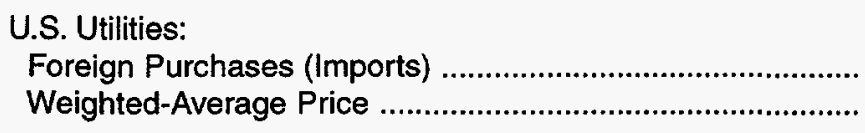 & $\begin{array}{r}15,536 \\
10.53\end{array}$ & $\begin{array}{r}21,139 \\
11.39\end{array}$ & $\begin{array}{r}23,676 \\
14.41\end{array}$ \\
\hline 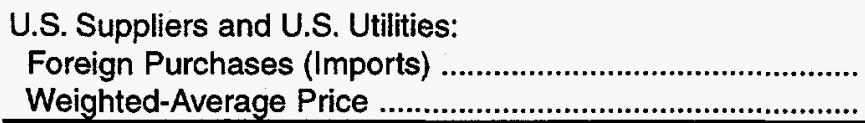 & $\begin{array}{r}36,618 \\
8.95 \\
\end{array}$ & $\begin{array}{r}41,301 \\
10.20 \\
\end{array}$ & $\begin{array}{r}45,422 \\
13.15 \\
\end{array}$ \\
\hline
\end{tabular}

Source: Energy Information Administration, Form EIA-858, "Uranium Industry Annual Survey" (1994-1996).

Table 29. U.S. Brokers and Traders Purchases of Uranium by Material Origin, Supplier, and Delivery Year, 1994-1996

(Thousand Pounds $\mathrm{U}_{3} \mathrm{O}_{8}$ Equivalent; Dollars per Pound $\mathrm{U}_{3} \mathrm{O}_{8}$ Equivalent)

\begin{tabular}{|c|c|c|c|}
\hline Actual Deliveries & 1994 & 1995 & 1996 \\
\hline \multicolumn{4}{|l|}{ Received by U.S. Brokers and Traders of U.S.-Origin Uranium: } \\
\hline Purchases & 4,792 & 3,356 & 4,725 \\
\hline Weighted-Average Price & 9.75 & 11.51 & 13.90 \\
\hline \multicolumn{4}{|l|}{ Received by U.S. Brokers and Traders of Foreign-Origin Uranium: } \\
\hline Purchases & 26,011 & 19,593 & 20,529 \\
\hline Weighted-Average Price ............................................ & 8.02 & 9.20 & 12.32 \\
\hline \multicolumn{4}{|l|}{ Total Received by U.S. Brokers and Traders: } \\
\hline 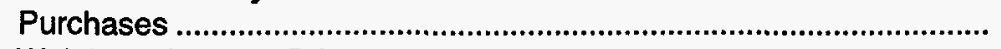 & 30,803 & 22,949 & 25,254 \\
\hline Weighted-Average Price & 8.29 & 9.53 & 12.61 \\
\hline \multicolumn{4}{|l|}{ Received by U.S. Brokers and Traders from Foreign Suppliers: } \\
\hline Purchases & 22,328 & 18,311 & 17,816 \\
\hline Weighted-Average Price & 7.87 & 9.02 & 11.78 \\
\hline
\end{tabular}

Source: Energy Information Administration, Form EIA-858, "Uranium Industry Annual Survey" (1994-1996). 
Table 30. Uranium Exports to Foreign Suppliers and Utilities by Origin andDelivery Year, 1994-1996

(Thousand Pounds $\mathrm{U}_{3} \mathrm{O}_{8}$ Equivalent; Dollars per Pound $\mathrm{U}_{3} \mathrm{O}_{8}$ Equivalent)

\begin{tabular}{|c|c|c|c|}
\hline Actual Deliveries to Foreign Suppliers and Utilities & 1994 & 1995 & 1996 \\
\hline \multicolumn{4}{|l|}{ U.S.-Origin Uranium: } \\
\hline 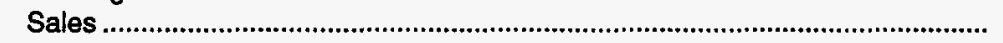 & 5,941 & 4,713 & 4,962 \\
\hline Weighted-Average Price & 18.41 & 17.34 & 17.22 \\
\hline \multicolumn{4}{|l|}{ Foreign-Origin Uranium: } \\
\hline 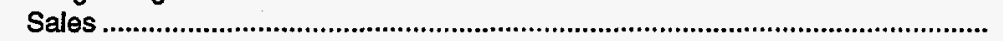 & 11,799 & 5,123 & 6,542 \\
\hline 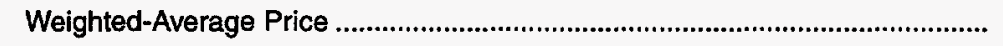 & 7.78 & 9.94 & 11.91 \\
\hline \multicolumn{4}{|l|}{ Total Exports: } \\
\hline Sales & 17,740 & 9,836 & 11,504 \\
\hline 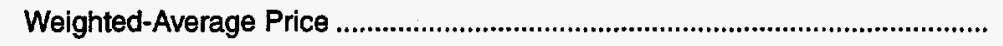 & 11.34 & 13.48 & 14.20 \\
\hline \multicolumn{4}{|l|}{ Exports by U.S. Producers, U.S. Utilities, and Other U.S. Suppliers: } \\
\hline Sales & 4,930 & 4,342 & 5,539 \\
\hline 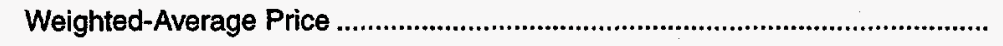 & 20.09 & 18.11 & 15.69 \\
\hline \multicolumn{4}{|l|}{ Exports by U.S. Brokers and Traders: } \\
\hline 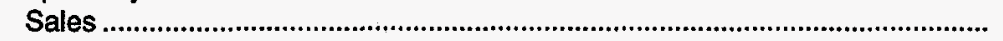 & 12,810 & 5,494 & 5,965 \\
\hline 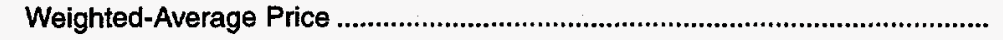 & 7.98 & 9.83 & 12.82 \\
\hline
\end{tabular}

Note: "Other U.S. Suppliers" are U.S. converters, enrichers, and fabricators.

Source: Energy Information Administration, Form EIA-858, "Uranium Industry Annual Survey" (1994-1996).

Table 31. Inventories of Natural and Enriched Uranium as of End of Year, 1994-1996 (Thousand Pounds $\mathrm{U}_{3} \mathrm{O}_{8}$ Equivalent)

\begin{tabular}{|c|c|c|c|}
\hline \multirow[b]{2}{*}{ Type of Uranium Inventory } & \multicolumn{3}{|c|}{ Inventories at the End of the Year } \\
\hline & 1994 & 1995 & $1996^{P}$ \\
\hline 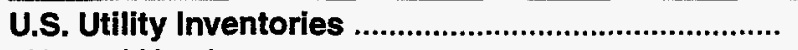 & 65,410 & R58,730 & 67,502 \\
\hline Natural Uranium & 42,417 & R41,227 & 42,215 \\
\hline 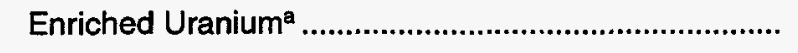 & 22,993 & $\mathrm{R} 17,504$ & 25,287 \\
\hline U.S. Supplier Inventories & 21,469 & R13,740 & 13,687 \\
\hline Natural Uranium & 17,413 & R13,218 & 12,970 \\
\hline 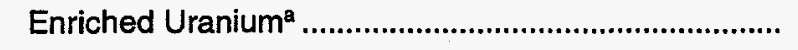 & 4,056 & R521 & 717 \\
\hline 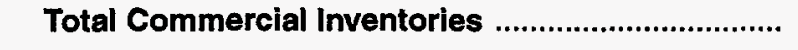 & 86,879 & $\mathbf{R 7 2 , 4 7 0}$ & 81,189 \\
\hline 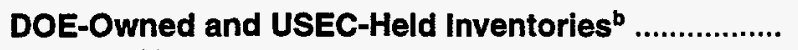 & 85,210 & $\mathbf{R} 110,797$ & 107,687 \\
\hline Natural Uranium & 57,176 & $\mathrm{R} 81,987$ & 82,407 \\
\hline Enriched Uranium & 28,034 & 28,810 & 25,280 \\
\hline
\end{tabular}

ancludes amounts reported as inventories of UF at Enrichment Suppliers.

Includes amounts reported as inventories by U.S. Department of Energy (DOE) and the United States Enrichment Corporation (USEC).

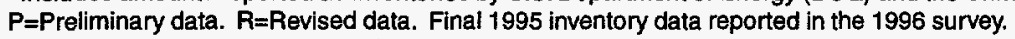

Note: Totals may not equal sum of components because of independent rounding.

Source: Energy Information Administration, Form ElA-858, "Uranium Industry Annual Survey" (1995-1996). 
Table 32. Commercial Uranium Inventories by Type and Location at End of Year, 1994-1996 (Thousand Pounds $\mathrm{U}_{3} \mathrm{O}_{8}$ Equivalent)

\begin{tabular}{|c|c|c|c|c|c|c|c|c|c|}
\hline \multirow[b]{2}{*}{ Material Type and Location } & \multicolumn{3}{|c|}{ U.S. Utilities } & \multicolumn{3}{|c|}{ U.S. Suppliers } & \multicolumn{3}{|c|}{$\begin{array}{l}\text { U.S. Utilities and } \\
\text { U.S. Suppliers }\end{array}$} \\
\hline & 1994 & 1995 & $1996^{P}$ & 1994 & 1995 & $1996^{P}$ & 1994 & 1995 & $1996^{P}$ \\
\hline $\begin{array}{l}\mathrm{U}_{3} \mathrm{O}_{8} \text { on hand, in off-site storage, or } \\
\text { at conversion plants }\end{array}$ & 21,296 & $\mathbf{R 2 3 , 5 3 6}$ & 25,475 & 13,084 & $\mathbf{R} 11,308$ & 11,598 & 34,380 & $\mathbf{R 3 4 , 8 4 4}$ & 37,073 \\
\hline $\begin{array}{l}\text { Natural UF } \\
\text { on hand, in private off-site storage, or }\end{array}$ & 21,121 & $\mathrm{R} 17,690$ & 16,740 & 4,329 & $\mathbf{R 1 , 9 1 0}$ & 1,372 & 25,450 & R19,601 & 18,113 \\
\hline 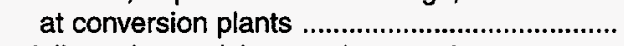 & $w$ & $w$ & W & W & w & W & 5,085 & $\mathrm{R} 5,422$ & 3,665 \\
\hline $\begin{array}{l}\text { delivered to enrichment plants under } \\
\text { usage agreements }\end{array}$ & W & W & W & W & W & W & 11,398 & 6,102 & 9,364 \\
\hline at enrichment suppliers ........................................... & 6,989 & R7,056 & 4,236 & 1,978 & 1,020 & 848 & 8,967 & $R 8,076$ & 5,084 \\
\hline Enriched UF ${ }_{6}$ & 22,993 & R17,504 & 25,287 & 4,056 & R521 & 717 & 27,049 & R18,025 & 26,004 \\
\hline at enrichment suppliers & W & W & W & W & W & W & 3,945 & $\mathrm{R} 2,007$ & 2,544 \\
\hline $\begin{array}{l}\text { on hand, and/or in private storage } \\
\text { as fabricated fuel not inserted into a................ }\end{array}$ & W & W & W & W & W & W & 8,874 & $\mathrm{R} 8,286$ & 13,765 \\
\hline reactor, on hand, and/or in private storage ....... & 14,231 & 7,733 & 9,695 & 0 & 0 & 0 & 14,231 & 7,733 & 9,695 \\
\hline Total Commercial Inventories. & 65,4 & 58,730 & 67,502 & 21,46 & 13,740 & 13,687 & 86,879 & $\mathrm{R} 72,470$ & 81,189 \\
\hline
\end{tabular}

P = Preliminary data. $R=$ Revised data. Final 1995 inventory data reported in the 1996 survey. $W=D a t a$ withheld to avoid disclosure. Note: Totals may not equal sum of components because of independent rounding.

Source: Energy Information Administration, Form EIA-858, "Uranium Industry Annual Survey" (1995-1996).

Table 33. Commercial Uranium Inventories by Type and Owner at End of Year, 1994-1996 (Thousand Pounds $\mathrm{U}_{3} \mathrm{O}_{8}$ Equivalent)

\begin{tabular}{|c|c|c|c|c|c|c|c|c|c|}
\hline \multirow[b]{2}{*}{ U.S. Firms } & \multicolumn{3}{|c|}{$\mathrm{U}_{3} \mathrm{O}_{8}$} & \multicolumn{3}{|c|}{ Natural and Enrich $\mathrm{UF}_{6}$} & \multicolumn{3}{|c|}{ Total } \\
\hline & 1994 & 1995 & $1996^{P}$ & 1994 & 1995 & $1996^{P}$ & 1994 & 1995 & $1996^{P}$ \\
\hline Brokers and Traders ........................... & 7,480 & 5,404 & W & 4,250 & $\mathrm{R} 1,405$ & W & 11,729 & $R 6,808$ & 6,557 \\
\hline Converter and Fabricators .................. & 0 & 0 & W & 4,136 & 1,027 & $w$ & 4,136 & 1,027 & 1,254 \\
\hline 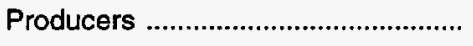 & 5,604 & R5,904 & 5,876 & 0 & 0 & 0 & 5,604 & $\mathrm{R} 5,904$ & 5,876 \\
\hline 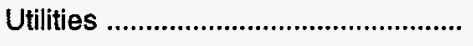 & 21,296 & $\mathrm{R} 23,536$ & 25,475 & 44,114 & $\mathrm{R} 35,194$ & 42,027 & 65,410 & $\mathrm{R} 58,730$ & 67,502 \\
\hline Total Commercial Inventories ........ & 34,380 & R34,844 & 37,073 & 52,499 & R37,626 & 44,116 & 86,879 & R72,470 & 81,189 \\
\hline
\end{tabular}

$P=$ Preliminary data. $R=$ Revised data. Final 1995 inventory data reported in the 1996 survey. $W=D a t a$ withheld to avoid disclosure.

Note: Totals may not equal sum of components because of independent rounding.

Source: Energy Information Administration, Form ElA-858, "Uranium Industry Annual Survey" (1995-1996). 

Appendix A

Survey

Methodology 



\section{Appendix A \\ Survey Methodology}

\section{Survey Design}

The 13th comprehensive survey of the U.S. uranium industry was conducted in 1997 by the Energy Information Administration (EIA) using the "Uranium Industry Annual Survey," Form EIA-858. EIA collected data from all companies involved in the U.S. uranium industry, mailing the survey form to these firms in December 1996. The data reported in this publication were developed from the 1996 survey and predecessor databases.

EIA asked respondents to the "Uranium Industry Annual Survey" to provide data current to the end of 1996 about the following:

Uranium raw materials activities, including: land holdings, exploration and development activities, uranium-bearing properties and reserves, uranium mines, uranium processing facilities, and uranium industry employment in the raw materials sector

Uranium marketing activities, including contracts, contract prices and delivery schedules, uranium inventories, enrichment feed deliveries, unfilled market requirements, uranium used in fuel assemblies, and purchases of enrichment services.

The data collected on Form EIA-858 are subject to various sources of error. These sources are: (1) coverage (the list of respondents might not be complete or, on the other hand, there might be double counting); (2) non-response (all units that are surveyed might not respond or not provide all the information requested); (3) respondents (respondents might commit errors in reporting the data); (4) processing (the data collection agency might omit or incorrectly transcribe a submission); (5) concept (the data collection elements might not measure the items they were intended to measure); and (6) adjustments (errors might be made in estimating values for missing data). Because the "Uranium Industry Annual Survey" is not a sample survey, the estimates shown in this report are not subject to sampling error. ${ }^{1}$ Although it is not possible to present estimates of nonsampling error, precautionary steps were taken at each stage of the survey design to minimize the possible occurrence of these errors. The steps are described below, with the error they were designed to minimize shown in parenthesis.

\section{Survey Universe and Frame (Coverage Errors)}

The survey universe includes all companies involved in the U.S. uranium industry. The universe includes all firms meeting one or more of the following criteria: (1) are controllers or were controllers during any portion of 1996 , or are identified in EIA records as the most recent controllers of uranium properties, mines, mills, or plant; (2) involved as controllers of uranium exploration and development ventures in the United States; (3) incurred uranium exploration expenditures in 1996 or plan such expenditures in 1997; (4) hold uranium reserves; (5) control uranium mining properties; (6) control commercial uranium extraction operations; and (7) purchase, sell, held, or own domestic- or foreign-origin uranium; offered uranium enrichment services; imported or exported uranium; and (utilities only) purchased uranium enrichment services from an enrichment supplier.

The respondent list used for the Form EIA-858 survey was developed from a frame of all establishments known to meet the selection criteria. The frame of potential respondents was compiled from previous surveys and from information in the public domain. The frame was intended to cover the following: all utilities owning nuclear-fueled generating stations; uranium converters, enrichers, and fuel fabricators; uranium traders and brokers; large and small companies actively engaged in exploration, development, or extraction in the U.S. uranium industry; and companies holding all large properties with uranium reserves. Companies meeting these criteria include: those involved in exploration, development, mining, milling, and trading of uranium; landowners; uranium converters, enrichers, and fabricators; and utilities with whole or partial ownership in operating or planned nuclear electric power plants.

\section{Survey Procedures (Nonresponse)}

The survey forms were sent via first class mail to ensure their receipt only by the proper respondent organization. If the U.S. Postal Service was unable to deliver the survey form, the corrected address was obtained where possible. In a few instances, businesses that had reported in earlier surveys were no longer operating. All known companies

'Sampling error is a measure of the variation that occurs by chance because a sample rather than a complete enumeration of units is surveyed. 
currently conducting business in the U.S. uranium industry were contacted during this survey.

Form EIA-858, "Uranium Industry Annual Survey," requests data about many areas of company operations. The scope of the questions is necessarily broad, and self-reporting of company-specific data is required.

Cooperation from industry on the 1996 survey was good. About 48 percent of respondents replied to the form within the specified deadline. Those that had not responded by the due date (March 1st for Schedules A and B) were telephoned to encourage submission of the forms, and those calls resulted in the submission of most of the remaining forms. Subsequently, telephone calls were made to obtain forms not yet submitted. In a few instances, company data were collected through telephone conversations.

\section{Data Editing, Analysis, and Processing (Respondent and Processing Errors)}

The survey forms are logged in and reviewed by agency personnel prior to data entry into the Uranium Industry Annual System, an automated database containing all current and historical data from each company's submissions. The database is maintained on the EIA computer facility in Washington, DC. After entry into the database, a copy of each part of the Form EIA-858 was distributed to the Analysis and Systems Division analyst responsible for that part. The submissions were checked for internal consistency, and the reported data were compared with previous collections of similar data. After reviewing these submissions, the analyst consulted with the reporting company, as needed, to resolve data problems and to confirm any corrections of the data.

Data areas that were reviewed and the corrections that were made differed from company to company. Most represented different interpretations of the data item definitions. No data in the database were changed without first consulting with the reporting company. Computer edits were also used to identify keypunch errors, out-of-range values, and unlikely data combinations. These also were either corrected to represent the data reported on the submissions or were changed only after confirming the corrected values by telephone conversations with company representatives. Data coding and entry errors were eliminated by proofing data after entry. All changes to reported data are documented.

\section{Response Rates}

For the 1996 Form EIA-858 survey, Schedule A, "Uranium Raw Materials Activities," was mailed to 47 firms and Schedule B, "Uranium Marketing Activities," was mailed to 85 firms. Response statistics are shown in Table A1. Overall, 100 percent of the firms responded to EIA with the data as requested for the survey sections as applicable to individual firms.

Table A1. Response Statistics for the 1996 Uranium Industry Annual Survey

\begin{tabular}{c|c|c}
\hline \multirow{2}{*}{ Response Status } & \multicolumn{2}{|c}{ Schedule } \\
\cline { 2 - 3 } & A & B \\
\hline Survey Schedules Mailed Out ............. & 47 & 85 \\
Data Provided ................................ & 41 & 82 \\
Reported as Not Applicable ............. & 6 & 3 \\
\hline
\end{tabular}

Source: Energy Information Administration, Form ElA-858, "Uranium Industry Annual Survey" (1996).

\section{Missing Data}

Some omissions of data were identified during the prescreening and editing of the data. Most omitted data elements fell into two categories: particular data were unknown or inadvertent omissions. EIA contacted respondents to obtain omitted data or to verify that they could not be reported. Only confirmed company-reported data are contained in the database and included in this report.

\section{Data Revisions}

The Office of Coal, Nuclear, Electric and Alternate Fuels, Energy Information Administration, has adopted the following policy for review and correction (revision) of data it collects and publishes. The policy covers revisions to prior published data. This new policy was initially implemented with the publication of the Uranium Industry Annual 1992.

1. Annual survey data are published either as preliminary or final when they first appear in a data report. Data released as preliminary will be identified as such. When necessary, preliminary data will be revised and declared to be final at the next publication of that data.

2. Monthly and quarterly survey data are published 
initially as preliminary data. They will be revised only after the completion of the data collection cycle for the full 12-month survey period. Revisions will not be made to monthly or quarterly data prior to this time.

3. The magnitude of historical data revisions experienced will be included in each data report to inform the reader about the accuracy of the data presented.

4. Revisions to data published as final will be made only in the event that newly available information would result in a change to published data of more than than 1 percent at the national level. Revisions for changes of lesser magnitudes will be made at the discretion of the Office Director.

All data, except for uranium inventory data and uranium fuel assembly data, are published as final. Data on uranium inventories and fuel assemblies for the survey year are published as preliminary because survey respondents are requested to make changes to their prior year data, if necessary, when reporting data for the current survey year. These revised data are indicated by an " $R$ " in front of the revised table cell.

Changes to the prior year's total commercial uranium inventory figures based on revisions reported on Form EIA858 was for $1995,2.3$ million pounds $\mathrm{U}_{3} \mathrm{O}_{8}$ e (3.3 percent).

\section{Nondisclosure of Data}

To protect the confidentiality of individual respondents' data, a policy was implemented to ensure that the reporting of survey data in this publication would not associate those data with a particular company. This is in compliance with EIA Standard No. 88-05-06, "Nondisclosure of Company Identifiable Data in Aggregate Cells." In tables where the nonzero value of a cell is composed of data from fewer than three companies or if a single company dominates a table-cell value so that the publication of the value would lead to identification of a company's data, then the EIA classifies the cell value as "sensitive," and the cell value is withheld ("W") from publication. Within a table with a sensitive cell value, selected values in other cells of the table are also withheld, as necessary, so that the sensitive cell value cannot be computed using the values in published cells. A sensitive table-cell value can be reported, if each company whose data contribute to the sensitivity, gives permission to publish the value and if the company believes that publishing it would not harm the company's competitive position. This is the only exception to the application of EIA Standard No. 88-05-06 in this report. 

Appendix B

Resources and Reserves 



\section{Appendix B}

\section{Resources and Reserves}

This section discusses the methodologies used to estimate the U.S. uranium resources. Three classes of resources are estimated: Reserves, Estimated Additional Resources (EAR), and Speculative Resources (SR). EAR and SR categories are undiscovered potential.

A diagram showing a comparison of nomenclatural schemes used by the EIA and DOE's predecessor agencies for reporting estimates of U.S. uranium resources since 1974 is provided in Figure B1.

\section{Appraisal of Potential Resources}

The appraisal of the National potential resources of uranium, which comprise the Estimated Additional Resources (EAR) and Speculative Resources (SR) categories, is based on extensive data collected under the uranium resource appraisal program of DOE and its predecessor agencies. These data include: chemical assays of core samples; data from geochemical surveys of groundwater, stream water and sediment; aerial radiometric surveys; limited selective drilling to fill voids in subsurface information; and geological studies of field areas throughout the United States.

Estimates of potential resources are based on data developed under the DOE National Uranium Resource Evaluation (NURE) program and under a Memorandum of Understanding signed in 1984 between EIA and the U.S. Geological Survey of the Department of Interior. Annual updating of the estimates by EIA was discontinued after 1994. Therefore, 1995 potential resources are the same as those reported for the previous year. Estimates of uranium resources in the EAR and SR classes for 1986 through 1995 are shown in Table B1. Resource quantities of EAR and SR are summarized for principal resource regions and forward-cost categories in Table B2.

\section{Estimation of Reserves}

Uranium reserves are the estimated quantities of uranium that occur in known deposits of such grade, quantity, configuration, and depth that they can be recovered under current regulations at or below a specified cost with stateof-the-art mining and processing technology. Estimated reserves are based on direct radiometric and chemical measurements in drill hole samples. Ore grades and thickness, spacial relationships, depths, mining and reclamation methods, haulage distance, and amenability of ore within specific forward-cost levels are considered in the evaluation. Uranium reserves estimated by the DOE have been adjusted for appropriate mining dilution and mill recovery.

The costs used to categorize uranium reserves are forward costs (see Glossary) in current (year of estimate) dollars that would be incurred in producing the uranium. The costs include power and fuel, labor, materials, royalties, severance and ad valorem taxes, insurance, and applicable administrative costs. Previous expenditures (sunk costs) for such item as exploration and land acquisition are excluded. Also excluded are income taxes, profit, and the cost of money. The forward-cost categories are independent of the market price at which the uranium might be sold.

The current uranium reserve estimates are based on a combination of EIA-held historical property data, companyreported data, and independent reserve estimates. The estimates of national uranium reserves also are based on current knowledge about domestic deposits and on adjustments for depletion and erosion of specific cost category reserves due to production of ore from individual property. Current and historical estimates of reserves since 1986 are shown in Table B3. Reserve estimates of each forward-cost category are summarized for major States in Table B4. 
Figure B1. Comparison of Historical and Current U.S. and NEAIAEA Classification Nomenclature for Uranium Resources
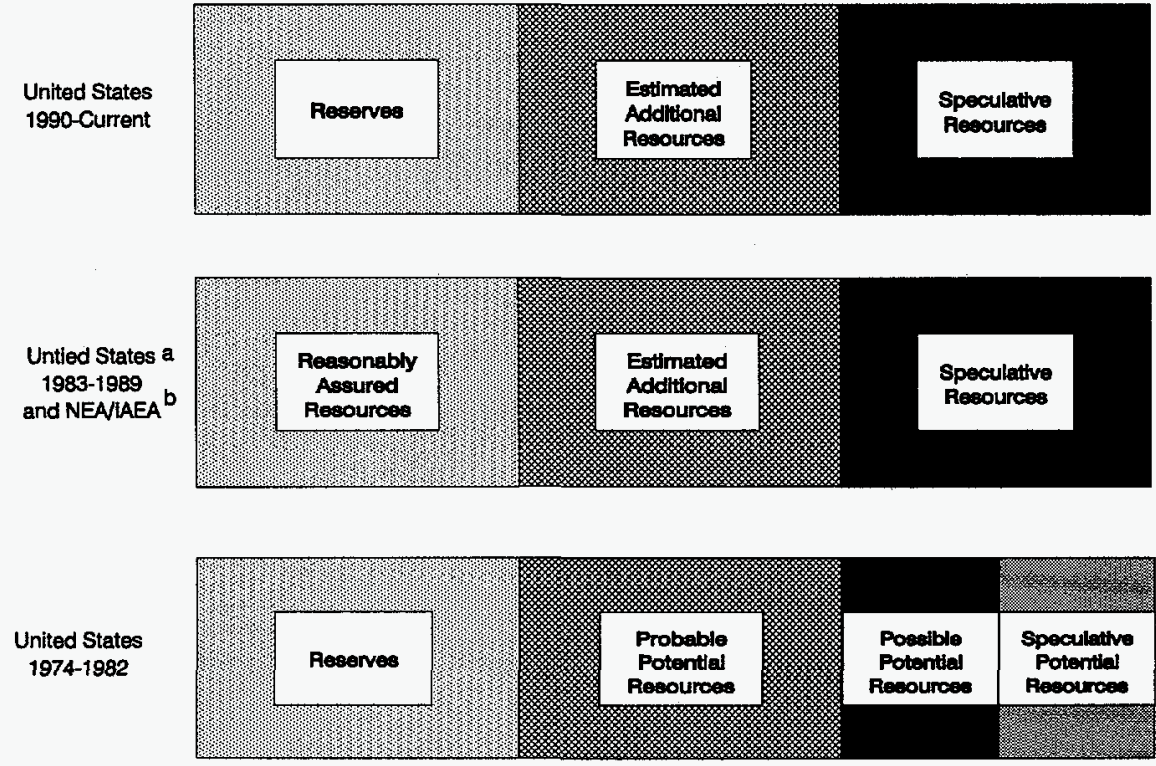

aThis nomenclature was adopted in 1983 by the U.S. Department of Energy and was patterned after the Nuclear Energy Agency/International Atomic Energy Agency Standard.

The classifications shown for the United States prior to 1983 and after 1989 and the NEAIAEA are not strictly comparable, because the criteria used in the individual systems are not identical. Precise correlations are not possible, particularly for the less assured resources. Nonetheless, based on the principal criterion of geological assurance of existence, this figure presents a reasonable approximation of uranium resources classification comparability.

DNEAIIAEA: Nuclear Energy Agency/International Atomic Energy Agency.

Note: The NEAIAEA separates the Estimated Additional Resources (EAR) into Categories I and II based primarily on geological inference. Categories I and II of EAR are not utilized for estimates of resources in the United States.

Source: Prepared by the Energy Information Administration, Office of Coal, Nuclear, Electric and Alternate Fuels.

Figure B2. Uranium Resource Regions of the United States

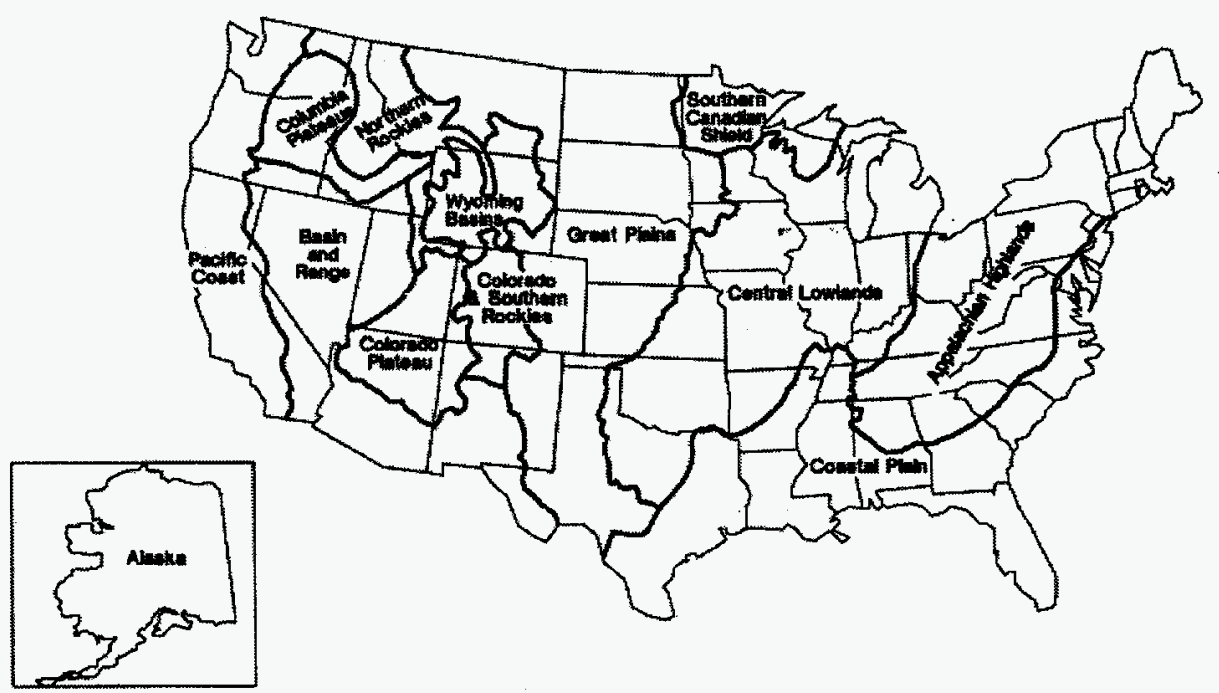

Source: U.S. Department of Energy, An Assessment Report on Uranium in the United States of America, GJO-111(80) (Grand Junction, Colorado, October 1980). 
Table B1. U.S. Potential Uranium Resources by Forward-Cost Category and Resource Class, 1987-1996

(Million Pounds $\mathrm{U}_{3} \mathrm{O}_{8}$ )

\begin{tabular}{|c|c|c|c|c|c|c|}
\hline \multirow[b]{3}{*}{ Year } & \multicolumn{6}{|c|}{ Forward-Cost Category } \\
\hline & \multicolumn{2}{|c|}{$\$ 30$ per pound } & \multicolumn{2}{|c|}{$\$ 50$ per pound } & \multicolumn{2}{|c|}{$\$ 100$ per pound } \\
\hline & EAR $^{\mathrm{a}}$ & $\mathrm{SR}^{b}$ & EAR $^{\mathbf{a}}$ & $\mathrm{SR}^{\mathrm{b}}$ & EAR $^{\mathrm{a}}$ & $S^{b}$ \\
\hline 1987 & 1,300 & 1,000 & 2,300 & 2,000 & 3,700 & 3,200 \\
\hline 1988 & 1,300 & 1,000 & 2,300 & 2,000 & 3,800 & 3,200 \\
\hline 1989 & 2,300 & 1,400 & 3,400 & 2,300 & 5,000 & 3,500 \\
\hline 1990 & 2,200 & 1,300 & 3,400 & 2,200 & 4,900 & 3,500 \\
\hline 1991 & 2,200 & 1,400 & 3,400 & 2,300 & 4,900 & 3,600 \\
\hline 1992 & 2,200 & 1,300 & 3,400 & 2,300 & 4,900 & 3,500 \\
\hline 1993 & 2,200 & 1,330 & 3,340 & 2,250 & 4,880 & 3,510 \\
\hline 1994 & 2,180 & 1,310 & 3,310 & 2,230 & 4,850 & 3,480 \\
\hline 1995 & 2,180 & 1,310 & 3,310 & 2,230 & 4,850 & 3,480 \\
\hline 1996 & 2,180 & 1,310 & 3,310 & 2.230 & 4,850 & 3,480 \\
\hline
\end{tabular}

"EAR $=$ Estimated Additional Resources.

'SR = Speculative Resources.

Notes: Values shown are the mean values for the distribution of estimates for each forward-cost category: 1987-1992- rounded to the nearest 100 million pounds $\mathrm{U}_{3} \mathrm{O}_{8} ;$ 1993-1996- rounded to the nearest 10 million pounds $\mathrm{U}_{3} \mathrm{O}_{8}$. Estimates of uranium that could be recovered as a byproduct of other commodjties are not included. Resource values in fonward-cost categories are cumulative: that is, the quantity at each level of forward cost includes all resources at the lower cost in that category.

Sources: 1987-1988-Estimates based on uranium resources data developed under the DOE National Uranium Resource Evaluation (NURE) program, 1974-1983, using methodology described in An Assessment Report on Uranium in the United States of America (October 1980) in U.S. Department of Energy, Uranium Industry Seminar (October 1980); and under U. S. Geological Survey (USGS) Uranium Resource Assessment Project. 1989-1996Estimates based on uranium resources data develpoed under the NURE program and USGS Uranium Resource Assessment Project using methodology described in Uranium Resource Assessment by the Geological Survey: Methodology and Plan to Update the National Resource Base, U.S. Geological Survey Circular 994 (1987). Estimates are updated annually by EIA using revised economic index values which reflect changes in the U.S. economy.

Table B2. U.S. Potential Uranium Resources by Forward-Cost Category and Resource Region, 1996 (Million Pounds $\mathrm{U}_{3} \mathrm{O}_{8}$ )

\begin{tabular}{|c|c|c|c|c|c|c|}
\hline \multirow[b]{3}{*}{ Resource Region } & \multicolumn{6}{|c|}{ Forward-Cost Category } \\
\hline & \multicolumn{2}{|c|}{$\$ 30$ per pound } & \multicolumn{2}{|c|}{$\$ 50$ per pound } & \multicolumn{2}{|c|}{$\$ 100$ per pound } \\
\hline & $\mathrm{EAR}^{\mathrm{a}}$ & $\mathrm{SR}^{\mathrm{b}}$ & $\mathrm{EAR}^{\mathrm{a}}$ & $S^{b}$ & EAR $^{a}$ & $\mathrm{SR}^{\mathrm{b}}$ \\
\hline Colorado Plateau ....................................... & 1,330 & 480 & 1,900 & 770 & 2,540 & 1,210 \\
\hline 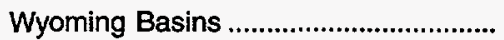 & 160 & 80 & 340 & 160 & 660 & 250 \\
\hline Coastal Plain & 370 & 130 & 490 & 180 & 600 & 230 \\
\hline 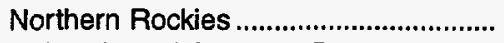 & 30 & 110 & 60 & 200 & 170 & 300 \\
\hline Colorado and Southern Rockies ........... & 140 & 90 & 180 & 140 & 220 & 190 \\
\hline Basin and Range & 50 & 90 & 160 & 170 & 390 & 320 \\
\hline 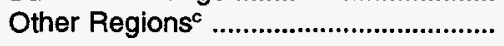 & 110 & 330 & 180 & 610 & 270 & 990 \\
\hline Total & 2,180 & 1,310 & 3,310 & 2,230 & 4,850 & 3,480 \\
\hline
\end{tabular}

-EAR = Estimated Additional Resources.

bSR $=$ Speculative Resources.

cIncludes Appalachian Highlands, Great Plains, Pacific Coast and Sierra Nevada, Central Lowlands, and Columbia Plateau regions and Alaska.

Notes: Values shown are the mean values for the distribution of estimates for each forward-cost category, rounded to the nearest 10 million pounds $\mathrm{U}_{3} \mathrm{O}_{\mathrm{a}}$. Estimates of uranium that could be recovered as a byproduct of other commodities are not included. Resource values in forward-cost categories are cumulative: that is, the quantity at each level of forward cost includes all resources at the lower cost in that category.

Sources: Prepared by the Energy Information Administration, Office of Coal, Nuclear, Electric and Alternate Fuels, based on uranium resources data developed under DOE National Uranium Resource Evaluation (NURE) program and the USGS Uranium Resource Assessment project, using methodology described in Uranium Resource Assessment by the Geological Survey: Methodology and Plan to Update the National Resource Base, U.S. Geological Survey Circular 994 (1987). 
Table B3. U.S. Uranium Reserves by Forward-Cost Category, 1987-1996 (Million Pounds $\mathrm{U}_{3} \mathrm{O}_{8}$ )

\begin{tabular}{|c|c|c|c|}
\hline Year & $\$ 30$ per pound & $\$ 50$ per pound & $\$ 100$ per pound \\
\hline $1987 \ldots \ldots$ & 304 & 1,005 & 1,592 \\
\hline 1988 & 289 & 981 & 1,560 \\
\hline 1989 & 277 & 962 & 1,537 \\
\hline 1990 & 265 & 926 & 1,511 \\
\hline 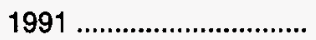 & 304 & 975 & 1,542 \\
\hline 1992 & 295 & 959 & 1,523 \\
\hline $1993 \ldots \ldots$ & 292 & 952 & 1,511 \\
\hline 1994 & 294 & 953 & 1,501 \\
\hline 1995 & 290 & 947 & 1,493 \\
\hline 1996 & 285 & 939 & 1,480 \\
\hline
\end{tabular}

Note: Uranium reserves that could be recovered as a byproduct of phosphate and copper mining are not included in these reserves. Reserves values in forward-cost categories are cumulative; that is, the quantity at each level of forward cost includes all reserves at the lower costs.

Source: Estimated by the Energy Information Administration, Office of Coal, Nuclear, Electric and Alternated Fuels, based on U.S. Department of Energy, Grand Junction Projects Office data files and Energy Information Administration, Form EIA-858, "Uranium Industry Annual Survey" (1987-1996).

Table B4. Forward-Cost Uranium Reserves by State, 1996

\begin{tabular}{|c|c|c|c|c|c|c|}
\hline \multirow[b]{2}{*}{ State(s) } & \multicolumn{3}{|c|}{$\$ 30$ per pound } & \multicolumn{3}{|c|}{$\$ 50$ per pound } \\
\hline & $\begin{array}{c}\text { Ore } \\
\text { (million tons) }\end{array}$ & $\begin{array}{c}\text { Grade } \\
\text { (percent } \mathrm{U}_{3} \mathrm{O}_{8} \text { ) }\end{array}$ & $\mid \begin{array}{c}\mathbf{U}_{3} \mathrm{O}_{8} \\
\text { (million pounds) }\end{array}$ & $\begin{array}{c}\text { Ore } \\
\text { (million tons) }\end{array}$ & $\begin{array}{c}\text { Grade }^{\mathrm{a}} \\
\text { (percent } \mathrm{U}_{3} \mathrm{O}_{8} \text { ) }\end{array}$ & $\begin{array}{c}\mathrm{U}_{3} \mathrm{O}_{8} \\
\text { (million pounds) }\end{array}$ \\
\hline 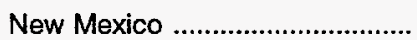 & 15 & 0.279 & 84 & 111 & 0.157 & 350 \\
\hline Wyoming & 44 & 0.131 & 115 & 246 & 0.078 & 384 \\
\hline Arizona, Colorado, Utah .............. & 7 & 0.292 & 43 & 45 & 0.133 & 119 \\
\hline 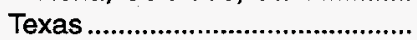 & 5 & 0.087 & 9 & 20 & 0.068 & 27 \\
\hline Otherb & 8 & 0.202 & 34 & 27 & 0.110 & 59 \\
\hline 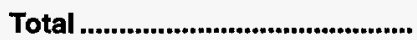 & 80 & 0.178 & 285 & 449 & 0.105 & 939 \\
\hline
\end{tabular}

aWeighted average percent $\mathrm{U}_{3} \mathrm{O}_{8}$ per ton of ore.

includes California, Idaho, Nebraska, Nevada, North Dakota, Oregon, South Dakota, and Washington.

Notes: Uranium reserves that could be recovered as a byproduct of phosphate and copper mining are not included in this table. Reserves values in forward-cost categories are cumulative: that is, the quantity at each level of forward-cost includes all reserves at the lower costs. Totals may not equal sum of components because of independent rounding.

Sources: Estimated by Energy Information Administration, Office of Coal, Nuclear, Electric and Alternate Fuels, based on industry conferences, U.S. Department of Energy, Grand Junction Projects Office data files, and Energy Information Administration, Form ElA-858, "Uranium Industry Annual Survey" (1996). 
Appendix C

Respondents to the Uranium

Industry Annual Survey 



\section{Respondents to the Uranium Industry Annual Survey}

Respondents to the Energy Information Administration's (ELA) 1996 Form EIA-858, "Uranium Industry Annual Survey," are listed alphabetically in Table C1. For each respondent, an industry-activity code (or codes) is shown. The activity code (codes) broadly describes the respondent's major industry activity from Form EIA-858 and from publicly available information. Included in the listing are respondents that stated that no part of the Form EIA-858 was applicable to their operations as of the end of the survey year. The footnote at the end of Table C1 provides an explanation for the activity codes.

Table C1. Respondents to the 1996 Uranium Industry Annual Survey

\begin{tabular}{|c|c|c|c|}
\hline Company Name & $\begin{array}{c}\text { Industry } \\
\text { Activity } \\
\text { Code }^{a}\end{array}$ & Company Name & $\begin{array}{c}\text { Industry } \\
\text { Activity } \\
\text { Code }^{a}\end{array}$ \\
\hline Alabama Power Co. (Southern Nuclear) & UTL & Enserch Processing, Inc. & UPH \\
\hline Aspen Exploration Corporation & UPH & Entergy Operations, Inc. & UTL \\
\hline Arizona Public Service Company & UTL & Everest Exploration, Inc. & UPH, MLG \\
\hline B. B. Brooks Company & UPH & Florida Power Corporation & UTL \\
\hline Baltimore Gas \& Electric & UTL & Florida Power \& Light & UTL \\
\hline BGS Mining Company & UPH & Framatome Cogema Fuels & FAB \\
\hline Boston Edison Company & UTL & General Electric Company & FAB \\
\hline Cameco Resources (U.S.) Inc. & UPH & Geomex Minerals, Inc. & UPH \\
\hline Carolina Power \& Light & UTL & Georgia Power Co. (Southern Nuclear) & UTL \\
\hline Centerior Energy Corporation & UTL & GPU Nuclear, Inc. & UTL \\
\hline Cobb Resources Corporation & UPH & William H. B. Graves & UPH \\
\hline COGEMA, Inc. & BRO & Green Mountain Mining Venture & UPH, MLG \\
\hline COGEMA Mining Inc. (Total Minerals Corp.) & UPH, MLG & Homestake Mining Company & UPH \\
\hline Combustion Engineering, Inc. & FAB & Houston Lighting and Power Co. & UTL \\
\hline Commonwealth Edison & UTL & IES Utilities, Inc. - Duane Arnold Energy Center & I UTL \\
\hline Consolidated Edison Co. of NY, Inc. & UTL & Illinois Power Company & UTL \\
\hline Consumers Energy/Palisades Nuclear Plant & UTL & IMC - Agrico Cpmpany & MLG \\
\hline ConverDyn & CON & Indiana Michigan Power & UTL \\
\hline Cotter Corporation & UPH, MLG & Intercontinental Energy Company & UPH \\
\hline Crow Butte Resources, Inc. & UPH, MLG & Maine Yankee Atomic Power Co. & UTL \\
\hline Cycle Resources Investment Corp. & BRO & Malapai Resources Company & UPH, MLG \\
\hline Dawn Mining Company & UPH, MLG & Marquez Development Corporation & UPH \\
\hline DOE, Office of Nuclear Energy Science \& Tec & Ch ENR & Mesa, Inc. & UPH \\
\hline Detroit Edison & UTL & Mining Unlimited, Inc. & UPH \\
\hline Duke Power Company & UTL & Nebraska Public Power District & UTL \\
\hline Duquesne Light Company & UTL & New Mexico Arizona Land Company (NZU) & UPH \\
\hline Energy Fuels Nuclear Inc. & UPH, MLG & New York Power Authority & UTL \\
\hline
\end{tabular}


Table C1. Respondents to the 1996 Uranium Industry Annual Survey (Continued)

\begin{tabular}{|c|c|c|c|}
\hline Company Name & $\begin{array}{c}\text { Industry } \\
\text { Activity } \\
\text { Code }^{\mathrm{a}}\end{array}$ & Company Name & $\begin{array}{r}\text { Industry } \\
\text { Activity } \\
\text { Code } \\
\end{array}$ \\
\hline New York Nuclear Corp. /NYNCO Trading & BRO & Siemens Power Corporation - Nuclear Div. & FAB \\
\hline Niagara Mohawk Power Corporation & UTL & Simons Associates & UPH \\
\hline North Atlantic Energy Service Corp. & UTL & South Carolina Electric \& Gas & UTL \\
\hline Northeast Utilities Service Co. & UTL & Southern California Edison Company & UTL \\
\hline Northern States Power Company & UTL & Noah H. \& Diane R. Taylor & UPH \\
\hline Nuclear Fuel Resources, Inc. & TRA & Tennessee Valley Authority & UTL \\
\hline Nuclear Fuel Services, Inc. & UPH & Texas Utilities Electric Company & UTL \\
\hline Nuexco Trading Corporation & TRA, BRO & UG U.S.A., Inc. & TRA \\
\hline Nukem, Inc. & TRA, BRO & Umetco Minerals Corporation & UPH \\
\hline Ohio Edison Co. and Pennsylvania Power & UTL & Union Electric Company & UTL \\
\hline Omaha Public Power District & UTL & United Nuclear Corporation & UPH \\
\hline Pacific Gas \& Electric Company & UTL & United States Enrichment Corporation & ENR \\
\hline Pathfinder Mines Corp. (C/O COGEMA Inc.) & UPH & Uranerz USA, Inc. & BRO, UPH \\
\hline PECO Energy Company & UTL & The Uranium Exchange Company & TRA, BRO \\
\hline Pennsylvania Power \& Light Company & UTL & Uranium King Corporation & UPH \\
\hline Petrotomics Company (C/O Texaco, Inc) & UPH & Uranium Resources Incorporated & UPH, MLG \\
\hline Power Resources, Inc. & UPH, MLG & USX Corporation, Texas Uranium Operations & UPH \\
\hline Public Service Electric \& Gas & UTL & U.S. Energy Corp. (Plateau Resources, Ltd) & UPH, MLG \\
\hline Rajah Ventures, Limited & UPH & Vermont Yankee Nuclear Power Corp. & UTL \\
\hline Rhone Poulenc, Inc. & MLG & Virginia Electric and Power Co. & UTL \\
\hline Rio Algom Mining Corp. & UPH, MLG & Washington Public Power Supply System & UTL \\
\hline Rio Grande Resources Corp. & UPH & Western Nuclear, Inc. & UPH \\
\hline Riverside Public Utility Dept. & UTL & Westinghouse Electric Corporation, CNFD & FAB \\
\hline RME Partners, L. P. & UPH & Wisconsin Electric Power Company & UTL \\
\hline Rochester Gas \& Electric Corporation & UTL & Wisconsin Public Service Corporation & UTL \\
\hline San Diego Gas \& Electric & UTL & WM Mining Company & BRO \\
\hline San Rafael Energy, Inc. & UPH & Wold Nuclear Company, John S. Wold d/b/a & UPH \\
\hline Section 2 Joint Venture-Continental Materials & UPH & Wolf Creek Nuclear Operating Corporation & UTL \\
\hline Sheep Mountain Partners & UPH & & \\
\hline
\end{tabular}

aBRO = Uranium brokerage company; $\mathrm{CON}=$ Uranium conversion service supplier; ENR $=$ Uranium enrichment service supplier; $F A B=$ Uranium fuel fabrication service supplier; MLG = Uranium milling/processing company (can involve ownership of a uranium property); TRA = Uranium trading company; UPH = Uranium property holder (can include activities related to uranium exploration, reserves, reclamation, and/or mining); $U T L=N u c l e a r$ electric utility company.

Source: Prepared by the Energy Information Administration, Office of Coal, Nuclear, Electric and Alternate Fuels, based on information reported on the Form ElA-858 "Uranium Industry Annual Survey" (1996). 
Appendix D

U.S. Customary Units of Measurement, International System of Units (SI), and Selected Data Tables in SI Metric Units 



\section{U.S. Customary Units of Measurement, International System of Units (SI), and Selected Data Tables in SI Metric Units}

Standard Factors for interconversion between U.S. customary units and the International System of Units (SI) are shown in Table D1. These factors are provided as a coherent and consistent set of units for the convenience of the reader in making conversions between U.S. and metric units of measure for data published in this report. Conversion factors are provided only for the U.S. units of measurement quoted in this report.

Table D1. Conversion Factors for U.S. Customary Units and SI Metric Units of Measurement

\begin{tabular}{|c|c|c|}
\hline To convert from: & To: & Multiply by: ${ }^{a}$ \\
\hline \multicolumn{3}{|c|}{ Area } \\
\hline acre & meter ${ }^{2}\left(m^{2}\right)$ & $4,046.9^{\star}$ \\
\hline \multicolumn{3}{|c|}{ Length } \\
\hline $\begin{array}{l}\text { foot }(f t) \\
\text { yard }(y d)\end{array}$ & $\begin{array}{l}\text { meter }(m) \\
\text { meter }(m)\end{array}$ & $\begin{array}{l}0.304801 \\
0.9144^{*}\end{array}$ \\
\hline \multicolumn{3}{|c|}{ Mass } \\
\hline $\begin{array}{l}\text { pound-avoirdupois (lb avdp) } \\
\text { pound-avoirdupois } \mathrm{U}_{3} \mathrm{O}_{8}{ }^{\mathrm{b}} \\
\text { ton, short }(2,000 \mathrm{lb})\end{array}$ & $\begin{array}{l}\text { kilogram }(\mathrm{kg}) \\
\text { kilogram U } \\
\text { metric ton }(\mathrm{t})\end{array}$ & $\begin{array}{l}0.453592 \\
0.384647 \\
0.907185\end{array}$ \\
\hline
\end{tabular}

"An asterisk after the last digit indicates that the conversion factor is exact and that all subsequent digits are zero. All other conversion factors are rounded to six digits after the decimal.

'The factor of 1 pound $\mathrm{U}_{3} \mathrm{O}_{8}=0.848002$ pounds $\mathrm{U}$ was used in this conversion.

Source: Table D1 is patterned after Table 3, "Conversion Factors for SI Metric Units and U.S. Customary Units of Measurement," in S.M. Long and A.M. Orellana, "The Metric System," in Suggestions to Authors of the Reports of the United States Geological Survey, Sixth Edition, U.S. Government Printing Office (Washington, DC, 1978) pp. 192-196. 


\section{Forward Cost and Average Price Conversions}

The forward-cost categories of \$US80 through \$US130 per pound U shown on Table D3 to report uranium reserves quantities were converted from units of " $\$$ per pound $\mathrm{U}_{3} \mathrm{O}_{8}$ " to "\$ per kilogram U" by multiplying by the standard factor of 2.6 and rounding the results to the nearest multiple of \$US10.

\section{Selected Tables Converted to SI Metric Values}

Sixteen principal tables of data from the Uranium Industry Annual 1996 (UIA) converted to equivalent metric values are shown on the following pages. The crosswalk given below shows the correlation between the tables of metric values and their corresponding tables in U.S. customary units in the main body of the UIA.
Appendix D Table Number

\section{UIA Chapter and} Table Number

\begin{tabular}{|c|}
\hline 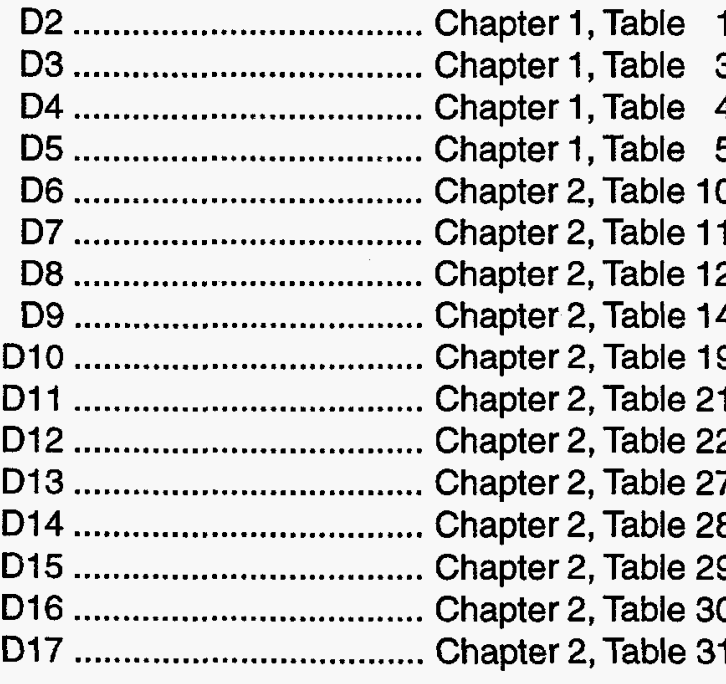 \\
\hline
\end{tabular}


Table D2. U.S. Uranium Land and Surface Drilling Activities, 1987-1996

\begin{tabular}{|c|c|c|c|c|c|c|c|c|c|c|c|}
\hline \multirow[b]{2}{*}{ Year } & \multicolumn{2}{|c|}{$\begin{array}{c}\text { Land } \\
\text { Exploration }\end{array}$} & \multicolumn{3}{|c|}{$\begin{array}{l}\text { Surface Drilling } \\
\text { Exploration }\end{array}$} & \multicolumn{3}{|c|}{$\begin{array}{l}\text { Surface Drilling } \\
\text { Development }\end{array}$} & \multicolumn{3}{|c|}{\begin{tabular}{|c|} 
Surface Drilling \\
Exploration and Development
\end{tabular}} \\
\hline & \begin{tabular}{|c|} 
Square \\
Meters \\
Acquired \\
during \\
Year \\
(millions)
\end{tabular} & \begin{tabular}{|c|} 
Square \\
Meters \\
Held at \\
End of \\
Year \\
(millions)
\end{tabular} & $\begin{array}{l}\text { Number } \\
\text { of Holes }\end{array}$ & $\begin{array}{c}\text { Meters } \\
\text { (thousand) }\end{array}$ & $\begin{array}{c}\text { Cost" } \\
\text { (thousand } \\
\text { dollars) }\end{array}$ & $\begin{array}{l}\text { Number } \\
\text { of Holes }\end{array}$ & $\begin{array}{c}\text { Meters } \\
\text { (thousand) }\end{array}$ & $\begin{array}{c}\text { Cost" } \\
\text { (thousand } \\
\text { dollars) }\end{array}$ & $\begin{array}{l}\text { Number } \\
\text { of Holes }\end{array}$ & $\begin{array}{c}\text { Meters } \\
\text { (thousand) }\end{array}$ & $\begin{array}{c}\text { Costa }^{a} \\
\text { (thousand } \\
\text { dollars) }\end{array}$ \\
\hline $1987 \ldots$ & 364 & 7,689 & 1,820 & 338 & 5,900 & 1,994 & 262 & 1,060 & 3,814 & 600 & 6,960 \\
\hline $1988 \ldots$. & 364 & 6,880 & 2,029 & 390 & 6,4 & 3,176 & 527 & 3 & 5,205 & 917 & 9,700 \\
\hline $1989 \ldots$. & 113 & 6,188 & 2,087 & 436 & 5,820 & 1,753 & 244 & 3,120 & 3,840 & 680 & 8,940 \\
\hline $1990 \ldots$. & 154 & 4,893 & 1,507 & 265 & 3,210 & 1,908 & 247 & 5,950 & 3,415 & 512 & 9,160 \\
\hline $1991 \ldots$ & 130 & 4,290 & 1,624 & 297 & 2,832 & 1,573 & 265 & 8,114 & 3,197 & 561 & 10,946 \\
\hline $1992 \ldots$ & 344 & 3,189 & 935 & 171 & 1,267 & 833 & 153 & 1,162 & 1,768 & 324 & 2,429 \\
\hline $1993 \ldots$ & 263 & 1,841 & 355 & 68 & 983 & 1,665 & 270 & 4,754 & 2,020 & 338 & 5,737 \\
\hline $1994 \ldots$ & 36 & 1,315 & 519 & 104 & 736 & 477 & 96 & 383 & 996 & 200 & 1,119 \\
\hline $1995 \ldots$ & 28 & 1,048 & 584 & 122 & 790 & 1,728 & 289 & 1,799 & 2,312 & 411 & 2,589 \\
\hline $1996 \ldots$ & 146 & 1,166 & 1,118 & 269 & 1,602 & 3,577 & 659 & 5,549 & 4,695 & 928 & 7,150 \\
\hline
\end{tabular}

"Costs for 1987 through 1990 were rounded to the nearest $\$ 10$ thousand.

Note: Totals may not equal sum of components because of independent rounding.

Sources: Energy Information Administration: 1987-1995-Uranium Industry Annual 1995 (May 1996). 1996-Form ElA-858, "Uranium Industry Annual Survey" (1996).

Table D3. Forward-Cost Uranium Reserves by Mining Method, 1996

\begin{tabular}{|c|c|c|c|c|c|c|}
\hline \multirow[b]{3}{*}{ Mining Method } & \multicolumn{6}{|c|}{ Forward-Cost Category } \\
\hline & \multicolumn{3}{|c|}{$\$ 80$ per kilogram } & \multicolumn{3}{|c|}{$\$ 130$ per kilogram } \\
\hline & $\begin{array}{c}\text { Ore } \\
\text { (million } \\
\text { metric tons) }\end{array}$ & $\underset{\text { (percent U) }}{\text { Grade" }}$ & $\begin{array}{l}\text { Uranium } \\
\text { (thousand } \\
\text { metric tons) }\end{array}$ & $\begin{array}{c}\text { Ore } \\
\text { (million } \\
\text { metric tons) }\end{array}$ & $\begin{array}{c}\text { Gradea } \\
(\text { percent } U)\end{array}$ & $\begin{array}{c}\text { Uranium } \\
\text { (thousand } \\
\text { metric tons) }\end{array}$ \\
\hline Underground ....................... & 23 & 0.232 & 53 & 130 & 0.138 & 179 \\
\hline 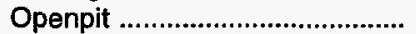 & 9 & 0.118 & 11 & 148 & 0.067 & 99 \\
\hline 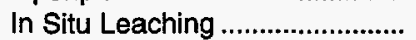 & 41 & 0.112 & 45 & 117 & 0.067 & 78 \\
\hline Other ${ }^{b}$ & $<1$ & 0.223 & $<1$ & 14 & 0.042 & 6 \\
\hline 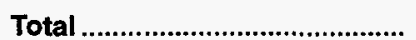 & 73 & 0.151 & 110 & 407 & 0.089 & 361 \\
\hline
\end{tabular}

aWeighted average percent $U$ per metric ton of ore.

bIncludes heap leach, mine water, and low grade stockplles.

Notes: Uranium reserves that could be recovered as a byproduct of phosphate and copper mining are not included in this table. Reserves values in forward-cost categories are cumulative: That is, the quantity at each level of forward-cost includes all reserves at the lower costs. Totals may not equal sum of components because of independent rounding.

Sources: Estimated by Energy Information Administration, Office of Coal, Nuclear, Electric and Alternate Fuels, based on industry conferences, U.S. Department of Energy, Grand Junction Projects Office data files, and Energy Information Administration, Form ElA-858, "Uranium Industry Annual Survey" (1996). 
Table D4. U.S. Uranium Mine Production and Number of Mines and Sources, 1987-1996

\begin{tabular}{|c|c|c|c|c|c|c|c|c|c|c|}
\hline Mining Method & 1987 & 1988 & 1989 & 1990 & 1991 & 1992 & 1993 & 1994 & 1995 & 1996 \\
\hline $\begin{array}{l}\text { Underground } \\
\text { (metric tons } U \text { ) }\end{array}$ & 1,900 & 2,100 & 2,000 & $W$ & W & $W$ & 0 & 0 & 0 & W \\
\hline $\begin{array}{l}\text { Openpit } \\
\text { (metric tons } U \text { ) }\end{array}$ & W & W & W & 724 & 972 & $w$ & 0 & 0 & 0 & 0 \\
\hline $\begin{array}{l}\text { In Situ Leaching } \\
\text { (metric tons U) }\end{array}$ & W & W & W & W & W & $w$ & W & 942 & 1,297 & 1,684 \\
\hline $\begin{array}{l}\text { Other }^{2} \\
\text { (metric tons U) }\end{array}$ & 400 & 1,600 & 1,700 & 1,537 & 1,021 & 379 & 789 & 30 & 60 & 125 \\
\hline $\begin{array}{l}\text { Total Mine Production } \\
\text { (metric tons } U)\end{array}$ & 2,300 & 3,700 & 3,700 & 2,260 & 1,993 & 379 & 789 & 972 & 1,357 & 1,810 \\
\hline 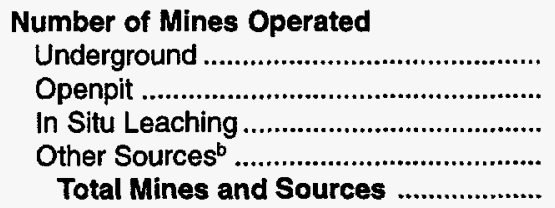 & $\begin{array}{r}19 \\
2 \\
15 \\
1 \\
37\end{array}$ & $\begin{array}{r}17 \\
4 \\
11 \\
0 \\
32\end{array}$ & $\begin{array}{r}19 \\
2 \\
9 \\
2 \\
32\end{array}$ & $\begin{array}{r}27 \\
2 \\
7 \\
3 \\
39\end{array}$ & $\begin{array}{r}6 \\
2 \\
6 \\
1 \\
15\end{array}$ & $\begin{array}{r}4 \\
1 \\
4 \\
8 \\
17\end{array}$ & $\begin{array}{r}0 \\
0 \\
5 \\
7 \\
12\end{array}$ & $\begin{array}{r}0 \\
0 \\
5 \\
7 \\
12\end{array}$ & $\begin{array}{r}0 \\
0 \\
5 \\
7 \\
12\end{array}$ & $\begin{array}{r}1 \\
0 \\
6 \\
6 \\
13\end{array}$ \\
\hline
\end{tabular}

"For 1987 through 1989, "Other" includes production from openpit, in situ leach, heap leach, mine water, and water-treatment plant solutions. Production quantities were rounded to the nearest 100 metric tons. For 1990 and 1991, "Other" includes production from underground, in situ leach, heap leach (1990), mine water, water treatment plant solutions (1990), and restoration. For 1992, "Other" includes production from underground, openpit, and in situ leach mines and uranium bearing water from mine workings, tailings ponds, and restoration. For 1993, the "Other" includes production from in situ leach mines and urainum bearing water from mine workings and restoration. For 1994 and 1995, "Other" includes production from uranium bearing water from mine workings and restoration. For 1996, "Other" includes production from an underground mine and uranium bearing water from mine workings and restoration.

'Other Sources includes, in various years, heap leach, mine water, mill site cleanup and mill tailings, well field restoration, and low-grade stockpiles as sources of uranium.

$W=$ Data withheld to avoid disclosure. The data are included in the total for "Other."

Notes: Totals may not equal sum of components because of independent rounding. Table does not include byproduct production and sources.

Sources: Energy Information Administration: 1987-1995-Uranium Industry Annnual 1995 (May 1996); 1996-Form EIA-858, "Uranium Industry Annual Survey" (1996). 
Table D5. U.S. Uranium Concentrate Processing Operations, 1987-1996

\begin{tabular}{|c|c|c|c|c|c|c|c|c|c|c|}
\hline Processing Operations & 1987 & 1988 & 1989 & 1990 & 1991 & 1992 & 1993 & 1994 & 1995 & 1996 \\
\hline $\begin{array}{l}\text { Ore Fed to Process } \\
\text { (thousand metric tons) }\end{array}$ & 1,307 & 1,101 & 1,120 & 655 & 580 & 232 & 0 & 0 & 151 & 40 \\
\hline 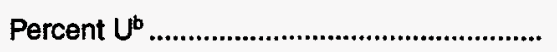 & 0.241 & 0.244 & 0.274 & 0.248 & 0.168 & 0.194 & - & - & 0.441 & 0.424 \\
\hline Contained $U$ (metric tons) & & & & & & & & & & \\
\hline $\begin{array}{l}\text { In Ore } \\
\text { Other Feed Materials }{ }^{c}\end{array}$ & $\begin{array}{r}3,150 \\
182\end{array}$ & $\begin{array}{r}2,692 \\
195\end{array}$ & $\begin{array}{r}3,068 \\
165\end{array}$ & $\begin{array}{r}1,626 \\
187\end{array}$ & $\begin{array}{r}973 \\
69\end{array}$ & $\begin{array}{r}451 \\
70\end{array}$ & $\begin{array}{r}0 \\
16\end{array}$ & $\begin{array}{r}0 \\
30\end{array}$ & $\begin{array}{r}669 \\
63\end{array}$ & $\begin{array}{l}171 \\
157\end{array}$ \\
\hline Total Mill Feed (metric tons U) ....................... & 3,333 & 2,887 & 3,233 & 1,812 & 1,042 & 520 & 16 & 30 & 732 & 328 \\
\hline $\begin{array}{l}\text { In-Process Inventory Change } \\
\text { (metric tons U) }\end{array}$ & -81 & 52 & -90 & -94 & -47 & -10 & 4 & 9 & 60 & -53 \\
\hline $\begin{array}{l}\text { Concentrate Produced at Mills } \\
\text { (metric tons U) }\end{array}$ & & & & & & & & & & \\
\hline 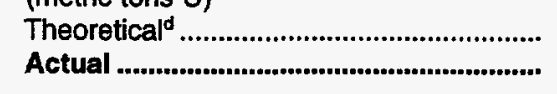 & $\begin{array}{l}3,413 \\
3,283\end{array}$ & $\begin{array}{l}2,834 \\
2,706\end{array}$ & $\begin{array}{l}3,323 \\
3,144\end{array}$ & $\begin{array}{l}1,906 \\
\mathbf{1 , 7 8 8}\end{array}$ & $\begin{array}{l}1,089 \\
1,003\end{array}$ & $\begin{array}{l}530 \\
523\end{array}$ & $\begin{array}{l}12 \\
12\end{array}$ & $\begin{array}{l}21 \\
18\end{array}$ & $\begin{array}{l}671 \\
621\end{array}$ & $\begin{array}{l}381 \\
331\end{array}$ \\
\hline Recovery as Percent of Total Mill Feed....... & 96.2 & 95.5 & 94.6 & 93.8 & 92.2 & 98.7 & - & - & 92.6 & 86.8 \\
\hline $\begin{array}{l}\text { Tailings and Unaccountable } \\
\text { (metric tons U) }\end{array}$ & 130 & 129 & 179 & 118 & 85 & 7 & 0 & 3 & 50 & 50 \\
\hline $\begin{array}{l}\text { Other Processing } \\
\text { (metric tons U) }\end{array}$ & 1,714 & 2,345 & 2,178 & 1,630 & 2,056 & 1,649 & 1,167 & 1,272 & 1,703 & 2,101 \\
\hline $\begin{array}{l}\text { Total Concentrate Production } \\
\text { (metric tons U) }\end{array}$ & 4,997 & 5,050 & 5,322 & 3,418 & 3,059 & 2,171 & 1,178 & 1,289 & 2,324 & 2,431 \\
\hline $\begin{array}{l}\text { Total Concentrate Shipped From Mills } \\
\text { and Plants } \\
\quad(\text { metric tons U) }\end{array}$ & 4,446 & 4,920 & 5,696 & 4,984 & 3,245 & 2,636 & 1,298 & 2,431 & 2,116 & 2,301 \\
\hline
\end{tabular}

"Uranium ore "fed to process" in any year can include: ore mined and shipped to a mill during the same year, ore that was mined during a prior year and later shipped from mine-site stockpiles, and/or ore obtained from drawdowns of stockpiles maintained at a mill site.

bWeighted average percent $U$ per metric ton of ore.

Includes for various years uranium from low-grade ore, mill cleanup, mine water, tailings water, and heap leaching, except as footnoted below.

${ }^{a}$ At 100-percent recovery. This equals total mill feed minus in-process inventory change.

$-\mathrm{U}_{3} \mathrm{O}_{8}$ concentrate production from in situ leaching and as a byproduct of other processing. The totals for 1987 through 1988 include $\mathrm{U}_{3} \mathrm{O}_{8}$ recovered from reclamation and mine water at some mills that did not report processing of uranium ore for those years.

--Not applicable.

Note: Totals may not equal sum of components because of independent rounding.

Sources: Energy information Administration: 1987-1995-Uranium Industry Annnual 1995 (May 1996); 1996-Form EIA-858, "Uranium Industry Annual Survey" (1996). 
Table D6. U.S. Utilities Contracted Uranium by Supplier, Transaction Type, and Delivery Year, 1994-1996

(Metric Tons U Equivalent; Dollars per Kilogram U Equivalent)

\begin{tabular}{|c|c|c|c|}
\hline Actual Deliveries & 1994 & 1995 & 1996 \\
\hline \multicolumn{4}{|l|}{ Received by U.S. Utilities from U.S. Producers: } \\
\hline Purchases & 2,093 & 2,034 & 2,218 \\
\hline 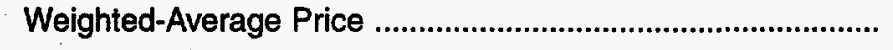 & 35.68 & 38.59 & 36.91 \\
\hline \multicolumn{4}{|l|}{ Received by U.S. Utilities from U.S. Brokers and Traders: } \\
\hline 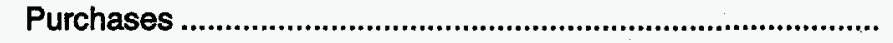 & 5,879 & 6,232 & 5,124 \\
\hline 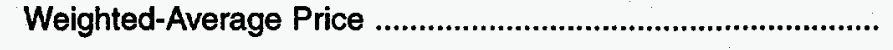 & 24.29 & 25.56 & 34.73 \\
\hline \multicolumn{4}{|l|}{ Received by U.S. Utilities from other U.S. Utilities: } \\
\hline Purchases & 0 & 0 & 0 \\
\hline 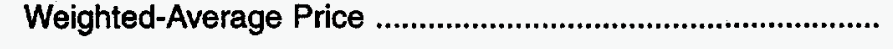 & - & - & - \\
\hline \multicolumn{4}{|l|}{ Received by U.S. Utilities from other U.S. suppliers: } \\
\hline Purchases & 420 & 216 & a725 \\
\hline 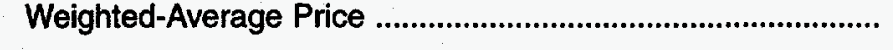 & 20.90 & 32.56 & 38.95 \\
\hline \multicolumn{4}{|l|}{ Received by U.S. Utilities from Foreign Suppliers: } \\
\hline 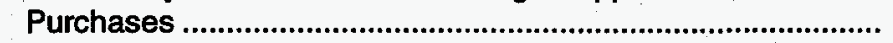 & 6,332 & 8,227 & 10,139 \\
\hline 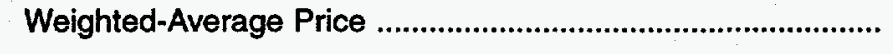 & 27.11 & 29.63 & 37.57 \\
\hline \multicolumn{4}{|l|}{ Total Received by U.S. Utilities: } \\
\hline 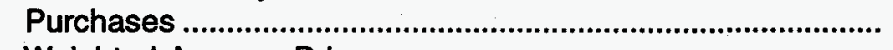 & 14,725 & 16,709 & a18,206 \\
\hline 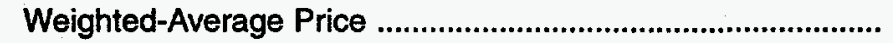 & 27.03 & 29.24 & 36.71 \\
\hline
\end{tabular}

-The quantity with a reported price was 435 metric tons $U$ equivalent from other U.S. suppliers and 17,916 metric tons $U$ equivalent for total received by U.S. utilities.

- Not applicable

Notes: "Other U.S. suppliers" are U.S. converters, enrichers, and fabricators. Totals may not equal sum of componentns because of independent rounding. Source: Energy Information Administration, Form ElA-858, "Uranium Industry Annual Survey" (1994-1996).

Table D7. U.S. Utilities Contracted Uranium by Transaction Type and Delivery Year, 1994-1996 (Metric Tons U Equivalent; Dollars per Kilogram U Equivalent)

\begin{tabular}{|c|c|c|c|}
\hline Actual Deliveries & 1994 & 1995 & 1996 \\
\hline $\begin{array}{l}\text { Received by U.S. Utilities of U.S.-Origin Uranium: } \\
\text { Purchases . } \\
\text { Weighted-Average Price }\end{array}$ & $\begin{array}{l}2,969 \\
31.39\end{array}$ & $\begin{array}{l}2,018 \\
36.93\end{array}$ & $\begin{array}{l}3,192 \\
38.01\end{array}$ \\
\hline 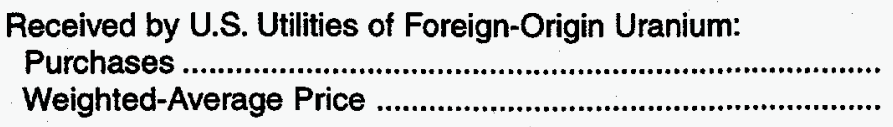 & $\begin{array}{r}11,756 \\
25.92\end{array}$ & $\begin{array}{r}14,692 \\
28.18\end{array}$ & $\begin{array}{r}15,014 \\
36.45\end{array}$ \\
\hline 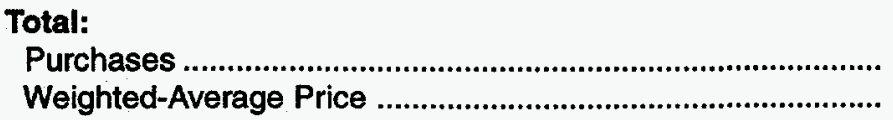 & $\begin{array}{r}14,725 \\
27.03\end{array}$ & $\begin{array}{r}16,709 \\
29.24\end{array}$ & $\begin{array}{r}18,206 \\
36.71\end{array}$ \\
\hline
\end{tabular}

The quantity with a reported price was 2,919 metric tons $U$ equivalent of U.S.-origin uranium, 14,997 metric tons $U$ equivalent of foreign-origin uranium, and 17,916 metric tons $U$ equivalent for total received by U.S. utilities.

Note: Totals may not equal sum of components because of independent rounding.

Source: Energy Information Administration, Form ElA-858, "Uranium Industry Annual Survey" (1994-1996). 
Table D8. U.S. Utilities Purchases of Uranium by Origin Country and Delivery Year, 1994-1996 (Metric Tons U Equivalent; Dollars per Kilogram U Equivalent)

\begin{tabular}{|c|c|c|c|c|c|c|}
\hline \multirow[b]{2}{*}{ Origin Country } & \multicolumn{2}{|c|}{ Actual Deliveries in 1994} & \multicolumn{2}{|c|}{ Actual Deliveries in 1995} & \multicolumn{2}{|c|}{ Actual Deliveries in 1996} \\
\hline & Purchases & $\begin{array}{c}\text { Weighted- } \\
\text { Average Price }\end{array}$ & Purchases & $\begin{array}{c}\text { Weighted- } \\
\text { Average Price }\end{array}$ & Purchases & $\begin{array}{c}\text { Weighted- } \\
\text { Average Price }\end{array}$ \\
\hline \multicolumn{7}{|l|}{ All Purchases: } \\
\hline 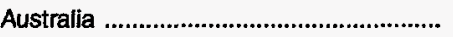 & 1,082 & 25.70 & 1,711 & 28.54 & 1,753 & 38.10 \\
\hline 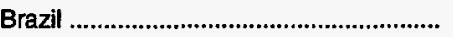 & W & W & 0 & - & 0 & - \\
\hline 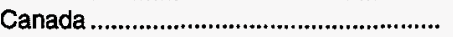 & 5,621 & 27.28 & 6,462 & 30.74 & 7,344 & 37.30 \\
\hline 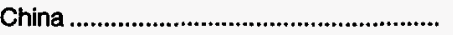 & 652 & 24.85 & 113 & 29.87 & 143 & 39.79 \\
\hline France & $W$ & $W$ & $W$ & $\mathbf{W}$ & $\mathbf{W}$ & $W$ \\
\hline Gabon & $w$ & $W$ & $W$ & W & W & w \\
\hline Germany & $w$ & $W$ & $w$ & W & 372 & 35.21 \\
\hline 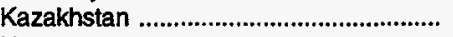 & 1,068 & 23.25 & 1,191 & 23.36 & 575 & 38.04 \\
\hline 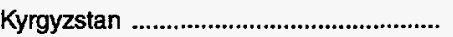 & W & $w$ & W & W & 0 & - \\
\hline 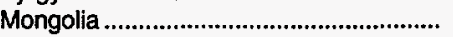 & W & W & $W$ & $W$ & $W$ & $W$ \\
\hline 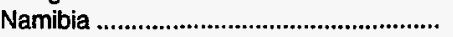 & 306 & 25.38 & 204 & 25.68 & $w$ & W \\
\hline 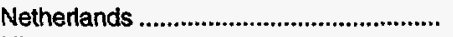 & 0 & - & W & $W$ & $w$ & W \\
\hline 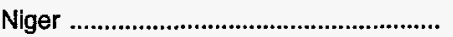 & 0 & 一 & $W$ & $W$ & $w$ & W \\
\hline 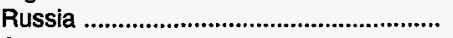 & 684 & 22.90 & 2,116 & 24.57 & 2,090 & 32.99 \\
\hline 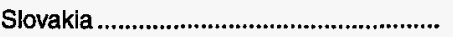 & 0 & - & 0 & - & W & W \\
\hline 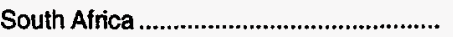 & 425 & 25.07 & 385 & 32.68 & 643 & 34.75 \\
\hline Spain & 0 & - & W & W & 0 & - \\
\hline 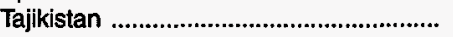 & W & $W$ & W & W & $W$ & $W$ \\
\hline 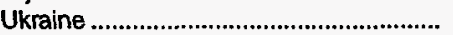 & $W$ & $W$ & $W$ & W & 381 & 35.33 \\
\hline United Kingdom & W & $w$ & W & W & 0 & - \\
\hline 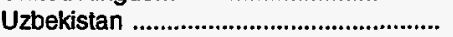 & 1,365 & 21.70 & 1,498 & 22.37 & 1,332 & 35.11 \\
\hline 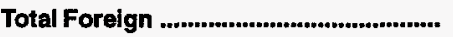 & 11,756 & 25.92 & 14,692 & 28.18 & 15,014 & 36.45 \\
\hline 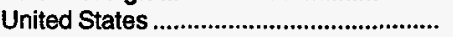 & 2,969 & 31.39 & 2,018 & 36.93 & 3,192 & 38.01 \\
\hline Total Purchases .......................................... & 14,725 & 27.03 & 16,709 & 29.24 & 18,206 & 36.71 \\
\hline \multicolumn{7}{|l|}{ Domestic Purchases (Non-Imports): } \\
\hline 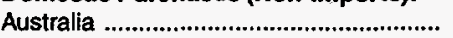 & 499 & 24.75 & 897 & 27.66 & 310 & 40.21 \\
\hline 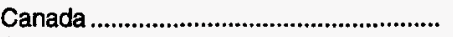 & 1,778 & 26.14 & 895 & 34.29 & 1,283 & 35.07 \\
\hline China & 622 & 24.49 & W & W & 143 & 39.79 . \\
\hline 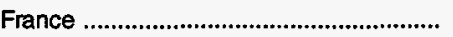 & $W$ & $w$ & 0 & 一 & $\mathbf{W}$ & W \\
\hline Gabon & $W$ & $W$ & 0 & - & W & $W$ \\
\hline Germany & W & $w$ & W & $w$ & $W$ & $\mathbf{W}$ \\
\hline 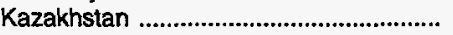 & 375 & 23.79 & 677 & 21.57 & 98 & 37.74 \\
\hline Kyrgyzstan & $\mathbf{w}$ & $W$ & $w$ & W & 0 & - \\
\hline 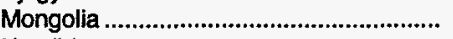 & W & $w$ & $w$ & 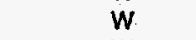 & $w$ & $W$ \\
\hline Namibia & 163 & 24.07 & $W$ & W & W & $W$ \\
\hline 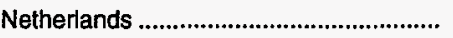 & 0 & - & 0 & - & W & W \\
\hline Niger & 0 & - & 0 & - & $W$ & W \\
\hline Russia & 293 & 24.01 & 1,452 & 24.61 & 1,673 & 33.29 \\
\hline 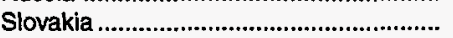 & 0 & - & 0 & - & W & W \\
\hline 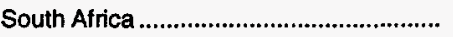 & 425 & 25.07 & W & W & 345 & 33.00 \\
\hline 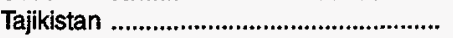 & $W$ & $w$ & W & $w$ & 0 & - \\
\hline 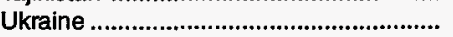 & 0 & - & $w$ & W & 381 & 35.33 \\
\hline 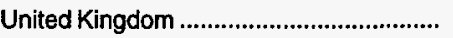 & $W$ & W & $W$ & W & 0 & - \\
\hline 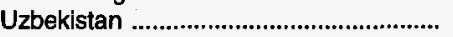 & 1,240 & 20.67 & $w$ & $\mathbf{W}$ & W & W \\
\hline 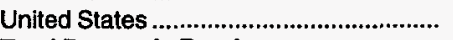 & 2,969 & 31.39 & 2,018 & 36.93 & 3,192 & 38.01 \\
\hline Total Domestic Purchases ...................... & 8,749 & 26.79 & 8,578 & 28.89 & 9,100 & 35.91 \\
\hline \multicolumn{7}{|l|}{ Foreign Purchases (Imports): } \\
\hline 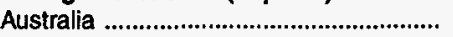 & 583 & 26.51 & 814 & 29.50 & 1,443 & 37.65 \\
\hline 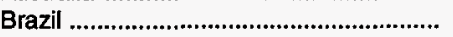 & W & $\mathbf{W}$ & 0 & - & 0 & - \\
\hline 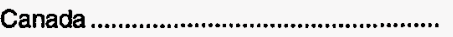 & 3,843 & 27.80 & 5,567 & 30.17 & 6,061 & 37.76 \\
\hline 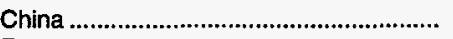 & 31 & 32.32 & W & $w$ & 0 & - \\
\hline 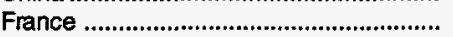 & 0 & - & w & $\mathbf{W}$ & 0 & - \\
\hline Gabon & $w$ & W & $w$ & $w$ & W & $w$ \\
\hline Germany & 0 & - & 0 & - & W & $w$ \\
\hline 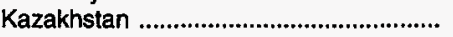 & 693 & 22.96 & 514 & 25.73 & 477 & 38.11 \\
\hline 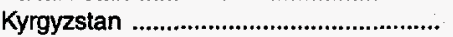 & W & W & 0 & - & 0 & 一 \\
\hline 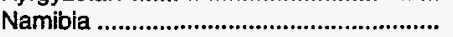 & 143 & 26.88 & $\mathbf{W}$ & W & 0 & - \\
\hline 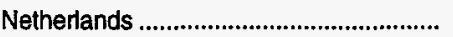 & 0 & - & W & W & 0 & - \\
\hline 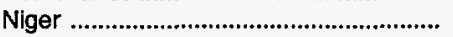 & 0 & 一 & $\mathbf{W}$ & W & 0 & - \\
\hline Russia & 391 & 22.07 & 663 & 24.49 & 417 & 31.77 \\
\hline South Africa & 0 & - & w & $W$ & 298 & 36.77 \\
\hline Spain & 0 & - & W & W & 0 & - \\
\hline 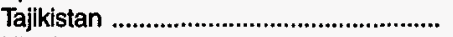 & 0 & - & $w$ & W & $\mathbf{W}$ & W \\
\hline 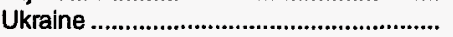 & $w$ & w & 0 & - & 0 & 一 \\
\hline Uzbekistan & 126 & 31.86 & $w$ & $w$ & $\mathbf{w}$ & $\mathbf{w}$ \\
\hline Total Foreign Purchase ............................ & 5,976 & 27.38 & 8,131 & 29.61 & 9,107 & 37.47 \\
\hline
\end{tabular}

W=Data withheld to avoid disclosure. $\cdots=$ Not applicable.

Note: Totals may not equal sum of components because of independent rounding.

Source: Energy Information Administration, Form ElA-858, "Uranium Industry Annual Survey" (1994-1996). 
Table D9. Average Price and Quantity for Purchases of Uranium by U.S. Utilities by Pricing Mechanisms and Delivery Year, 1994-1996

(Dollars per Kilogram U Equivalent; Metric Tons U Equivalent)

\begin{tabular}{|c|c|c|c|c|c|c|c|c|c|}
\hline \multirow[b]{2}{*}{ Pricing Mechanisms } & \multicolumn{3}{|c|}{ Domestic Purchases } & \multicolumn{3}{|c|}{ Foreign Purchases } & \multicolumn{3}{|c|}{ Total Purchases } \\
\hline & 1994 & 1995 & 1996 & 1994 & 1995 & 1996 & 1994 & 1995 & 1996 \\
\hline 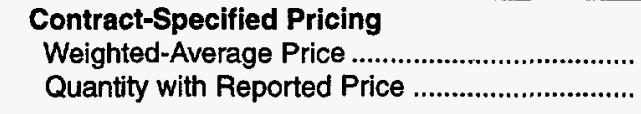 & $\begin{array}{l}27.76 \\
4,290\end{array}$ & $\begin{array}{l}27.50 \\
6,564\end{array}$ & $\begin{array}{l}34.83 \\
6,407\end{array}$ & $\begin{array}{r}30.98 \\
957\end{array}$ & $\begin{array}{l}69 \\
48\end{array}$ & $\begin{array}{l}33 \\
103\end{array}$ & $\begin{array}{l}28.34 \\
5,248\end{array}$ & $\begin{array}{l}29.02 \\
8,712\end{array}$ & $\begin{array}{l}35.23 \\
8,710\end{array}$ \\
\hline 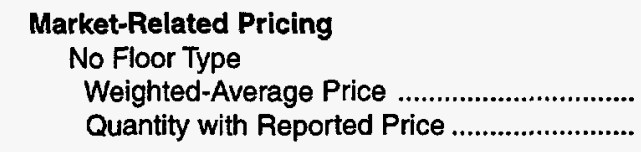 & $\begin{array}{l}25.38 \\
2,724\end{array}$ & $\begin{array}{r}26.48 \\
815\end{array}$ & $\begin{array}{r}35.52 \\
849\end{array}$ & $\begin{array}{l}23.94 \\
3,181\end{array}$ & & $\begin{array}{l}35 \\
81\end{array}$ & $\begin{array}{l}24.60 \\
5,905\end{array}$ & $\begin{array}{l}86 \\
99\end{array}$ & $\begin{array}{l}37.56 \\
3,030\end{array}$ \\
\hline $\begin{array}{l}\text { Floor Type } \\
\text { Weighted-Average Price .............................. } \\
\text { Quantity with Reported Price ....................... }\end{array}$ & $\begin{array}{r}52.07 \\
233\end{array}$ & $\begin{array}{r}46.42 \\
263\end{array}$ & $\begin{array}{r}41.93 \\
865\end{array}$ & & & & & & $\begin{array}{l}38.78 \\
4,622\end{array}$ \\
\hline 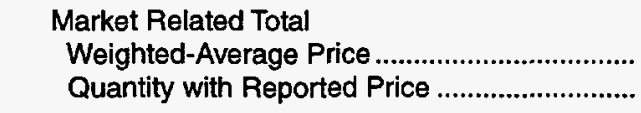 & $\begin{array}{l}27.48 \\
2,958\end{array}$ & $\begin{array}{l}31.34 \\
1,078\end{array}$ & $\begin{array}{l}38.76 \\
1,714\end{array}$ & & & $\begin{array}{l}16 \\
37\end{array}$ & & $\begin{array}{l}28.78 \\
5,912\end{array}$ & $\begin{array}{l}38.30 \\
7,651\end{array}$ \\
\hline 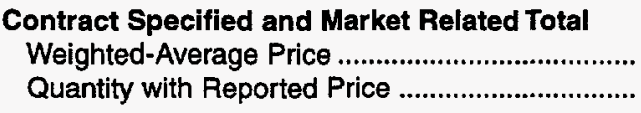 & $\begin{array}{l}27.64 \\
7,248\end{array}$ & $\begin{array}{l}28.04 \\
7,642\end{array}$ & $\begin{array}{l}35.66 \\
\mathbf{8}, 121\end{array}$ & $\begin{array}{l}26.93 \\
5,638\end{array}$ & & $\begin{array}{l}37.65 \\
8,240\end{array}$ & $\begin{array}{r}27.33 \\
12,886\end{array}$ & $\begin{array}{r}28.92 \\
14,624\end{array}$ & $\begin{array}{r}36.66 \\
16,362\end{array}$ \\
\hline 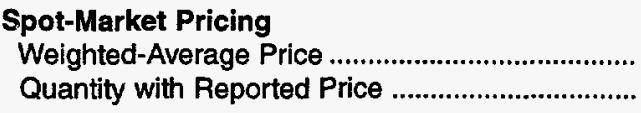 & $\begin{array}{r}24.37 \\
275\end{array}$ & $\begin{array}{r}23.59 \\
288\end{array}$ & $\begin{array}{r}38.74 \\
650\end{array}$ & $\begin{array}{r}0.00 \\
0\end{array}$ & $\begin{array}{r}26.68 \\
656\end{array}$ & $\begin{array}{r}37.08 \\
549\end{array}$ & $\begin{array}{r}24.37 \\
275\end{array}$ & $\begin{array}{r}25.74 \\
944\end{array}$ & $\begin{array}{l}37.98 \\
1,199\end{array}$ \\
\hline 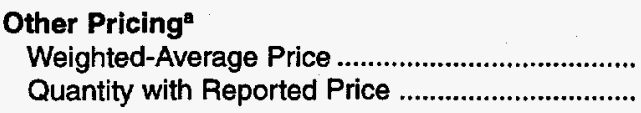 & $\begin{array}{l}22.25 \\
1,226\end{array}$ & $\begin{array}{r}41.27 \\
649\end{array}$ & $\begin{array}{r}41.28 \\
38\end{array}$ & $\begin{array}{r}34.91 \\
338\end{array}$ & $\begin{array}{r}29.47 \\
492\end{array}$ & $\begin{array}{r}33.52 \\
317\end{array}$ & $\begin{array}{l}24.99 \\
1,564\end{array}$ & $\begin{array}{l}36.18 \\
1,141\end{array}$ & $\begin{array}{r}34.36 \\
356\end{array}$ \\
\hline 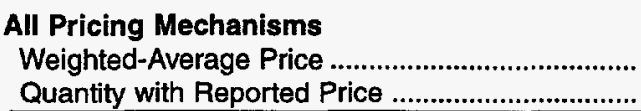 & $\begin{array}{l}26.79 \\
8,749\end{array}$ & $\begin{array}{l}28.89 \\
8,578\end{array}$ & $\begin{array}{l}35.91 \\
\mathbf{8 , 8 1 0}\end{array}$ & $\begin{array}{l}27.38 \\
5,976\end{array}$ & $\begin{array}{l}29.61 \\
8,131\end{array}$ & $\begin{array}{l}37.47 \\
9,107\end{array}$ & $\begin{array}{r}27.03 \\
14,725\end{array}$ & $\begin{array}{r}29.24 \\
16,709\end{array}$ & $\begin{array}{r}36.71 \\
17,916\end{array}$ \\
\hline
\end{tabular}

"Category used to report pricing mechanisms that are different from the other categories.

--=Not applicable.

Note: Totals may not equal sum of componentns because of independent rounding.

Source: Energy Information Administration, Form ElA-858, "Uranium Industry Annual Survey" (1994-1996).

Table D10. U.S. Utilities Contracted Purchases of Uranium from Suppliers, in Effect at the End of 1996, by Delivery Year, 1997-2006 (Metric Tons U Equivalent)

\begin{tabular}{|c|c|c|c|c|c|c|}
\hline \multirow[b]{2}{*}{ Year of Delivery } & \multicolumn{2}{|c|}{$\begin{array}{c}\text { Purchases from U.S. } \\
\text { Suppliers }\end{array}$} & \multicolumn{2}{|c|}{$\begin{array}{c}\text { Purchases from Foreign } \\
\text { Suppliers }\end{array}$} & \multicolumn{2}{|c|}{$\begin{array}{l}\text { Purchases from All } \\
\text { Suppliers }\end{array}$} \\
\hline & $\begin{array}{c}\text { Firm } \\
\text { Deliveries }\end{array}$ & $\begin{array}{l}\text { Optional } \\
\text { Deliveries }\end{array}$ & $\begin{array}{c}\text { Firm } \\
\text { Deliveries }\end{array}$ & $\begin{array}{l}\text { Optional } \\
\text { Deliveries }\end{array}$ & $\begin{array}{c}\text { Firm } \\
\text { Deliveries }\end{array}$ & $\begin{array}{l}\text { Optional } \\
\text { Deliveries }\end{array}$ \\
\hline $\begin{array}{l}1997 \\
1998 \\
1999 \\
2000 \\
2001 \\
2002\end{array}$ & $\begin{array}{r}5,751 \\
4,988 \\
3,856 \\
3,589 \\
2,303 \\
1,601 \\
601 \\
564 \\
190 \\
0\end{array}$ & $\begin{array}{r}323 \\
722 \\
617 \\
1,113 \\
352 \\
688 \\
424 \\
702 \\
328 \\
289\end{array}$ & $\begin{array}{r}8,055 \\
7,406 \\
5,599 \\
5,582 \\
2,946 \\
2,113 \\
789 \\
373 \\
102 \\
0\end{array}$ & $\begin{array}{r}1,269 \\
1,694 \\
1,517 \\
842 \\
1,043 \\
895 \\
835 \\
789 \\
-975 \\
308\end{array}$ & $\begin{array}{r}13,805 \\
12,394 \\
9,455 \\
9,171 \\
5,249 \\
3,714 \\
1,389 \\
938 \\
292 \\
0\end{array}$ & $\begin{array}{r}1,591 \\
2,416 \\
2,133 \\
1,955 \\
1,395 \\
1,583 \\
1,259 \\
1,491 \\
1,302 \\
597\end{array}$ \\
\hline 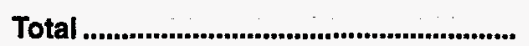 & 23,443 & 5,557 & 32,965 & 10,165 & 56,408 & 15,722 \\
\hline
\end{tabular}

Note: Totals may not equal sum of components because of independent rounding.

Source: Energy Information Administration, Form EIA-858, "Uranium Industry Annual Survey" (1996). 
Table D11. Anticipated Uranium Market Requirements of U.S. Utilities, 1997-2006, as of December 31, 1996 (Metric Tons U Equivalent)

\begin{tabular}{|c|c|c|c|c|}
\hline Year & $\begin{array}{l}\text { Quantity of Uranium Under } \\
\text { Purchase Contracts }\end{array}$ & $\begin{array}{c}\text { Unfilled } \\
\text { Requirements }\end{array}$ & $\begin{array}{c}\text { Anticipated Market } \\
\text { Requirements }\end{array}$ & $\begin{array}{c}\text { Enrichment Feed } \\
\text { Deliveries }\end{array}$ \\
\hline 1997 & 15,397 & 594 & 15,991 & 15,878 \\
\hline 1998 & 14,810 & 3,226 & 18,036 & 19,126 \\
\hline 1999 & 11,589 & 5,285 & 16,874 & 16,324 \\
\hline 2000 & 11,126 & 7,878 & 19,003 & 19,283 \\
\hline $2001 \ldots . . . . . . . . . .$. & 6,644 & 11,670 & 18,314 & 15,378 \\
\hline $2002 \ldots \ldots \ldots \ldots . .$. & 5,297 & 14,378 & 19,675 & 15,165 \\
\hline $2003 \ldots \ldots \ldots . . . . . .$. & 2,648 & 17,526 & 20,174 & 13,643 \\
\hline 2004 & 2,429 & 19,356 & 21,784 & 14,802 \\
\hline $2005 \ldots \ldots \ldots . . . . . . . .$. & 1,595 & 18,452 & 20,046 & 12,540 \\
\hline 2006 & 597 & 19,405 & 20,002 & 13,241 \\
\hline Total ............... & 72,131 & 117,770 & 189,901 & 155,379 \\
\hline
\end{tabular}

Note: Totals may not equal sum of components because of independent rounding.

Source: Energy Information Administration, Form EIA-858, "Uranium Industry Annual Survey" (1996).

Table D12. U.S. Utilities Deliveries of Uranium Feed by Enrichment Country and Delivery Year, 1994-1996

(Metric Tons U Equivalent)

\begin{tabular}{|c|c|c|c|c|c|c|c|c|c|}
\hline \multirow[b]{2}{*}{$\begin{array}{l}\text { Enrichment Plant } \\
\text { Location }\end{array}$} & \multicolumn{3}{|c|}{ Actual Deliveries in 1994} & \multicolumn{3}{|c|}{ Actual Deliveries in 1995} & \multicolumn{3}{|c|}{ Actual Deliveries in 1996} \\
\hline & $\begin{array}{l}\text { U.S.- } \\
\text { Origin }\end{array}$ & $\begin{array}{c}\text { Foreign- } \\
\text { Origin } \\
\end{array}$ & Total & $\begin{array}{l}\text { U.S.- } \\
\text { Origin }\end{array}$ & $\begin{array}{c}\text { Foreign- } \\
\text { Origin } \\
\end{array}$ & Total & $\begin{array}{l}\text { U.S.- } \\
\text { Origin }\end{array}$ & $\begin{array}{c}\text { Foreign- } \\
\text { Origin } \\
\end{array}$ & Total \\
\hline China ........ & W & w & W & 0 & 0 & 0 & 0 & 0 & 0 \\
\hline France..................... & W & w & 427 & w & w & $\mathrm{R} 1,847$ & 145 & 2,318 & 2,463 \\
\hline 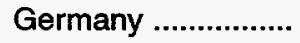 & 0 & 0 & 0 & w & W & 335 & W & w & W \\
\hline Netherlands ............. & 0 & 389 & 389 & w & w & 366 & $w$ & W & W \\
\hline Russia ........................... & W & w & 517 & 322 & 721 & 1,043 & 95 & 594 & 689 \\
\hline South Africa ............. & 0 & 0 & 0 & 0 & 0 & 0 & 0 & 0 & 0 \\
\hline United Kingdom ..... & 0 & w & W & 0 & 407 & 407 & $w$ & w & 230 \\
\hline Foreign Total .......... & 20 & 1,561 & 1,581 & 535 & 3,463 & 3,998 & 269 & 3,742 & 4,011 \\
\hline United States .......... & 3,258 & 9,627 & 12,885 & 2,995 & 10,045 & 13,040 & 3,195 & 11,672 & 14,867 \\
\hline Total ........................... & 3,278 & 11,188 & 14,466 & 3,530 & 13,508 & 17,038 & 3,464 & 15,414 & 18,878 \\
\hline
\end{tabular}

$W=$ Data withheld to avoid disclosure. $R=$ Revised data.

Note: Totals may not equal sum of components because of independent rounding.

Sources: Energy Information Administration, Form ElA-858, "Uranium Industry Annual Survey" (1994-1996).

Table D13. Uranium in Fuel Assemblies Loaded into U.S. Commercial Nuclear Reactors by Year, 1994-1996 (Metric Tons U Equivalent)

\begin{tabular}{|c|c|c|c|}
\hline Origin of Uranium & 1994 & 1995 & $1996^{P}$ \\
\hline 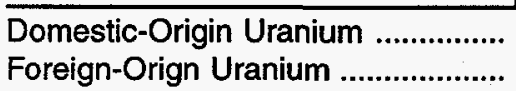 & $\begin{array}{r}3,578 \\
11,962\end{array}$ & $\begin{array}{r}4,287 \\
15,375\end{array}$ & $\begin{array}{r}3,354 \\
14,132\end{array}$ \\
\hline Total .................................................... & 15,540 & 19,662 & 17,486 \\
\hline
\end{tabular}

P = Preliminary data. Final 1995 fuel assembly data reported in the 1996 survey.

Notes: Includes only unirradiated uranium in new fuel assemblies loaded into reactors during the year. Does not include uranium removed from reactors that subsequently will be reloaded. Totals may not eaqual sum of components because of independent rounding.

Source: Energy Information Administration, Form ElA-858, "Uranlum Industry Annual Survey" (1995-1996). 
Table D14. Imports of Uranium by U.S. Suppliers, U.S. Utilities and Delivery Year, 1994-1996 (Metric Tons U Equivalent; Dollars per Kilograms U Equivalent)

\begin{tabular}{|c|c|c|c|}
\hline Actual Deliveries & 1994 & 1995 & 1996 \\
\hline $\begin{array}{l}\text { U.S. Suppliers: } \\
\text { Foreign Purchases (Imports) } \\
\text { Weighted-Average Price }\end{array}$ & $\begin{array}{l}8,109 \\
20.23\end{array}$ & $\begin{array}{l}7,755 \\
23.29\end{array}$ & $\begin{array}{l}8,365 \\
30.62\end{array}$ \\
\hline 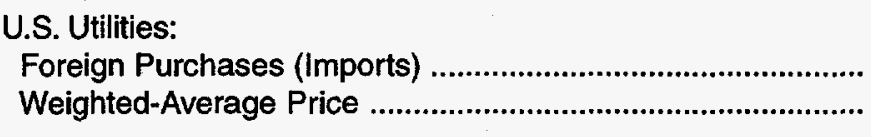 & $\begin{array}{l}5,976 \\
27.38\end{array}$ & $\begin{array}{l}8,131 \\
29.61\end{array}$ & $\begin{array}{l}9,107 \\
37.47\end{array}$ \\
\hline $\begin{array}{l}\text { U.S. Suppliers and U.S. Utilities: } \\
\text { Foreign Purchases (Imports) } \\
\text { Weighted-Average Price }\end{array}$ & $\begin{array}{r}14,085 \\
23.27\end{array}$ & $\begin{array}{r}15,886 \\
26.52\end{array}$ & $\begin{array}{r}17,471 \\
34.19\end{array}$ \\
\hline
\end{tabular}

Note: Totals may not equal sum of components because of independent rounding.

Source: Energy Information Administration, Form ElA-858, "Uranium Industry Annual Survey" (1994-1996).

Table D15. U.S. Brokers and Traders Purchases of Uranium by Material Origin, Supplier, and Delivery Year, 1994-1996

(Metric Tons U Equivalent; Dollars per Kilogram U Equivalent)

\begin{tabular}{|c|c|c|c|}
\hline Actual Deliveries & 1994 & 1995 & 1996 \\
\hline 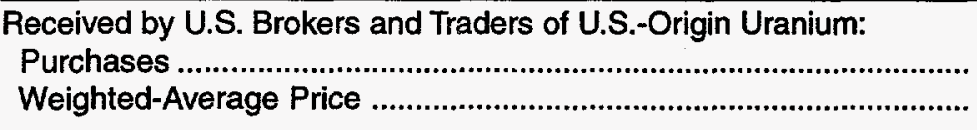 & $\begin{array}{l}1,843 \\
25.35\end{array}$ & $\begin{array}{l}1,291 \\
29.91\end{array}$ & $\begin{array}{l}1,817 \\
36.15\end{array}$ \\
\hline 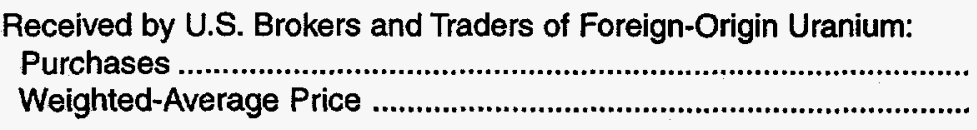 & $\begin{array}{r}10,005 \\
20.86\end{array}$ & $\begin{array}{l}7,536 \\
23.91\end{array}$ & $\begin{array}{l}7,896 \\
32.02\end{array}$ \\
\hline 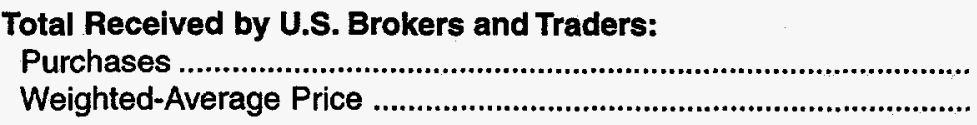 & $\begin{array}{r}11,848 \\
21.56\end{array}$ & $\begin{array}{l}8,827 \\
24.79\end{array}$ & $\begin{array}{l}9,714 \\
32.79\end{array}$ \\
\hline 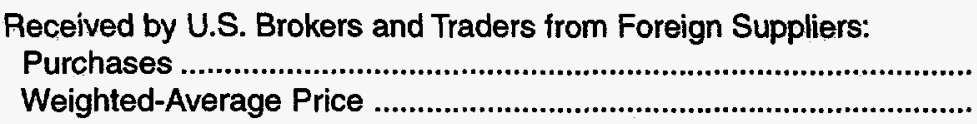 & $\begin{array}{l}8,588 \\
20.46\end{array}$ & $\begin{array}{l}7,043 \\
23.46\end{array}$ & $\begin{array}{l}6,853 \\
30.62\end{array}$ \\
\hline
\end{tabular}

Note: Totals may not equal sum of components because of independent rounding.

Source: Energy Information Administration, Form ElA-858, "Uranium Industry Annual Survey" (1994-1996). 
Table D16. Uranium Exports to Foreign Suppliers and Utilities by Origin and Delivery Year, 1994-1996

(Metric Tons U Equivalent; Dollars per Kilogram U Equivalent)

\begin{tabular}{|c|c|c|c|}
\hline Actual Deliveries to Foreign Suppliers and Utilities & 1994 & 1995 & 1996 \\
\hline \multicolumn{4}{|l|}{ U.S.-Origin Uranium: } \\
\hline 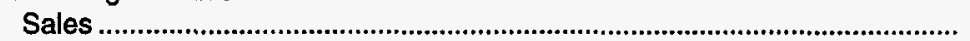 & 2,285 & 1,813 & 1,909 \\
\hline Weighted-Average Price & 47.86 & 45.07 & 44.76 \\
\hline \multicolumn{4}{|l|}{ Foreign-Origin Uranium: } \\
\hline 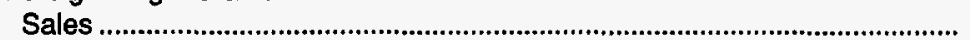 & 4,538 & 1,971 & 2,516 \\
\hline Weighted-Average Price & 20.24 & 25.84 & 30.98 \\
\hline \multicolumn{4}{|l|}{ Total Exports: } \\
\hline 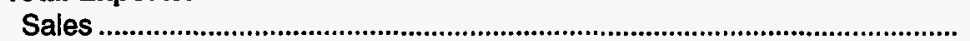 & 6,824 & 3,783 & 4,425 \\
\hline Weighted-Average Price & 29.49 & 35.06 & 36.92 \\
\hline \multicolumn{4}{|l|}{ Exports by U.S. Producers, U.S. Utilities, and Other U.S. Suppliers: } \\
\hline 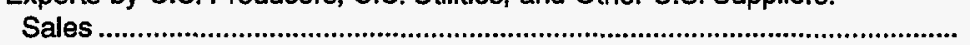 & 1,896 & 1,670 & 2,131 \\
\hline 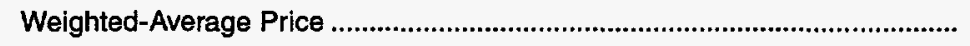 & 52.23 & 47.08 & 40.80 \\
\hline \multicolumn{4}{|l|}{ Exports by U.S. Brokers and Traders: } \\
\hline 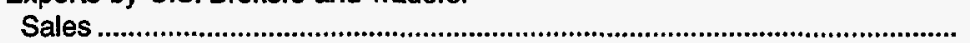 & 4,927 & 2,113 & 2,294 \\
\hline Weighted-Average Price & 20.73 & 25.55 & 33.32 \\
\hline
\end{tabular}

Notes: "Other U.S. Suppliers" are U.S. converters, enrichers, and fabricators. Totals may not equal sum of components because of independent rounding. Source: Energy Information Administration, Form ElA-858, "Uranium Industry Annual Survey" (1994-1996).

Table D17. Inventories of Natural and Enriched Uranium as of End of Year, 1994-1996 (Metric Tons U Equivalent)

\begin{tabular}{|c|c|c|c|}
\hline \multirow[b]{2}{*}{ Type of Uranium Inventory } & \multicolumn{3}{|c|}{ Inventories at the End of the Year } \\
\hline & 1994 & 1995 & $1996^{P}$ \\
\hline $\begin{array}{l}\text { U.S. Utility Inventories } \\
\text { Natural Uranium } \\
\text { Enriched Uranium }\end{array}$ & $\begin{array}{r}25,160 \\
16,316 \\
8,844\end{array}$ & $\begin{array}{r}\text { R22,590 } \\
\text { R15,858 } \\
\text { R6,733 }\end{array}$ & $\begin{array}{r}25,964 \\
16,238 \\
9,726\end{array}$ \\
\hline $\begin{array}{l}\text { U.S. Supplier Inventories } \\
\text { Natural Uranium } \\
\text { Enriched Uranium }\end{array}$ & $\begin{array}{l}8,258 \\
6,698 \\
1,560\end{array}$ & $\begin{array}{r}\text { R5,285 } \\
\text { R5,084 } \\
\text { R201 }\end{array}$ & $\begin{array}{r}5,265 \\
4,989 \\
276\end{array}$ \\
\hline 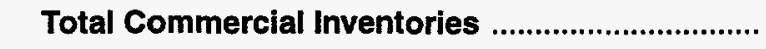 & 33,418 & $\mathbf{R 2 7 , 8 7 5}$ & 31,229 \\
\hline $\begin{array}{l}\text { DOE-Owned and USEC-Held Inventories } \\
\text { Natural Uranium } \\
\text { Enriched Uranium }\end{array}$ & $\begin{array}{l}32,776 \\
21,993 \\
10,783\end{array}$ & $\begin{array}{r}\text { R42,618 } \\
\text { R31,536 } \\
11,081\end{array}$ & $\begin{array}{r}41,422 \\
31,698 \\
9,724\end{array}$ \\
\hline
\end{tabular}

ancludes amounts reported as inventories of $\mathrm{UF}_{6}$ at Enrichment Suppliers.

DAmounts reported as inventories by U.S. Department of Energy (DOE) and the United States Enrichment Corporation (USEC).

$P=$ Preliminary data. $R=$ Revised data. Final 1995 inventory data reported in the 1996 survey

Note: Totals may not equal sum of components because of independent rounding.

Source: Energy Information Administration, Form EIA-858, "Uranium Industry Annual Survey" (1995-1996). 
Glossary 


\section{Glossary}

Contract-specified price: The delivery price determined when a contract is signed. It can be a fixed price or a base price escalated according to a given formula.

Conventional mill (uranium): A facility engineered and built principally for processing of uraniferous ore materials mined from the earth and the recovery, by chemical treatment in the mill's circuits, of uranium and/or other valued coproduct components from the processed ore.

Cost model for undiscovered resources: A computerized algorithm that uses the uranium endowment estimated for a given geological area and selected industry economic indexes to develop random variables that describe the undiscovered resources ultimately expected to be discovered in that area at chosen forward-cost categories.

Cutoff grade: The lowest grade, in percent $\mathrm{U}_{3} \mathrm{O}_{8}$, of uranium ore at a minimum specified thickness that can be mined at specified cost.

Development drilling: Drilling done to determine more precisely size, grade, and configuration of an ore deposit subsequent to the time the determination is made that the deposit can be commercially developed.

Domestic: Domestic means within the 50 States, District of Columbia, Puerto Rico, the Virgin Islands, Guam, and other U.S. Possessions. The word "domestic" is used also in conjunction with data and information that are compiled to characterize a particular segment or aspect of the uranium industry in the United States.

Domestic purchase: A uranium purchase from a firm located in the United States.

Domestic sale: A uranium sale to a firm located in the United States.

Domestic uranium industry: Collectively, those businesses (whether U.S. or foreign-based) that operate under the laws and regulations pertaining to the conduct of commerce within the United States and its territories and possessions and that engage in activities within the United States, its territories, and possessions specifically directed toward uranium exploration, development, mining, and milling; marketing of uranium materials; enrichment; fabrication; or acquisition and management of uranium materials for use in commercial nuclear power plants.

Enriched uranium: Uranium in which the ${ }^{235} \mathrm{U}$ isotope concentration has been increased to greater than the 0.711 percent ${ }^{235} \mathrm{U}$ (by weight) present in natural uranium.

Enrichment feed deliveries: Uranium that is shipped under contract to a supplier of enrichment services for use in preparing enriched uranium product to a specified ${ }^{235} \mathrm{U}$ concentration and that ultimately will be used as fuel in a nuclear reactor.

Enrichment services: (See Separative Work Units).

Exploration drilling: Drilling done in search of new mineral deposits, on extensions of known ore deposits, or at the location of a discovery up to the time when the company decides that sufficient ore reserves are present to justify commercial exploitation. Assessment drilling is reported as exploration drilling.

Fabricated fuel: Fuel assemblies composed of an array of fuel rods loaded with pellets of enriched uranium dioxide.

Floor price: A price specified in a market-price contracts as the lowest purchase price of the uranium, even if the market price falls below the specified price. The floor price may be related to the seller's production costs.

Foreign purchase: $A$ uranium purchase of foreign-origin uranium from a firm located outside of the United States.

Foreign sale: A uranium sale to a firm located outside the United States. 
Forward cost: The operating and capital costs still to be incurred in the production of uranium from in-place reserves. By using forward costing, estimates of reserves for ore deposits in differing geological settings and status of development can be aggregated and reported for selected cost categories. Included are costs for labor, materials, power and fuel, royalties, payroll taxes, insurance, and applicable general and administrative costs. Excluded from forward cost estimates are prior expenditures, if any, incurred for property acquisition, exploration, mine development, and mill construction, as well as income taxes, profit, and the cost of money. Forward costs are neither the full costs of production nor the market price at which the uranium, when produced, might be sold.

Heap leach solutions: The separation, or dissolving-out, from mined rock of the soluble uranium constituents by the natural action of percolating a prepared chemical solution through mounded (heaped) rock material. The mounded material usually contains low grade mineralized material and/or waste rock produced from openpit or underground mines. The solutions are collected after percolation is completed and processed to recover the valued components.

In situ leach mining (ISL): The recovery, by chemical leaching, of the valuable components of an orebody without physical extraction of the ore from the ground. Also referred to as "solution mining."

Long-term contract: One or more deliveries to occur after a period of at least 6 years following contract execution.

Market-related price: The prevailing price level in the market at a given time. It generally reflects a published spot price, is mutually agreed upon by the contracting parties, or is independently determined by an unbiased outside arbitrator.

Market-price contract: A contract in which the price of uranium is not specifically determined at the time the contract is signed but is based instead on the prevailing market price at the time of delivery. A market-price contract may include a floor price, that is, a lower limit on the eventual settled price. The floor price and the method of price escalation generally are determined when the contract is signed. The contract may also include a price ceiling or a discount from the agreed-upon market price reference.
Market-price settlement: The price paid for uranium delivery under a market-price contract. The price is commonly (but not always) determined at or sometime before delivery and may be related to a floor price, ceiling price, or discount.

Medium-term contract: One or more deliveries to occur over a period of 3 to 6 years following contract execution.

Milling of uranium: The processing of uranium from ore mined by conventional methods, such as underground or openpit methods, to separate the uranium from the undesired material in the ore.

National Uranium Resource Evaluation (NURE): A program begun by the U.S. Atomic Energy Commission (AEC) in 1974 to make a comprehensive evaluation of U.S. uranium resources and continued through 1983 by the AEC's successor agencies, the Energy Research and Development Administration (ERDA) and the Department of Energy (DOE). The NURE program included aerial radiometric and magnetic surveys, hydrogeochemical and stream sediment surveys, geologic drilling in selected areas, geophysical logging of selected boreholes, and geologic studies to identify and evaluate geologic environments favorable for uranium.

Nonconventional plant (uranium): A facility engineered and built principally for processing of uraniferous solutions that are produced during in situ leach mining, from heap leaching, or in the manufacture of other commodities, and the recovery, by chemical treatment in the plant's circuits, of uranium from the processed solutions.

Nuclear reactor: An apparatus in which a nuclear fission reaction, i.e., the splitting of atomic nuclei to release heat energy, can be initiated, controlled, and sustained at a specific rate. A reactor includes fuel (fissionable material), moderating materials to control the rate of fissioning, a heavy-walled pressure vessel to house reactor components, shielding to protect personnel, a system to conduct heat away from the reactor, and instrumentation for monitoring and controlling the reactor's systems.

Optional delivery commitment: A provision to allow the conditional purchase or sale of a specific quantity of material in addition to the firm quantity in the contract. 
Processing of uranium: The recovery of uranium from solutions produced by nonconventioanl mining methods, i.e., in situ leach mining (ISL), a byproduct of copper or phosphate mining, or heap leaching.

Reclamation: Process of restoring surface environment to acceptable pre-existing conditions. Includes surface contouring, equipment removal, well plugging, revegetation, etc.

Restoration: The returning of all affected groundwater to its premining quality for its premining use by employing the best practical technology.

Separative Work Units (SWU): The standard measure of enrichment services. The effort expended in separating a mass $F$ of feed of assay $x f$ into a mass $P$ of product assay $x p$ and waste of mass $W$ and assay $x w$ is expressed in terms of the number of separative work units needed, given by the expression $S W U=W V\left(x_{w}\right)+P V\left(x_{p}\right)-F V\left(x_{f}\right)$, where $V(x)$ is the "value function," defined as $V(x)=(1$ $2 \mathrm{x}) \ln ((1-\mathrm{x}) / \mathrm{x})$.

Short-term contract: One or more deliveries to occur over a period of less than 3 years following contract execution .

Spot contract: A one-time delivery of the entire contract to occur within one year of contract execution.

Spot market: Buying and selling of uranium for immediate or very near-term delivery. It typically involves transactions for delivery of up to 500,000 pounds $\mathrm{U}_{3} \mathrm{O}_{8}$ within a year of contract execution.

Spot-market price: A transaction price concluded "on the spot," that is, on a one-time, prompt basis. The transaction usually involves only one specific quantity of product. This contrasts with a term-contract sale price, which obligates the seller to deliver a product at an agreed frequency and price over an extended period.

Unfilled requirements: Requirements not covered by usage of inventory or supply contracts in existence as of January 1 of the survey year.

Uranium: A heavy, naturally radioactive, metallic element (atomic number 92). Its two principally occurring isotopes are ${ }^{235} \mathrm{U}$ and ${ }^{238} \mathrm{U}$. The isotope ${ }^{235} \mathrm{U}$ is indispensable to the nuclear industry because it is the only isotope existing in nature to any appreciable extent that is fissionable by thermal neutrons. The isotope ${ }^{238} \mathrm{U}$ is also important because it absorbs neutrons to produce a radioactive isotope that subsequently decays to the isotope ${ }^{239} \mathrm{Pu}$, which also is fissionable by thermal neutrons.

Uranium concentrate: A yellow or brown powder produced from naturally occurring uranium minerals as a result of milling uranium ore or processing uraniumbearing solutions. Synonymous with yellowcake, $\mathrm{U}_{3} \mathrm{O}_{8}$, or uranium oxide.

Uranium deposit: A discrete concentration of uranium mineralization that is of possible economic interest.

Uranium endowment: The uranium that is estimated to occur in rock with a grade of at least 0.01 percent $\mathrm{U}_{3} \mathrm{O}_{8}$. The estimate of the uranium endowment is made before consideration of economic availability and any associated uranium resources.

Uranium hexafluoride (UF $)$ : A white solid obtained by chemical treatment of $\mathrm{U}_{3} \mathrm{O}_{8}$ and which forms a vapor at temperatures above 56 degrees Centigrade. $\mathrm{UF}_{6}$ is the form of uranium required for the enrichment process.

Uranium ore: Rock containing uranium mineralization in concentrations that can be mined economically, (typically 1 to 4 pounds of $\mathrm{U}_{3} \mathrm{O}_{8}$ per ton or 0.05 to 0.20 percent $\mathrm{U}_{3} \mathrm{O}_{8}$ ).

Uranium oxide: Uranium concentrate or yellowcake. Abbreviated as $\mathrm{U}_{3} \mathrm{O}_{8}$.

Uranium property: A specific piece of land with uranium reserves that is held for the ultimate purpose of economically recovering the uranium. The land can be developed for production or undeveloped.

Uranium reserves: Estimated quantities of uranium in known mineral deposits of such size, grade, and configuration that the uranium could be recovered at or below a specified production cost with currently proven mining and processing technology and under current law and regulations. Reserves are based on direct radiometric and chemical measurements of drill holes and other types of sampling of the deposits. Mineral grades and thickness, 
spatial relationships, depths below the surface, mining and reclamation methods, distances to milling facilities, and amenability of ores to processing are considered in the evaluation. The amount of uranium in ore that could be exploited within the chosen forward-cost levels are estimated in accordance with conventional engineering practices.

Uranium resources categories: Three categories of uranium resources are used to reflect differing levels of confidence in the resources reported. Reasonably assured resources (RAR), estimated additional resources (EAR), and speculative resources (SR) are described below.

Reasonably assured resources ( $R A R$ ): The uranium that occurs in known mineral deposits of such size, grade, and configuration that it could be recovered within the given production cost ranges, with currently proven mining and processing technology. Estimates of tonnage and grade are based on specific sample data and measurements of the deposits and on knowledge of deposit characteristics. RAR correspond to DOE's uranium reserves category.

Estimated additional resources (EAR): The uranium in addition to RAR that is expected to occur, mostly on the basis of direct geological evidence, in extensions of well-explored deposits, little explored deposits, and undiscovered deposits believed to exist along well-defined geological trends with known deposits, such that the uranium can subsequently be recovered within the given cost ranges. Estimates of tonnage and grade are based on available sampling data and on knowledge of the deposit characteristics, as determined in the best-known parts of the deposit or in similar deposits. EAR correspond to DOE's probable potential resources category.

Speculative resources (SR): Uranium in addition to EAR that is thought to exist, mostly on the basis of indirect evidence and geological extrapolations, in deposits discoverable with existing exploration techniques. The locations of deposits in this category can generally be specified only as being somewhere within given regions or geological trends. The estimates in this category are less reliable than estimates of RAR and EAR. The category of SR corresponds to DOE's possible potential resources plus speculative potential resources categories combined.

Usage Agreement: Contracts held by enrichment customers that allow feed material to be stored at the enrichment plant site in advance of need.

Yellowcake: (See uranium oxide). 